Prepared in cooperation with Spokane County

\title{
Hydrogeology of the Little Spokane River Basin, Spokane, Stevens, and Pend Oreille Counties, Washington
}

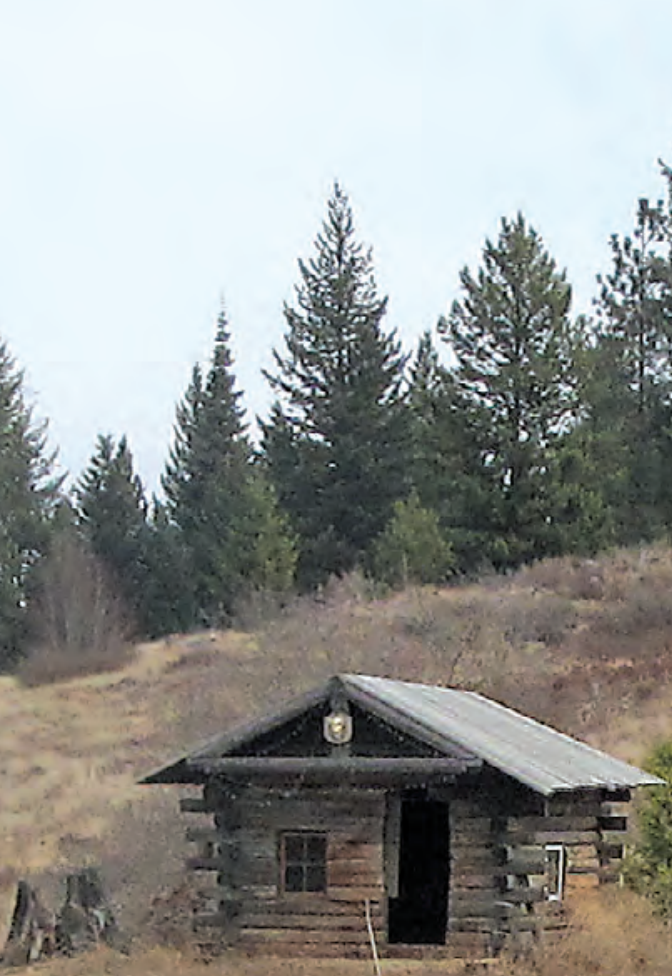

1. Scientific Investigations Report 2013-5124

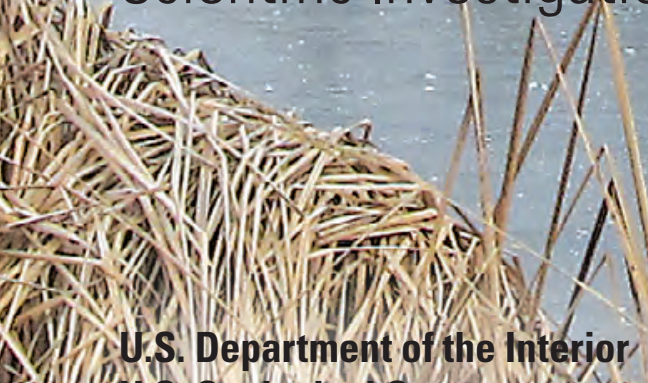

9. U. S. Department of the interior 1. Meological Survey Q VDav

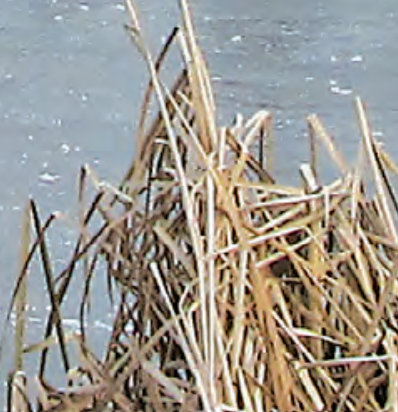

4. 15
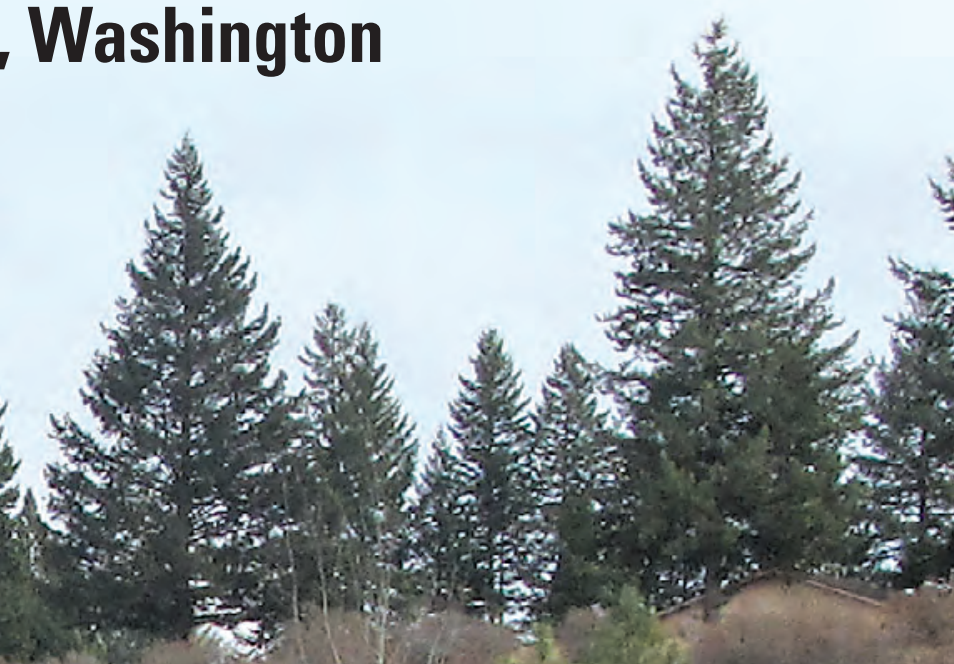
Cover: Photograph of area north of Spokane near Chattaroy, Washington, looking approximately northeast, autumn 2011. Photograph taken by Karen Payne, U.S.

Geological Survey. 


\section{Hydrogeology of the Little Spokane River Basin, Spokane, Stevens, and Pend Oreille Counties, Washington}

By Sue C. Kahle, Theresa D. Olsen, and Elisabeth T. Fasser

Prepared in cooperation with Spokane County

Scientific Investigations Report 2013-5124 


\title{
U.S. Department of the Interior SALLY JEWELL, Secretary
}

\section{U.S. Geological Survey \\ Suzette M. Kimball, Acting Director}

\author{
U.S. Geological Survey, Reston, Virginia: 2013
}

For more information on the USGS - the Federal source for science about the Earth, its natural and living resources, natural hazards, and the environment, visit http://www.usgs.gov or call 1-888-ASK-USGS.

For an overview of USGS information products, including maps, imagery, and publications, visit http://www.usgs.gov/pubprod

To order this and other USGS information products, visit http://store.usgs.gov

Any use of trade, firm, or product names is for descriptive purposes only and does not imply endorsement by the U.S. Government.

Although this information product, for the most part, is in the public domain, it also may contain copyrighted materials as noted in the text. Permission to reproduce copyrighted items must be secured from the copyright owner.

Suggested citation:

Kahle, S.C., Olsen, T.D., and Fasser, E.T., 2013, Hydrogeology of the Little Spokane River Basin, Spokane, Stevens, and Pend Oreille Counties, Washington: U.S. Geological Survey Scientific Investigations Report 2013-5124, 52 p., http:// pubs.usgs.gov/sir/2013/5124/ 


\section{Contents}

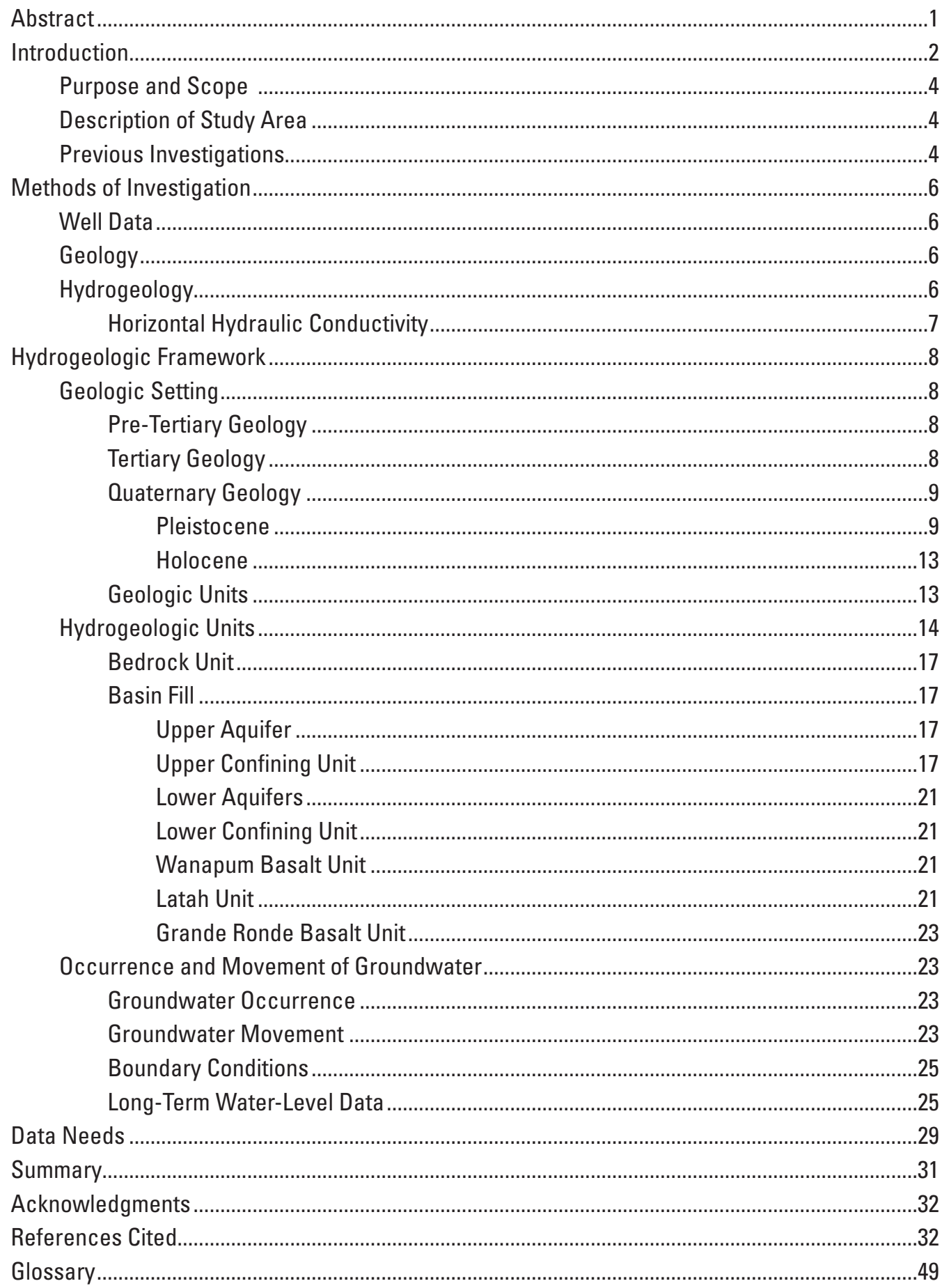




\section{Plates}

In pocket

1. Geologic map and location of project wells in the Little Spokane River Basin study area, Spokane, Stevens, and Pend Oreille Counties, Washington

2. Hydrogeologic unit map, unit of open interval of project wells, and hydrogeologic sections, Little Spokane River Basin, Spokane, Stevens, and Pend Oreille Counties, Washington

\section{Figures}

1. Map showing location of the Little Spokane River Basin study area, Spokane, Stevens, and Pend Oreille Counties, Washington ...

2. Map showing physiographic regions of Washington

3. Map showing extent of glacial ice and glacial lakes in northern Washington, Idaho, and parts of Montana

4. Conceptual model of the hydrogeologic system in the Little Spokane River Basin, Spokane, Stevens, and Pend Oreille Counties, Washington.

5. Map showing estimated altitude of the top of the bedrock in the Little Spokane River Basin, Spokane, Stevens, and Pend Oreille Counties, Washington

6. Map showing thickness of basin fill over bedrock in the Little Spokane River Basin, Spokane, Stevens, and Pend Oreille Counties, Washington.

7. Map showing thickness and areal extent, and water-level altitudes and inferred directions of groundwater flow of the Upper aquifer (UA) in the Little Spokane River Basin, Spokane, Stevens, and Pend Oreille Counties, Washington

8. Map showing thickness and areal extent, and water-level altitudes of the Lower aquifers (LA) in the Little Spokane River Basin, Spokane, Stevens, and Pend Oreille Counties, Washington

9. Map showing thickness and extent, and water-level altitudes and inferred directions of groundwater flow of the Grande Ronde basalt unit (B2) in the Little Spokane River Basin, Spokane, Stevens, and Pend Oreille Counties, Washington

10. Map showing water-level altitudes and inferred directions of groundwater flow in the Little Spokane River Basin, Spokane, Stevens, and Pend Oreille Counties, Washington

11. Map showing locations of wells with long-term water level measurements in the Little Spokane River Basin, Spokane, Stevens, and Pend Oreille Counties, Washington

12. Map showing Water Resource Inventory Area 55 in the Little Spokane River Basin, Spokane, Stevens, and Pend Oreille Counties, Washington. 


\section{Tables}

1. Geologic timescale with simplified geology of the Little Spokane River Basin study area, Spokane, Stevens, and Pend Oreille Counties, Washington.

2. Lithologic and hydrologic characteristics of the hydrogeologic units in the Little Spokane River Basin, Spokane, Stevens, and Pend Oreille Counties, Washington........16

3. Wells with long-term water level measurements in the Little Spokane River Basin, Spokane, Stevens, and Pend Oreille Counties, Washington

4. Selected physical and hydrologic data for the project wells in or near the Little Spokane River Basin, Spokane, Stevens, and Pend Oreille Counties, Washington.........36

\section{Conversion Factors, Datums, Abbreviations and Acronyms, and Well Numbering System}

\section{Conversion Factors}

Inch/Pound to SI

\begin{tabular}{|c|c|c|}
\hline Multiply & By & To obtain \\
\hline \multicolumn{3}{|c|}{ Length } \\
\hline inch (in.) & 2.54 & centimeter (cm) \\
\hline inch (in.) & 25.4 & millimeter (mm) \\
\hline foot $(\mathrm{ft})$ & 0.3048 & meter (m) \\
\hline mile (mi) & 1.609 & kilometer $(\mathrm{km})$ \\
\hline \multicolumn{3}{|c|}{ Area } \\
\hline acre & 4,047 & square meter $\left(\mathrm{m}^{2}\right)$ \\
\hline square mile $\left(\mathrm{mi}^{2}\right)$ & 2.590 & square kilometer $\left(\mathrm{km}^{2}\right)$ \\
\hline \multicolumn{3}{|c|}{ Volume } \\
\hline gallon (gal) & 3.785 & liter (L) \\
\hline gallon (gal) & 0.003785 & cubic meter $\left(\mathrm{m}^{3}\right)$ \\
\hline million gallons (Mgal) & 3,785 & cubic meter $\left(\mathrm{m}^{3}\right)$ \\
\hline cubic mile $\left(\mathrm{mi}^{3}\right)$ & 4.168 & cubic kilometer $\left(\mathrm{km}^{3}\right)$ \\
\hline \multicolumn{3}{|c|}{ Flow rate } \\
\hline foot per day (ft/d) & 0.3048 & meter per day $(\mathrm{m} / \mathrm{d})$ \\
\hline cubic foot per second $\left(\mathrm{ft}^{3} / \mathrm{s}\right)$ & 0.02832 & cubic meter per second $\left(\mathrm{m}^{3} / \mathrm{s}\right)$ \\
\hline cubic foot per day $\left(\mathrm{ft}^{3} / \mathrm{d}\right)$ & 0.02832 & cubic meter per day (m³/d) \\
\hline gallon per minute (gal/min) & 0.06309 & liter per second (L/s) \\
\hline \multicolumn{3}{|c|}{ Hydraulic gradient } \\
\hline foot per mile ( $\mathrm{ft} / \mathrm{mi})$ & 0.1894 & meter per kilometer \\
\hline \multicolumn{3}{|c|}{ Transmissivity* } \\
\hline square foot per day $\left(\mathrm{ft}^{2} / \mathrm{d}\right)$ & 0.09290 & square meter per day $\left(\mathrm{m}^{2} / \mathrm{d}\right)$ \\
\hline
\end{tabular}




\section{Conversion Factors, Datums, Abbreviations and Acronyms, and Well Numbering System}

Conversion Factors

SI to Inch/Pound

\begin{tabular}{rcc}
\hline Multiply & By & To obtain \\
\hline square meter $\left(\mathrm{m}^{2}\right)$ & Area & \\
\hline
\end{tabular}

Temperature in degrees Celsius $\left({ }^{\circ} \mathrm{C}\right)$ may be converted to degrees Fahrenheit $\left({ }^{\circ} \mathrm{F}\right)$ as follows:

$$
{ }^{\circ} \mathrm{F}=\left(1.8 \mathrm{x}^{\circ} \mathrm{C}\right)+32
$$

*Transmissivity: The standard unit for transmissivity is cubic foot per day per square foot times foot of aquifer thickness [(ft $\left.\left.\mathrm{t}^{3} / \mathrm{d}\right) / \mathrm{ft}^{2}\right] \mathrm{ft}$. In this report, the mathematically reduced form, foot squared per day $\left(\mathrm{ft}^{2} / \mathrm{d}\right)$, is used for convenience.

Datums

Vertical coordinate information is referenced to the North American Vertical Datum of 1988 (NAVD 88).

Horizontal coordinate information is referenced to the North American Datum of 1983 (NAD 83).

Altitude, as used in this report, refers to distance above the vertical datum.

Abbreviations and Acronyms

$\begin{array}{ll}\text { BR } & \text { Bedrock unit } \\ \text { B1 } & \text { Wanapum Basalt unit } \\ \text { B2 } & \text { Grande Ronde Basalt unit } \\ \text { LA } & \text { Lower aquifers unit } \\ \text { LC } & \text { Lower confining unit } \\ \text { LT } & \text { Latah unit } \\ \text { NED } & \text { National Elevation Dataset } \\ \text { UA } & \text { Upper aquifer } \\ \text { UC } & \text { Upper confining unit } \\ \text { USGS } & \text { U.S. Geological Survey }\end{array}$




\title{
Conversion Factors, Datums, Abbreviations and Acronyms, and Well Numbering System
}

\author{
Well Numbering System
}

In Washington, wells are assigned numbers that identify their location in a township, range, section, and 40-acre tract. For example, well number 28N/41E-14A05D1 indicates that the well is in township 28 north of the Willamette Base Line, and range 41 east of the Willamette Meridian. The numbers immediately following the hyphen indicate the section (14) in the township, and the letter following the section (A) gives the 40 -acre tract of the section. The two-digit sequence number (05) following the letter indicates that the well was the fifth one inventoried in that 40 -acre tract. The "D" following the sequence number indicates that the well has been deepened. In the illustrations of this report, wells are identified individually using only the section and 40 -acre tract, such as 14A05D1. The townships and ranges are shown on the map borders.

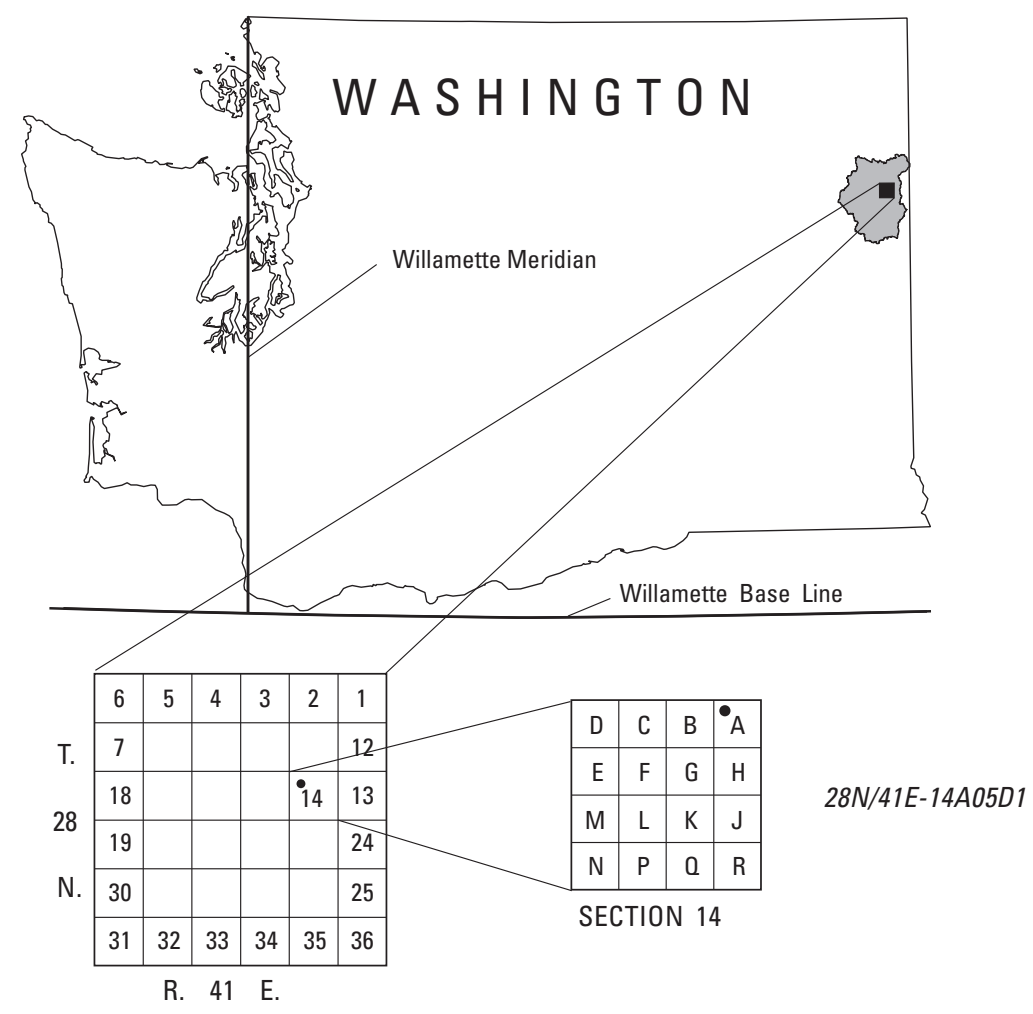

Well numbering system in Washington. 
This page intentionally left blank. 


\title{
Hydrogeology of the Little Spokane River Basin, Spokane, Stevens, and Pend Oreille Counties, Washington
}

\author{
By Sue C. Kahle, Theresa D. Olsen, and Elisabeth T. Fasser
}

\section{Abstract}

A study of the hydrogeologic framework of the Little Spokane River Basin was conducted to identify and describe the principal hydrogeologic units in the study area, their hydraulic characteristics, and general directions of groundwater movement. The Little Spokane River Basin includes an area of 679 square miles in northeastern Washington State covering parts of Spokane, Stevens, and Pend Oreille Counties. The groundwater system consists of unconsolidated sedimentary deposits and isolated, remnant basalt layers overlying crystalline bedrock. In 1976, a water resources program for the Little Spokane River was adopted into rule by the State of Washington, setting instream flows for the river and closing its tributaries to further uses. Spokane County representatives are concerned about the effects that additional groundwater development within the basin might have on the Little Spokane River and on existing groundwater resources. Information provided by this study will be used in future investigations to evaluate the effects of potential increases in groundwater withdrawals on groundwater and surface-water resources in the basin.

The hydrogeologic framework consists of eight hydrogeologic units: the Upper aquifer, Upper confining unit, Lower aquifers, Lower confining unit, Wanapum basalt unit, Latah unit, Grande Ronde basalt unit, and Bedrock. The Upper aquifer is composed mostly of sand and gravel and varies in thickness from 4 to $360 \mathrm{ft}$, with an average thickness of $70 \mathrm{ft}$. The aquifer is generally finer grained in areas farther from main outwash channels. The estimated horizontal hydraulic conductivity ranges from 4.4 to 410,000 feet per day (ft/d), with a median hydraulic conductivity of $900 \mathrm{ft} / \mathrm{d}$. The Upper confining unit is a low-permeability unit consisting mostly of silt and clay, and varies in thickness from 5 to $400 \mathrm{ft}$, with an average thickness of $100 \mathrm{ft}$. The estimated horizontal hydraulic conductivity ranges from 0.5 to $5,600 \mathrm{ft} / \mathrm{d}$, with a median hydraulic conductivity of $8.2 \mathrm{ft} / \mathrm{d}$. The Lower aquifers unit consists of localized confined aquifers or lenses consisting mostly of sand that occur at depth in various places in the basin; thickness of the unit ranges from 8 to $150 \mathrm{ft}$, with an average thickness of $50 \mathrm{ft}$. The Lower confining unit is a low-permeability unit consisting mostly of silt and clay; thickness of the unit ranges from 35 to $310 \mathrm{ft}$, with an average thickness of $130 \mathrm{ft}$.

The Wanapum basalt unit includes the Wanapum Basalt of the Columbia River Basalt Group, thin sedimentary interbeds, and, in some places, overlying loess. The unit occurs as isolated remnants on the basalt bluffs in the study area and ranges in thickness from 7 to $140 \mathrm{ft}$, with an average thickness of $60 \mathrm{ft}$. The Latah unit is a mostly low-permeability unit consisting of silt, clay, and sand that underlies and is interbedded with the basalt units. The Latah unit ranges in thickness from 10 to $700 \mathrm{ft}$, with an average thickness of $250 \mathrm{ft}$. The estimated horizontal hydraulic conductivity ranges from 0.19 to $15 \mathrm{ft} / \mathrm{d}$, with a median hydraulic conductivity of $0.56 \mathrm{ft} / \mathrm{d}$. The Grande Ronde unit includes the Grande Ronde Basalt of the Columbia River Basalt Group and sedimentary interbeds. Unit thickness ranges from 30 to $260 \mathrm{ft}$, with an average thickness of $140 \mathrm{ft}$. The estimated horizontal hydraulic conductivity ranges from 0.03 to $13 \mathrm{ft} / \mathrm{d}$, with a median hydraulic conductivity of $2.9 \mathrm{ft} / \mathrm{d}$.

The Bedrock unit is the only available source of groundwater where overlying sediments are absent or insufficiently saturated. The estimated horizontal hydraulic conductivity ranges from 0.01 to $5,000 \mathrm{ft} / \mathrm{d}$, with a median hydraulic conductivity of $1.4 \mathrm{ft} / \mathrm{d}$. The altitude of the buried bedrock surface ranges from about 2,200 ft to about 1,200 ft.

Groundwater movement in the Little Spokane River Basin mimics the surface-water drainage pattern of the basin, moving from the topographically high tributary-basin areas toward the topographically lower valley floors. Water-level altitudes range from more than 2,700 ft to about 1,500 ft near the basin's outlet. 


\section{Introduction}

The Little Spokane River Basin, also referred to as the Little Spokane Water Resources Inventory Area 55 (WRIA 55), includes an area of $679 \mathrm{mi}^{2}$ in northeastern Washington State covering parts of Spokane, Stevens, and Pend Oreille Counties (fig. 1). Streams originate in the northern part of the basin and contribute flow to the Little Spokane River, which flows southward about 49 mi from just south of Newport, Washington, to its confluence with the Spokane River, about $5 \mathrm{mi}$ northwest of the City of Spokane. Mean annual flow in the Little Spokane River at Dartford (U.S. Geological Survey (USGS) streamgaging station No. 12431000; fig. 1) is $299 \mathrm{ft}^{3} / \mathrm{s}$ (U.S. Geological Survey, 2009).

Important aquifers in the basin occur primarily within unconsolidated sediments that include glacial flood deposits and recent alluvium. Basalt aquifers also contribute water to some wells in the southern part of the basin where the basalt underlies the unconsolidated sediment or occurs at land surface in remnant basalt mesas. Crystalline basement rocks provide generally limited quantities of water in the higher elevation areas of the basin where the other more-productive units do not occur. The Spokane Valley-Rathdrum Prairie aquifer, a large regional groundwater system described by Kahle and Bartolino (2007) and Hsieh and others (2007), occupies a small area of the southern part of the basin (fig. 1).

Precipitation in the Little Spokane River Basin is relatively low, particularly during summer and early autumn. The annual precipitation in the basin ranges from $17 \mathrm{in} / \mathrm{yr}$ at its confluence with the Spokane River to $40 \mathrm{in} / \mathrm{yr}$ in the higher altitude areas (Washington State Department of Ecology, 2012); average precipitation at Deer Park is 22 in. (Chung, 1975). The basin relies on spring snowmelt from the higher altitude areas of the basin and groundwater discharge to the river to maintain streamflows during the drier months, typically July through October.

In 1976, a water resources program for the Little Spokane River was adopted into rule, setting instream flows for the river and closing its tributaries, as well as natural lakes, to further uses (Washington State Department of Ecology, 1988). Instream flow rules establish a water right and priority date for the river to protect instream uses like fish habitat, water quality, recreation, and navigation. The rule only affects those who apply for new water rights after the rule was adopted. These "junior" water rights can be shut off when the flow in the river is less than required flows. Currently, the streamgage at Dartford is used to manage all junior water rights in the Little Spokane River; when summer flow at Dartford is less than the minimum $115 \mathrm{ft}^{3} / \mathrm{s}$, all junior water rights holders in the basin receive notice to stop withdrawals (Spokane County, 2006). Residents on the Little Spokane River have been advised to conserve water in 9 of the last 10 years when late summer flows have diminished enough to restrict junior water-right holders and other users from taking water from the river. Specifically, about 150 junior water-right holders and other residents along the Little Spokane River have been asked to curtail their irrigation or other use of river water during summer low flows to ensure that water is available for instream resources and senior water-right holders.

Although parts of the hydrogeologic framework had been studied prior to this investigation (Cline, 1969; EMCON, 1992; Dames and Moore, Inc., 1995; Boese, 1996; and Golder Assoc., Inc., 2003), the nature and extent of the unconsolidated sediments and basalt throughout the basin were not well defined. Additionally, Golder Assoc., Inc. (2003) observed that the Diamond Lake area in the northeastern part of the basin might be a conduit for groundwater flow from the Pend Oreille River Basin into the headwaters of the Little Spokane River. An assessment of the hydrogeologic framework of the entire basin was needed, prior to and as a basis for developing a groundwater flow model that could in turn quantify the effects of groundwater use on the groundwater and surface-water system.

Spokane County representatives are concerned about the effects of potential future groundwater development throughout the basin. With increased subdivision and development, an increase in exempt groundwater use is expected to continue, but the potential effects of this growth on the Little Spokane River and the basin's aquifers are not known.

To obtain information necessary to evaluate these concerns, Spokane County requested that the USGS conduct this initial study with the primary goal of describing the hydrogeologic framework of the Little Spokane River Basin. This work is intended to be followed by subsequent studies that would provide the remaining information needed for the eventual construction and calibration of a numerical groundwater flow model. Such a model then could be used by the county to evaluate the possible regional effects of different groundwater-use and climate scenarios on the groundwater and surface-water system of the basin. 


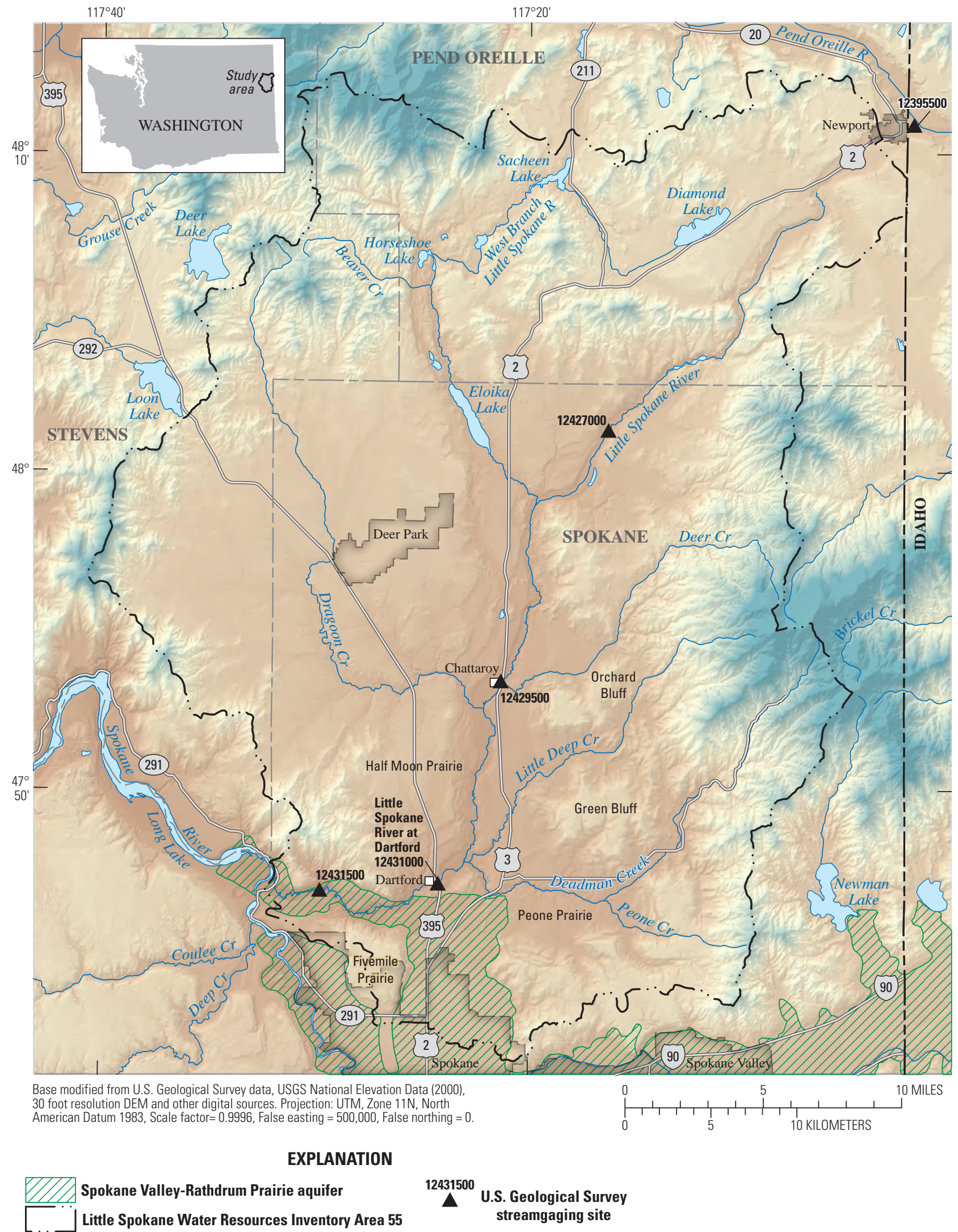

Figure 1. Location of the Little Spokane River Basin study area, Spokane, Stevens, and Pend Oreille Counties, Washington. 


\section{Purpose and Scope}

This report describes the development of a hydrogeologic framework of the Little Spokane River Basin, focusing on the area upstream of the Little Spokane River at Dartford (USGS Station No. 12431000). The framework is based on a review and interpretation of available drillers' logs for wells in the basin, existing geologic maps, previous investigations, and data collected at field-located wells. The description of the framework includes:

1. An updated and compiled digital geologic map for the entire basin,

2. A map and sections of the major hydrogeologic units,

3. Estimates of horizontal hydraulic conductivity by hydrogeologic unit,

4. Thickness and extent maps of principal water-bearing units,

5. A map of the approximate bedrock surface that marks the lower boundary of the basin's aquifer system,

6. Maps of water-level altitudes based on measurements made from November through December 2011 with inferred directions of groundwater movement, and

7. A map and table of long-term water-level measurement sites in the basin.

The report also includes a brief description of the regional and local geologic history of the Little Spokane River Basin. A glossary is included with definitions for selected technical terms contained in the report.

\section{Description of Study Area}

The Little Spokane River Basin is in the Okanogan Highlands East, a physiographic region east of the Columbia River and Franklin D. Roosevelt Lake, and north of the Columbia Plateau (fig. 2). This area is characterized by north-south trending mountain ranges reaching altitudes of $8,000 \mathrm{ft}$ separated by valleys. Rock types in the study area include the oldest sedimentary and metamorphic rocks in Washington State (Lasmanis, 1991), younger granites, and even younger basalt. Today, remaining basalt in the study area forms mesas in the southern part of the Little Spokane River Basin.

The major tributaries to the Little Spokane River are Deadman, Deer, Dragoon, and Little Deep Creeks, as well as the West Branch of the Little Spokane River; the largest lakes include Diamond, Eloika, Horseshoe, and Sacheen, which are all located in the northern part of the basin (fig. 1). Altitudes range from more than $5,300 \mathrm{ft}$ in the northeast side of the basin to about 1,540 $\mathrm{ft}$ at the confluence of the Little Spokane and Spokane Rivers.
Evergreen forests are the primary land cover in the mountainous northern and eastern parts of the basin. Agricultural lands are interspersed throughout the basin, but most are in the lower-elevation, southeastern parts of the basin. Urban areas are most prominent in the southern part of the basin and include the northern extent of the City of Spokane. Smaller cities in the basin include Deer Park and Newport (fig. 1). Numerous vacation or seasonal properties are located near the many lakes in the study area.

\section{Previous Investigations}

Numerous documents describe previous investigations that have contributed to the understanding of the hydrogeologic framework in all, or parts, of the Little Spokane River Basin. These documents are listed below, in chronological order.

Cline (1969) studied the groundwater resources and related geology of an area covering $450 \mathrm{mi}^{2}$ in north-central Spokane and southeastern Steven Counties. The report includes descriptions of geologic units and their water-bearing properties and groundwater recharge, discharge, availability, chemical quality, and use.

The Washington State Department of Ecology outlined management policies in the Little Spokane River Basin in Chung (1975). The policies in the document provided a process for making water-allocation and water-use decisions within the basin. The program established base flows necessary for preserving in-stream values, declared beneficial use priorities, closed certain surface-water bodies to further appropriation, allocated public water, and set forth water-resources administrative procedures.

Landau Associates (1991) characterized the hydrogeologic conditions and contaminant distribution at the Colbert Landfill, an inactive 40 -acre municipal solid waste landfill located about $15 \mathrm{mi}$ north of Spokane, Washington. Their activities were conducted in order to obtain design information needed to design a groundwater pump and treat system for the site.

EMCON (1992) described geologic, hydrogeologic, and groundwater quality information for the Deer Park Basin, an area of about $46 \mathrm{mi}^{2}$, in northern Spokane County. Topics in the report include geologic history, geologic units, occurrence and movement of groundwater, water rights, nitrates in groundwater, stream gaging, and a hydrologic budget for the area.

Dames and Moore, Inc. (1995) assessed the status of the surface and groundwater resources in the Little Spokane River Basin (WRIA 55) in support of regulatory concerns and water management decisions. Based on available data, hydrologic assessments were made that included water quantity, hydrogeology, water demand, water quality, and status of aquatic habitat and fish stocks. 


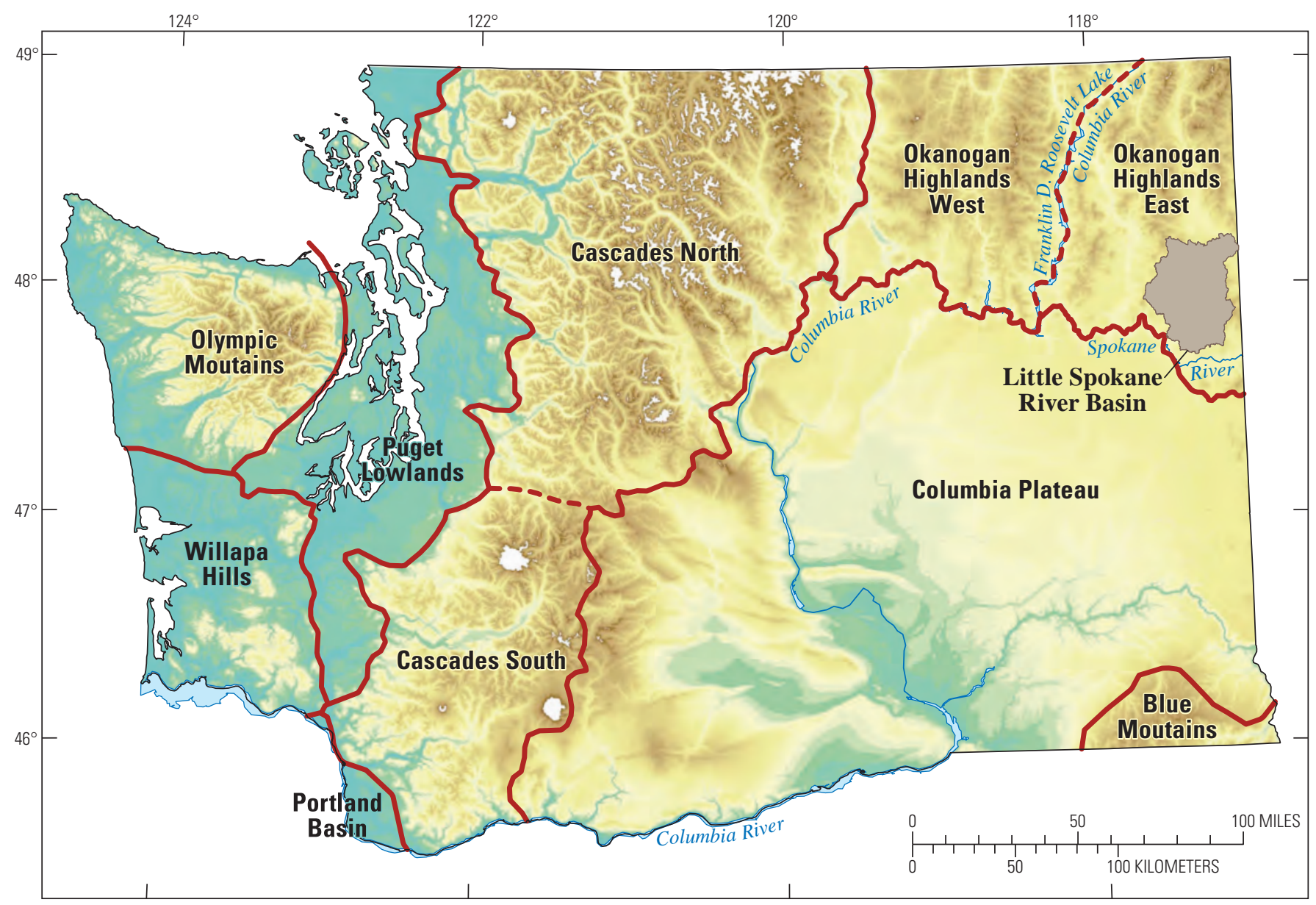

Figure 2. Physiographic regions of Washington. (Modified from Lasmanis, 1991.)

Ader (1996) examined the spatial distribution of wells and constructed a conceptual hydrogeologic model of the 4-mi ${ }^{2}$ Green Bluff Plateau in response to reported water-level declines and well interference issues. The study, conducted by the Washington State Department of Ecology, was done in support of an evaluation of water rights applications on the plateau.

Boese (1996) completed a Master's thesis on aquifer delineation and baseline groundwater quality in a $230-\mathrm{mi}^{2}$ area covering most of the southern half of the Little Spokane River Basin. The thesis includes descriptions of the geologic and hydrogeologic setting and water quality sampling, methods, and results.

Boleneus and Derkey (1996) described the geohydrology of a 12-mi ${ }^{2}$ area of Peone Prairie based on drilling and geophysical tests made in the late 1970s as part of a mineral exploration venture. Their work includes descriptions of aquifers and confining units found during the explorations.
Golder Assoc., Inc. (2003) described the surface water, groundwater, water quality, water rights, and water use in the Little Spokane (WRIA 55) and Middle Spokane (WRIA 57) basins as part of watershed planning efforts. The combined area includes $960 \mathrm{mi}^{2}, 675 \mathrm{mi}^{2}$ in the Little Spokane River Basin, and $285 \mathrm{mi}^{2}$ in the Middle Spokane Basin. Based on the data compilation and analysis effort, Golder Assoc., Inc. (2004) constructed a watershed simulation model for the combined Little and Middle Spokane watershed.

The southernmost part of the Little Spokane River Basin, near north Spokane, overlaps with a small part of the Spokane Valley-Rathdrum Prairie aquifer, which was described in a series of reports including Campbell (2005), Kahle and others (2005), Kahle and Bartolino (2007), Bartolino (2007), and Hsieh and others (2007). These reports include descriptions of the hydrogeologic framework, water-level maps, water budget components, and a computer flow model of the aquifer to be used in the management of the Spokane Valley-Rathdrum Prairie aquifer. 
Spokane County Water Resources has produced several documents that describe groundwater inventory and mapping in the Little Spokane River Basin (Spokane County, 2009), residential water use in Spokane County (2010a), and groundwater altitude and stream flow monitoring in the Little Spokane River Basin (2010b, 2011). The Spokane County Conservation District (2010) produced a stream-gage report for Deadman and Dragoon Creeks and the west branch of the Little Spokane River. As of 2012, streamflow measurements in the basin are made by USGS, Spokane Conservation District, and Spokane Community College.

\section{Methods of Investigation}

Collecting the basic data required to characterize the hydrogeologic framework and estimate the direction of groundwater movement in the Little Spokane River Basin involved a field inventory of wells, measurement of water levels in wells, and construction of hydrogeologic sections, hydrogeologic unit maps, and water-level maps.

\section{Well Data}

Between November and December 2011, 317 wells throughout the study area were field located to acquire lithologic data and to measure the depth to water in wells. Criteria for site selection included availability of a driller's report and lithologic information (obtained from well records at the USGS Washington Water Science Center and the Washington State Department of Ecology), location and depth of the well, and the ease of access to the well. The intent was to collect data from wells evenly distributed throughout the study area. This was not possible in all areas because of lack of development in much of the basin, or lack of permission to access some wells.

To further augment the project data set, 95 non-fieldlocated wells were assigned approximate locations (latitude and longitude coordinates) using public land survey locations (township, range, section, and quarter-quarter section), well addresses, and (or) parcel numbers for each well included on drillers' logs. To the extent possible, paper maps (USGS $71 / 2$-minute quadrangles and City or County road maps) and on-line maps (Google ${ }^{\mathrm{TM}}$ Earth, 2011; Pend Oreille County Assessor, 2011; Spokane County Assessor, 2011; and Stevens County Assessor, 2011) were used to verify drillers' locations and to estimate latitude and longitude for the non-field-located wells. Locations of all 412 project wells are shown on plate 1 , and selected physical and hydrologic data for the wells are provided in table 4 (at back of report).
Information gathered at project wells included site location and well-construction details. Depth to water (water level) was measured in most wells using an electric tape or graduated steel tape, both with accuracy to $0.01 \mathrm{ft}$. In some cases, water levels were not measured because a well was difficult to access. Out of the 317 field inventoried wells, 220 wells had a measurable water level. One well was observed as flowing, meaning the water level was above the land surface altitude. Latitude and longitude were obtained for field-located wells using a Global Positioning System receiver with a horizontal accuracy of one-tenth of a second (about 10 $\mathrm{ft}$ ). Land-surface altitude for each project well was obtained from a digital elevation model with 10-m square cells using the latitude and longitude for each well. All water-level measurements were made by USGS personnel according to standardized techniques of the USGS (Drost, 2005). Information for all project wells was entered into the USGS National Water Information System database.

\section{Geology}

The geologic map of the study area (pl. 1) was compiled and simplified from several sources, including the digital geologic map database (1:100,000 scale) for Washington (Washington Division of Geology and Earth Resources, 2005), a spatial database for the geology of the Northern Rocky Mountains developed by Zientek and others (2005), the surficial geologic map of the Chewelah 1:100,000 quadrangle (Carrara and others, 1995), and the reconnaissance geologic map of the north-central Spokane and southeastern Stevens Counties (Cline, 1969). In some areas, modifications were made to existing maps based on field visits or stratigraphic evidence obtained during this investigation, primarily from drillers' logs for field-located water wells.

\section{Hydrogeology}

Lithologic data from the field-inventoried wells were entered into the Rockworks $2006^{\circledR}$ software, a stratigraphic analysis package. Nine hydrogeologic sections were constructed using Rockworks to identify and correlate eight hydrogeologic units, primarily on the basis of grain size and stratigraphic position. Thickness and extent-of-unit maps were manually drawn for three units using information from the hydrogeologic sections and data from the remaining project wells. 


\section{Horizontal Hydraulic Conductivity}

Hydraulic conductivity is a measure of a material's ability to transmit water. Horizontal hydraulic conductivity was estimated for the hydrogeologic units using the drawdown/ discharge relation reported on drillers' logs that reported pump testing wells for 1-29 hours. Only data from those wells with a driller's log containing discharge rate, duration of pumping, drawdown, static water level, well-construction data, and lithologic log were used. Estimates of horizontal hydraulic conductivity for this study area are presented in the section "Hydrogeologic Units." Estimates made for neighboring basins and for similar units, using the same methods described here, are available in Kahle and others, 2003, 2010.

Two methods were used to estimate hydraulic conductivity, depending on well construction. For data from wells with a screened or perforated interval, the modified Theis equation (Ferris and others, 1962) was first used to estimate transmissivity of the pumped interval. Transmissivity is the product of horizontal hydraulic conductivity and thickness of the hydrogeologic unit supplying water to the well.

The modified equation is

$$
s=\frac{Q}{4 \pi T} \ln \frac{2.25 T t}{r^{2} s}
$$

where

$$
\begin{aligned}
& s \quad= \text { drawdown in the well, in feet; } \\
& Q \quad= \text { discharge, or pumping rate, of the well, } \\
& \text { in cubic feet per day; } \\
& T \quad= \text { transmissivity of the hydrogeologic unit, in } \\
& \text { square feet per day; } \\
& t \quad= \text { length of time the well was pumped, in } \\
& \text { days; } \\
& r \quad= \text { radius of the well, in feet; and } \\
& S \quad= \text { storage coefficient, a dimensionless } \\
& \quad \text { number, assumed to be } 0.0001 \text { for } \\
& \quad \text { confined units and } 0.1 \text { for unconfined } \\
& \text { units. }
\end{aligned}
$$

Assumptions for using equation 1 are that aquifers are homogeneous, isotropic, and infinite in extent; wells are fully penetrating; flow to the well is horizontal; and water is released from storage instantaneously. Additionally, for unconfined aquifers, drawdown is assumed to be small in relation to the saturated thickness of the aquifer. Although many of the assumptions are not precisely met, the field conditions in the study area approximate most of the assumptions.

A computer program was used to solve equation 1 for transmissivity $(T)$ using Newton's iterative method (Carnahan and others, 1969). The calculated transmissivity values were not sensitive to assumed storage coefficient values; the difference in computed transmissivity between using 0.1 and 0.0001 for the storage coefficient is a factor of only about 2 .
The following equation was used to calculate horizontal hydraulic conductivity from the calculated transmissivity:

$$
K_{h}=\frac{T}{b}
$$

where

$$
\begin{gathered}
K_{h}=\begin{array}{l}
\text { horizontal hydraulic conductivity of the } \\
\text { geologic material near the well opening, } \\
\text { in feet per day; and }
\end{array} \\
b \quad \begin{array}{l}
\text { thickness, in feet, approximated using the } \\
\text { length of the open interval as reported in } \\
\text { the driller's report. }
\end{array}
\end{gathered}
$$

The use of the length of a well's open interval for $b$ overestimates values of $K_{h}$ because the equations assume that all the water flows horizontally within a layer of this thickness. Although some of the flow will be outside this interval, the amount may be relatively small because in most sedimentary deposits, vertical flow is inhibited by layering.

For data from wells having only an open-ended casing (no perforations), a second equation was used to estimate hydraulic conductivities. Bear (1979) provides an equation for hemispherical flow to an open-ended well just penetrating a hydrogeologic unit. When modified for spherical flow to an open-ended well within a unit, the equation becomes

$$
K_{h}=\frac{Q}{4 \pi s r}
$$

Equation 3 is based on the assumption that horizontal and vertical hydraulic conductivities are equal, which is not likely for the deposits in the study area. The result of violating this assumption is underestimating $K_{h}$ by an unknown amount.

The resulting estimates of hydraulic conductivity using the methods described above are presented in the Hydrogeologic Units section. The median values of estimated hydraulic conductivities for the aquifers are similar in magnitude to values reported by Freeze and Cherry (1979, p. 29) for similar materials. It is recognized that the estimates are biased toward the more productive zones in these units and may not be representative of the entire unit. The minimum hydraulic conductivities for the hydrogeologic units illustrate that there are zones of low hydraulic conductivity in most units. Additionally, the range of hydraulic conductivities is at least three orders of magnitude for most units, indicating substantial heterogeneity and inherent uncertainty in estimating hydraulic conductivity. Although many uncertainties are in the estimated values of hydraulic conductivity, these estimates provide an initial assessment of the relative differences in hydraulic conductivity between the different hydrogeologic units. These relative differences provide the basis for an initial conceptual model of hydraulic conductivity values to be used in future computer modeling. 


\section{Hydrogeologic Framework}

This section describes the geologic and hydrogeologic framework, including the physical, lithologic, and hydrologic characteristics of the hydrogeologic units that compose the groundwater system of the Little Spokane River Basin. An understanding of the geologic setting and relation of geologic units is required to understand the hydrogeologic framework and describe the occurrence and availability of groundwater within the watershed.

\section{Geologic Setting}

A description of the geologic events that have defined the geologic framework in the study area is provided in the following section. Although descriptions of the region's geologic history are available at various levels of detail in numerous documents, the summary that follows is based in part on descriptions contained in Cline (1969), Carrara and others (1995, 1996), Boese (1996), Kiver and Stradling (2001), Kahle and Bartolino (2007), and Bjornstad and Kiver (2012).

The geologic history presented in this report describes three major time periods: the pre-Tertiary, the Tertiary, and the Quaternary. An expanded description of the geologic history for each of these time periods is presented below. A simplified geologic time scale (table 1) is provided to aid the reader in understanding the sequence of geologic events and the magnitude of geologic time during which they occurred. Eleven geologic map units occur in the Little Spokane River Basin; they are described below and are shown on plate 1 .

\section{Pre-Tertiary Geology}

The oldest rocks in the region surrounding and underlying the study area are metamorphosed, fine-grained sediments that originally were deposited in a large, shallow north-south-trending marine basin during the Precambrian (table 1). These rocks are present in outcrop today as low-grade metasedimentary rocks, including argillite, siltite, and quartzite, which grade locally into more highly metamorphosed schists and gneisses. In the study area, these rocks occur in the headwater areas of the Little Spokane River Basin northwest of Eloika Lake, as well as forming an eastwest-trending ridge of mountains (Bare and Lone Mountains and Mt. Pisgah) between Diamond Lake to the north, and Chain Lakes and Elk to the south (p€m, pl. 1).

Following deposition and metamorphism, as much as 20,000 $\mathrm{ft}$ of the Precambrian rocks were eroded before the Paleozoic Era began (Conners, 1976). During the Paleozoic, additional sedimentation occurred in shallow seas that resulted in shale, limestone, and sandstone being deposited over the Precambrian rocks. However, from near the end of the Paleozoic to the present, the region mostly has been emergent, and much of the post-Cambrian sediments have been eroded from the area leaving few surface exposures. Small outcrops occur just outside the Little Spokane River Basin northwest of Loon and Deer Lakes.

Emplacement of various granitic intrusive bodies, along with associated metamorphism and deformation, occurred during a long period of time between the Jurassic and Tertiary. The largest volume of granitic rocks was emplaced during the Cretaceous and includes biotite-muscovite (two-mica) granite that forms Dunns and Lookout Mountains on the southwest part of the study area and the southern end of the Selkirk Mountains, including Mt. Spokane, on the eastern side of the basin (Stoffel and others, 1991). Much smaller outcrops of Cretaceous biotite granite form Dart Hill and the northern side of Fivemile Prairie (Boese, 1996). Younger granitic rocks (hornblende-biotite monzogranite and granodiorite), emplaced during the Eocene, occur in the north part of the study area in the Diamond and Sacheen Lake areas, and on the western margin of the basin south of Loon Lake (Miller, 2000).

All granitic rocks that occur in the study area are included in one geologic map unit, TKg (pl. 1). This unit occurs at land surface throughout much of the study area and comprises most of the highland areas along the perimeter of the basin. Numerous water wells are completed in granite where it occurs at land surface, or where overlying units are thin and (or) poorly saturated.

\section{Tertiary Geology}

During the Miocene Epoch, basalt lava flowed from fissures and vents in eastern Washington, northeastern Oregon, and western Idaho, mantling much of the pre-existing landscape and filling in low-lying areas. By the end of the Miocene, five formations of the Columbia River Basalt Group covered much of eastern Washington, west-central Idaho, and northeastern Oregon. Burns and others (2011) estimated that more than $42,000 \mathrm{mi}^{2}$ were covered with a volume of about $34,000 \mathrm{mi}^{3}$ of basalt and associated sedimentary interbeds. Because the study area is on the northeastern edge of the Columbia Plateau (fig. 2), only a few flows of two formations of the Columbia River Basalt Group reached the area. The oldest flows in the area are part of the Grande Ronde Formation. The stratigraphically higher and younger flows are part of the Wanapum Formation (pl. 1).

The Grande Ronde Basalt underlies Wild Rose and Half Moon Prairies, and other areas west of the Little Spokane River (pl. 1; pl. 2, sections $C-C^{\prime}, D-D^{\prime}$, and $E-E^{\prime}$ ). Boese (1996) identified a thin layer of Grande Ronde Basalt in one deep well in section 19 of T. 27 N., R 44 E. near the western edge of Green Bluff. Other deep wells on Green Bluff, however, did not encounter Grande Ronde Basalt (Boese, 
1996). The Wanapum Formation has fewer occurrences in the study area than the Grande Ronde because much of it has been eroded away. Where it remains, it forms basalt mesas or bluffs including Green Bluff, Orchard Bluff, Pleasant Prairie, Orchard Prairie, and Fivemile Prairie.

During the Miocene, as lava flows entered the area, basalt blocked existing drainages to the southwest and caused the formation of lakes and swamps that covered the lowlands of large areas surrounding the basalt flows (Boese, 1996). During pauses in the eruption and flow of basalt, great thicknesses of sand, silt, and clay were deposited in large basalt-dammed lakes along the perimeter of the flows. In the study area, the resulting deposits are known as the Latah Formation. Repeated cycles of basalt flows and continued damming of the stream network resulted in interlayered sediment and basalt.

Following the eruption history of the Columbia River Basalt Group, and emplacement of numerous flows and the Latah Formation, a period of slow downcutting from the Late Miocene to the Early Pleistocene removed as much as $590 \mathrm{ft}$ of Latah Formation from the region (Anderson, 1927). Streams in the redeveloping drainages eroded much of the exposed Latah Formation and some of the younger basalt near their margin. Accurate estimates of the thickness and extent of the remaining Latah Formation sediments are difficult to determine because of the cover of Pleistocene drift and the difficulty in distinguishing it from younger glacial lake sediment. Surface exposures of deeply weathered, yellow to orange silt and clay of the Latah Formation can be found below the basalt cap on Fivemile and Orchard Prairies, and Green Bluff and Orchard Bluff (Ml, pl. 1).

\section{Quaternary Geology}

\section{Pleistocene}

During the Pleistocene Epoch, the study area was subjected repeatedly to the erosional and depositional processes associated with glacial and interglacial periods (Kiver and Stradling, 1982, 2001; Kiver and others, 1989). A map of the extent of late-glacial ice and glacial lakes in northern Washington, Idaho, and northwestern Montana is shown in figure 3 . At the maximum extent of the most recent Pleistocene glaciation (about 15,000 years before present), much of northern Washington, Idaho, and westernmost Montana was covered by lobes of the Cordilleran ice sheet (fig. 3). The large ice sheet formed in the mountains of British Columbia and flowed south, filling valleys and overriding low mountain ranges. For thousands of years, lobes of the Cordilleran ice sheet modified the pre-existing landscape through direct ice scour, and through erosion and deposition related to glacial and melt water action. Pre-existing river or melt water drainages were redirected or even blocked, creating ice-age lakes that covered large areas of the inland northwest and resulted in thick accumulations of sediment.
Higher energy environments included glacial outburst flooding and glacial meltwater that deposited vast amounts of sediment along channels and plains. The resulting assemblage of unconsolidated sediment overlies bedrock in much of the study area.

When the Purcell Trench lobe in northern Idaho blocked the drainage of the ancestral Clark Fork in northwestern Montana, Glacial Lake Missoula was created (ig. 3). The lake was about $500 \mathrm{mi}^{3}$ in volume and reached a maximum depth of 2,200 ft (Waitt, 1980). Enormous catastrophic floods occurred over a 2,000-year period when the ice dam of the Purcell Trench lobe periodically failed, sending floodwaters to the west and southwest. The largest of the Missoula floods, many of which probably occurred relatively early in the lake-filling and flooding cycle, overwhelmed local drainages and topped the 2,400-ft divide west of Spokane, spilling south towards Cheney and beyond, and creating the Channeled Scablands (ig. 3 ). When glaciers were at their maximum extent, Missoula outburst floods were mostly routed through the Spokane Valley, then north through the Hillyard trough to the southern portion of the Little Spokane River Basin, and then west through the Long Lake area.

The Pend Oreille River lobe occupied the Pend Oreille River valley and reached its most recent southernmost extent near the northeast extent of the Little Spokane Basin (fig. 3) (Carrara and others, 1995). The terminal area was swept by Lake Missoula floodwaters that followed more northern flood routes (Carrara and others, 1995). After deflecting off of the northern ice lobes, Missoula floodwaters were redirected south through a network of channels south and west of Newport, including Scotia and Camden Gaps (Bjornstad and Kiver, 2012), before eventually emptying into the Deer Park area and the Little Spokane River (pl. 1). Most of the deposits from the catastrophic floods are along the channel of the Little Spokane River, where depositional bars and terraces of sand and gravel hundreds of feet thick were deposited (Boese, 1996).

The Okanogan and Columbia River lobes affected the study area by blocking westward drainage of the ancestral Columbia and Spokane Rivers and creating vast ice-age lakes that resulted in thick accumulations of clay and silt (Waitt and Thorson, 1983). Glacial Lake Columbia, impounded by the Okanogan lobe, was the largest glacial lake in the path of the Missoula floods (fig. 3 ). This lake was long-lived (2,000-3,000 years) and had various surface altitudes depending largely on the degree of blockage by the Okanogan lobe and timing of Lake Missoula outburst floods that brought additional water into the lake. The typical surface altitude of Lake Columbia was about 1,640 ft, but the altitude reached 2,350 ft during maximum blockage by the Okanogan lobe and was as high as about 2,460 ft during the Missoula floods (Atwater, 1986). The higher levels of Glacial Lake Columbia probably occurred early, whereas the lower and more typical level of the lake occurred in later glacial time (Richmond and others, 1965; Waitt and Thorson, 1983; and Atwater, 1986). 


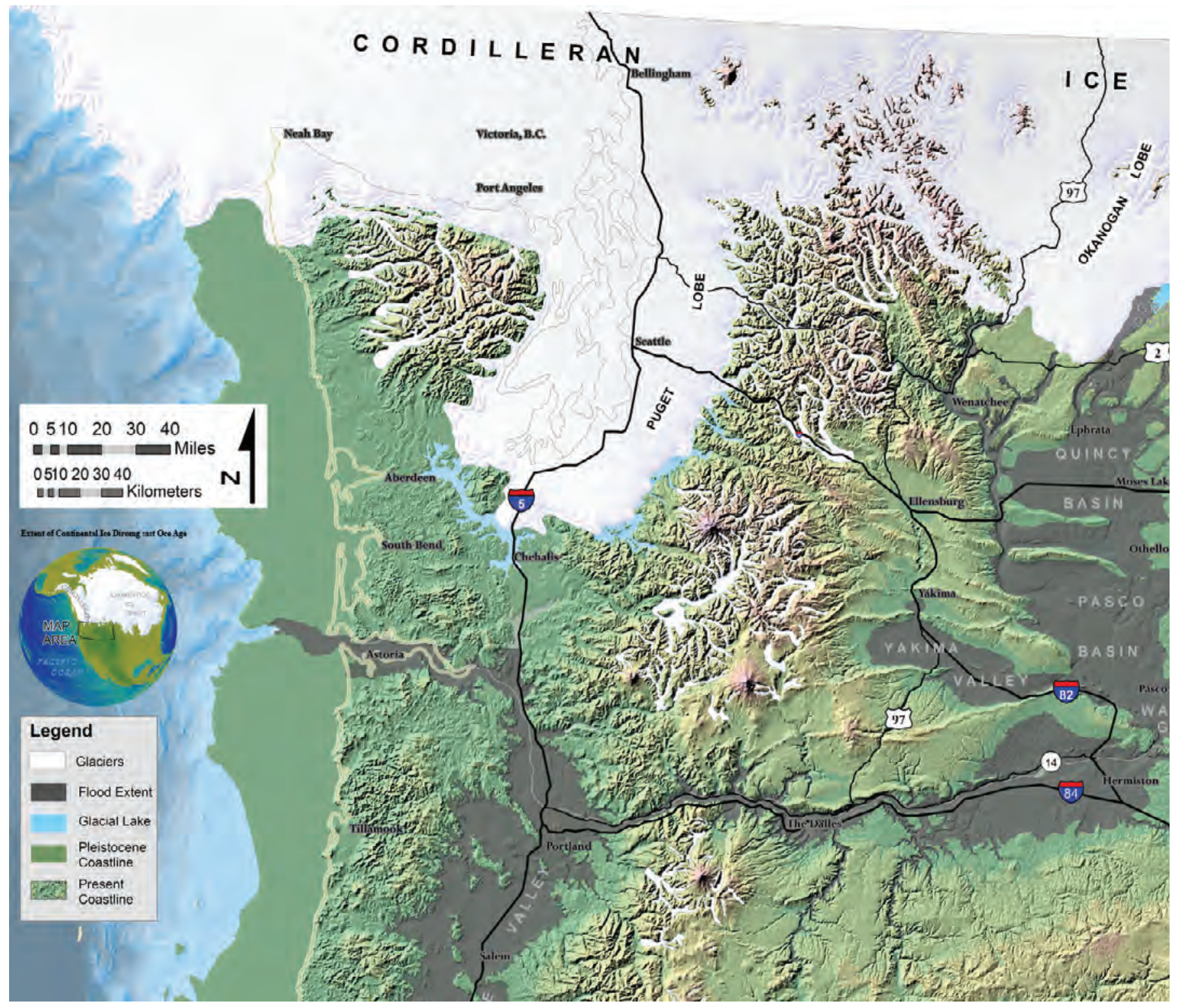

Figure 3. Extent of glacial ice and glacial lakes in northern Washington, Idaho, and parts of Montana. (Modified from U.S. Forest Service, 2010.) 


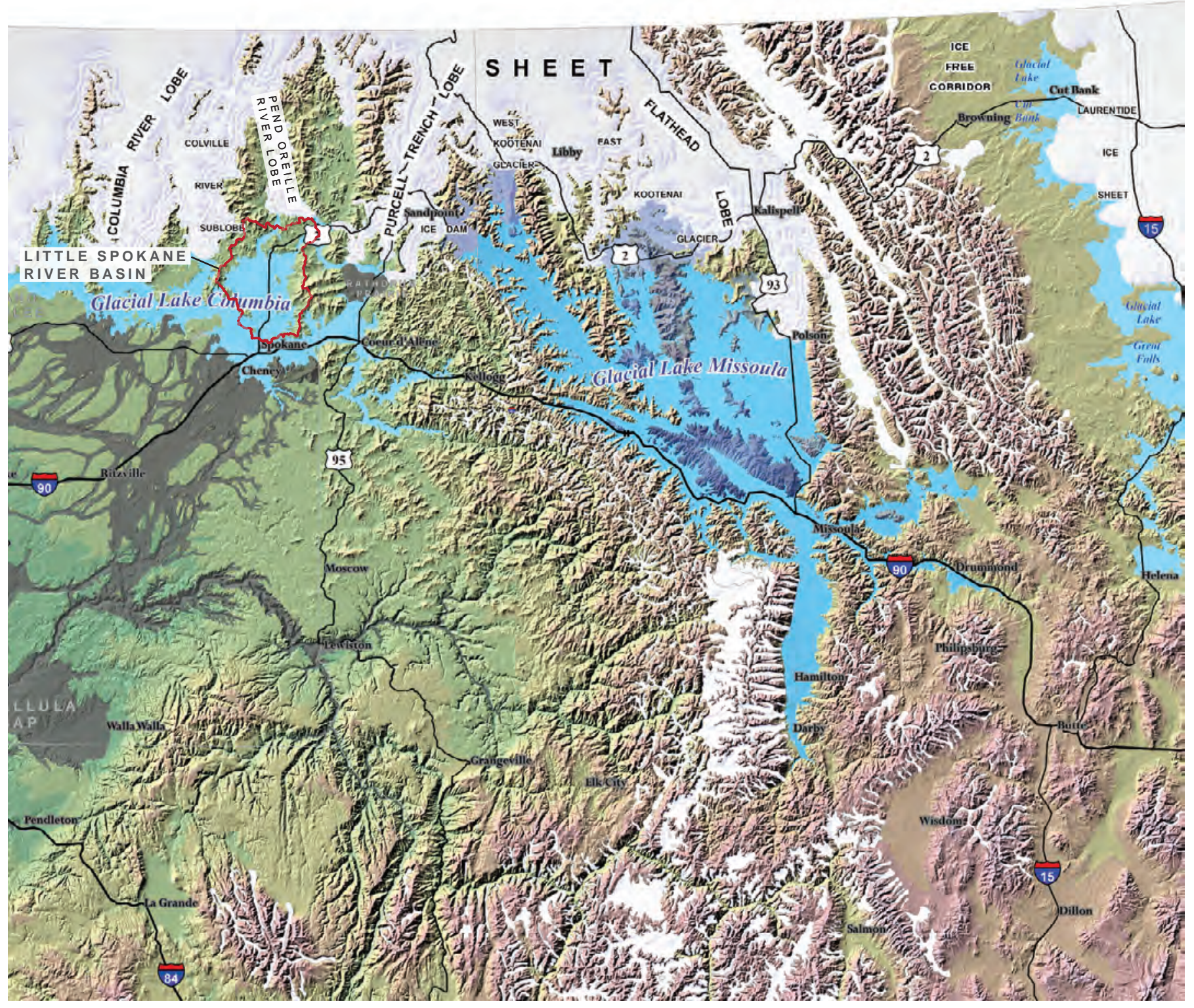

Figure 3.-Continued 


\section{Hydrogeology of the Little Spokane River Basin, Spokane, Stevens, and Pend Oreille Counties, Washington}

Table 1. Geologic timescale with simplified geology of the Little Spokane River Basin study area, Spokane, Stevens, and Pend Oreille Counties, Washington.

[Modified from U.S. Geological Survey Geologic Names Committee (2010). A bbreviations: Mya, million years ago; ya, years ago; -, indicates a gap in the geologic record resulting from erosion and (or) nondeposition]

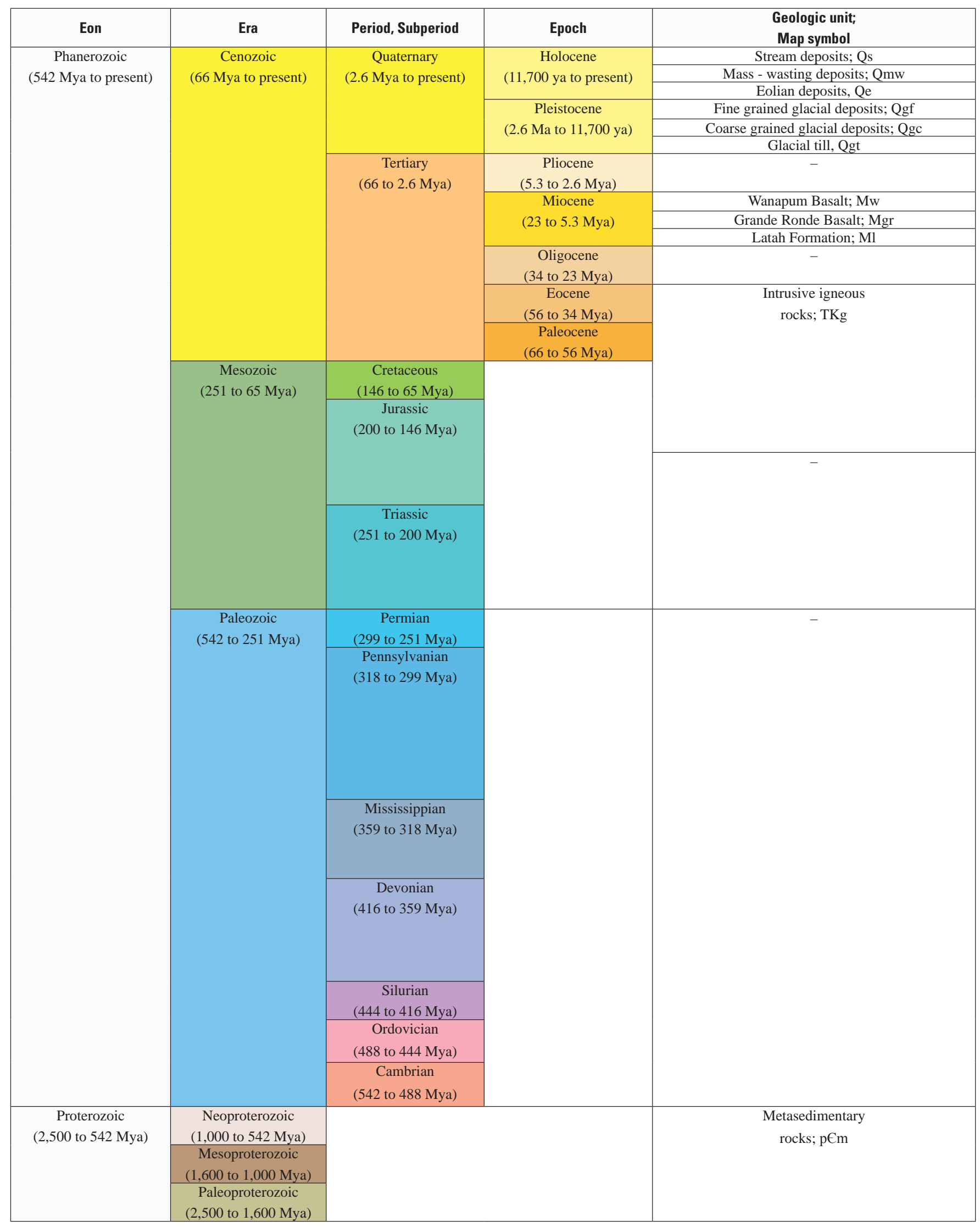


At the higher level of Glacial Lake Columbia (2,350 ft), the glacial lake would have flooded most of the Little Spokane River Basin covering what is now Deer Park and extending to near the top of the basalt bluffs in the southern part of the basin (pl. 1). The long-lived and sediment-rich nature of glacial lakes in the region led to vast thicknesses of mostly fine-grained material being deposited throughout much of the region's lower altitude areas.

Downwind from the ice front, wind-blown sediments were deposited over much of the Columbia Plateau during the Pleistocene (McDonald and Busacca, 1992). This eolian material is informally known as the Palouse loess and consists of angular fragments that are fine sand to silt sized particles of mostly quartz, feldspar, and mica (McDonald and Busacca, 1992). The Little Spokane River Basin is at the northern edge of the Palouse deposition area, so thicknesses generally are less than $25 \mathrm{ft}$ (Boese, 1996). In the southern part of the basin, the unit mantles the basalt bluffs and occurs locally overlying the bedrock.

\section{Holocene}

Following the Pleistocene, rivers and streams have eroded the glacial deposits in many places as well as depositing alluvium along their flood plains. Sand deposited by wind also covers parts of the western side of Peone Prairie and areas around Mead (Boese, 1996).

\section{Geologic Units}

The geology of the study area consists of 11 geologic units (pl. 1).

Recent non-glacial sediment (Qs): This unit includes channel, overbank, and alluvial-fan deposits of rivers and streams, and peat in low-lying and poorly drained areas. Unit consists mostly of stratified silt and sand with some gravel and minor amounts of clay deposited by flowing water.

M ass-wasting deposits (Qmw): Includes poorly sorted angular rock fragments deposited as talus at the base of steep slopes and heterogeneous mixtures of unconsolidated surficial material and rock fragments deposited by landslides. Commonly occurs at the base of the basalt uplands where the unit is composed mostly of Latah Formation and basalt fragments.

E olian deposits (Qe): Unit includes loess—wind-blown silt and fine sand, with minor amounts of clay, blanketing basalt uplands, and dune sand overlying glacial outburst flood deposits in north Spokane and Mead.
Fine-grained glacial deposits (Qgf): Unit includes clay, silt, and sand lake sediments deposited in ice-marginal lakes and sand and silt outwash and distal outburst flood deposits. Unit includes coarse-grained lenses in places.

Coarse-grained glacial deposits (Qgc): Unit includes glacial-outburst flood deposits that consist of sand with gravel, cobbles, and boulders deposited by catastrophic draining of Glacial Lake Missoula and reworked outwash and till deposited by the Pend Oreille lobe. Unit includes localized areas and lenses of fine-grained material.

G lacial till (Qgt): Unit includes mostly poorly sorted and unstratified clay, silt, sand, and gravel deposited by the Pend Oreille River lobe. In the study area, the unit occurs only near Newport, where the unit includes the terminal moraine of the Pend Oreille River lobe.

Wanapum Basalt (Mw): Unit includes the Wanapum Basalt, Priest Rapids Member, of the Columbia River Basalt Group. Unit is composed of fine- to coarse-grained basalt flows with olivine and plagioclase phenocrysts. The unit overlies the Grande Ronde Basalt and, when present, the Latah Formation. The Priest Rapids Member is also invasive into Latah Formation. Forms prominent rim rock and steep cliffs (Greenbluff and Fivemile Prairie), commonly with well-developed columnar jointing.

G rande R onde Basalt (Mgr): Unit includes the Grande Ronde Basalt of the Columbia River Basalt Group. Unit is composed of black to dark gray, fine-grained, dense to slightly vesicular flows composed of dark-brown glass, plagioclase, pyroxene, and minor olivine. Flows are commonly pillowed, indicating the basalt flowed into water. Overlies or is invasive into the Latah Formation; where Latah Formation is absent, the Grande Ronde overlies older crystalline rocks.

L atah Formation (Ml): Unit includes lacustrine and fluvial deposits of gray to tan to yellow orange siltstone, claystone, and minor sandstone that underlie and are interbedded with the Grande Ronde Basalt and Priest Rapids Member of the Wanapum Basalt in the Spokane area. The unit locally contains fossil leaves and carbonized logs.

Intrusive igneous rocks (TKg): Unit is generally described as granite and includes fine- to coarse-grained, equigranular to porphyritic, muscovite-biotite granite, hornblende-biotite granite, granodiorite, and quartz monzonite.

M etamorphic rocks ( $\mathrm{p} € \mathrm{~m}$ ): Unit includes strongly foliated and layered, fine- to coarse-grained gneiss, schist, and quartzite; minor amphibolite and hornfels; meta-argillite and metasiltite, and metadolomite. 


\section{Hydrogeologic Units}

The geologic units and the deposits at depth were differentiated into aquifers and confining beds on the basis of areal extent and general water-bearing characteristics. An aquifer is saturated geologic material that is sufficiently permeable to yield water in significant quantities to a well or spring, whereas a confining bed has lower permeability that restricts the movement of groundwater and limits the usefulness of the unit as a source of groundwater. Generally, well-sorted, coarse-grained deposits have greater permeabilities than do fine-grained or poorly sorted deposits. In the Little Spokane River Basin, saturated glacial outwash or other coarse-grained deposits form the primary aquifers, whereas deposits such as lacustrine or glaciolacustrine deposits form the confining beds. The aquifers and confining beds identified herein are referred to as hydrogeologic units because the differentiation takes into account both the geologic and hydraulic characteristics of the units. Eight hydrogeologic units were identified in the study area, based on their areal extent and general water-yielding properties:

- Upper aquifer (UA);

- Upper confining unit (UC);

- Lower aquifers (LA);

- Lower confining unit (LC);

- Wanapum basalt unit (B1);

- Latah unit (LT);

- Grande Ronde basalt unit (B2); and

- Bedrock (BR).

A simplified conceptual model of the hydrologic system of the Little Spokane River Basin (fig. 4) illustrates a series of unconsolidated sedimentary deposits and basalt layers (together referred to as basin fill) overlying the "basin" of crystalline bedrock. Figure 4 is representative of approximately the southern half of the Little Spokane River Basin where basin-fill deposits are composed mostly of low permeability fine-grained material overlain or interbedded with coarse-grained material (sand and gravel) or basalt, in places. Farther north in the basin, the basin-fill deposits are generally thinner and the basalt does not extend beyond the Eloika Lake area (fig. 1).

The lithologic and hydrologic characteristics of the hydrogeologic units are summarized in a table that includes the range of thicknesses for each unit, based on data from the inventoried wells, and the number of inventoried wells open to each unit (table 2). Wells open to more than one unit are not included in the chart, but are indicated in table 4. Project well locations are shown on plate 2 and are color coded based on the hydrogeologic unit that the wells are open to; wells completed in multiple units, exploratory bore holes, and wells without available drillers' logs are designated as Other and are shown as gray dots; wells open to the Spokane Valley-Rathrum Prairie aquifer are shown as black dots. The thickness and areal extent of the units are shown on nine hydrogeologic sections and exhibit considerable variation (pl. 2). Adequate data were available to map the approximate thickness and extent of the Upper aquifer, the Lower aquifers, and the Grande Ronde basalt unit. The hydrogeologic units are commonly heterogeneous and locally discontinuous; therefore, correlations are tentative in many places. The Upper confining unit, Lower confining unit, and the Latah unit are virtually indistinguishable in drillers' descriptions of material detected during well construction. Generally, the first or upper confining material detected during drilling was considered part of the Upper confining unit. If a deeper confining unit was detected below a lower aquifer, it was considered part of the Lower confining unit. Confining beds (with or without associated sandy zones) either below or associated with basalt were considered part of the Latah unit. Along much of the Little Spokane River valley floor, the depth to bedrock, and therefore the total thickness of the unconsolidated deposits, is not well known. Generally, the deeper the units, the less certain are the correlations.

A summary of well yields, as reported on drillers' logs used during this investigation, is also shown on table 2 by hydrogeologic unit. Well-yield testing is done to determine if an adequate and sustainable yield is available from a well. Driller-reported well yields are not only dependent on the productivity of the unit to which the well is open, but also is a function of the design and purpose of the well. During well-yield testing, a municipal well likely would be pumped at a higher rate and have a larger diameter casing and a longer open interval than one intended for single-family use, thereby having an apparent greater yield than that for the single-family well. Despite the fact that yields often are estimates, they are useful in comparing the general productivity of hydrogeologic units; they also illustrate the variability within a single unit. Based on the available driller-reported yields from 353 of the project wells, yields ranged overall from 0 to $5,000 \mathrm{gal} / \mathrm{min}$, with a median yield of $15 \mathrm{gal} / \mathrm{min}$.

A summary of specific capacity information, derived from driller-reported yield divided by the drawdown measured in the well during pumping, is also provided, by hydrogeologic unit (table 2). Specific capacity often is used to describe the productivity of a hydrogeologic unit and is expected to be smaller for confined aquifers than unconfined aquifers (Freeze and Cherry, 1979). Based on the available driller-reported yields and drawdowns of 20 of the project wells, the median specific capacity overall, ranged from 0.7 to 300 (gal $/ \mathrm{min}) / \mathrm{ft}$, with a median of $84(\mathrm{gal} / \mathrm{min}) / \mathrm{ft}$. 


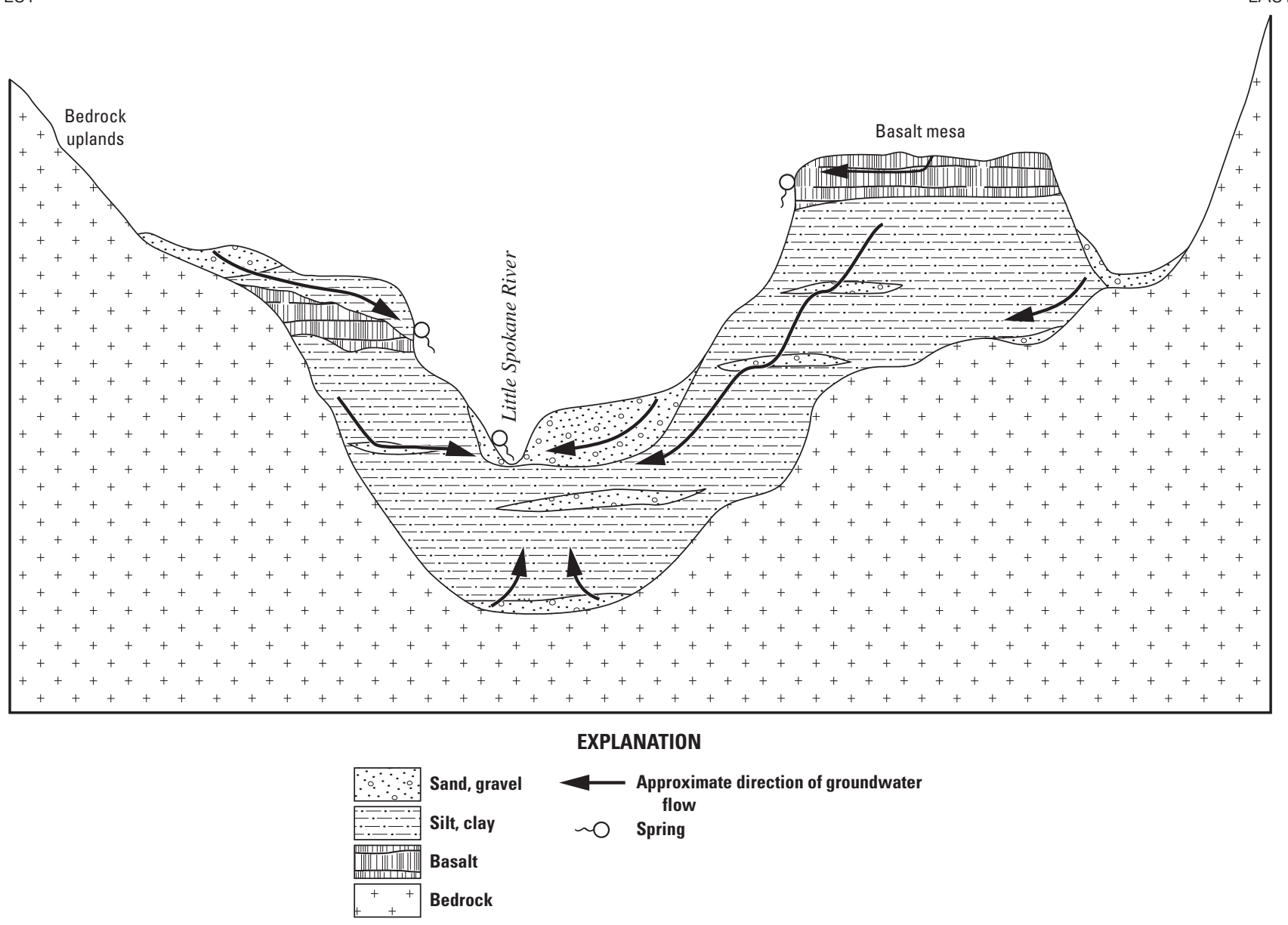

Figure 4. Conceptual model of the hydrogeologic system in the Little Spokane River Basin, Spokane, Stevens, and Pend Oreille Counties, Washington. 


\begin{tabular}{|c|c|c|c|c|c|c|c|c|c|}
\hline 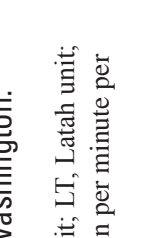 & 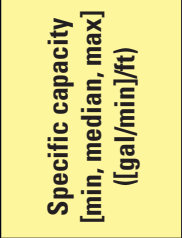 & $\bar{d}$ & $\bar{J} \Xi$ & 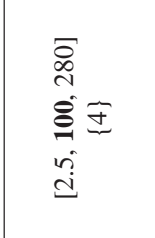 & 1 & 1 & 1 & న。 & I \\
\hline 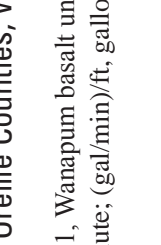 & 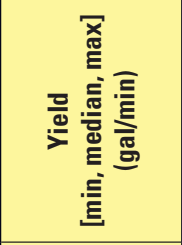 & 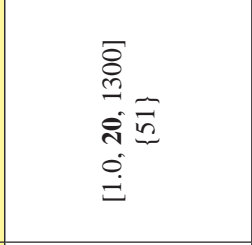 & 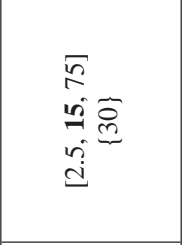 & 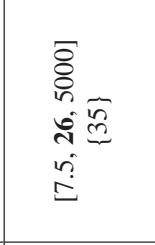 & $\bar{\Xi} \Xi$ & $\Xi \Xi$ & 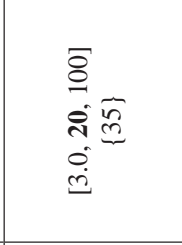 & 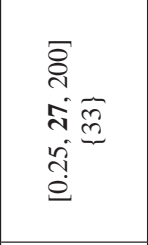 & 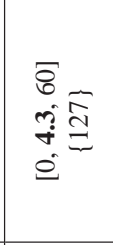 \\
\hline 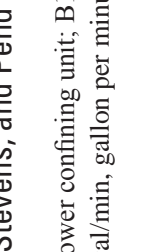 & 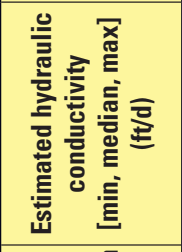 & 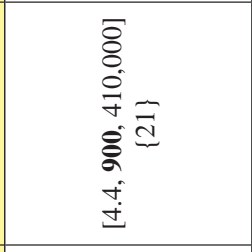 & 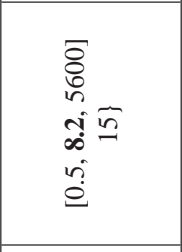 & 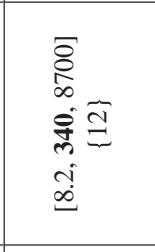 & $\widetilde{\mathbb{J}} \approx$ & $\underset{J}{\mathbb{J}} \Xi$ & $\begin{array}{l}\sqrt{n} \\
0 \\
0 \\
0 \\
0 \\
0 \\
0 \\
0 \\
0\end{array}$ & 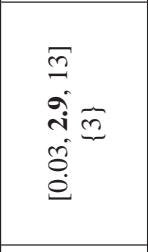 & 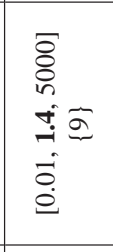 \\
\hline 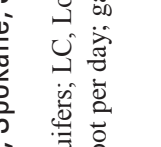 & 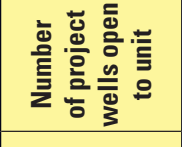 & in & $\mathscr{m}$ & $\mathscr{m}$ & $\neg$ & N & ले & 늘 & $\underset{\exists}{ت}$ \\
\hline 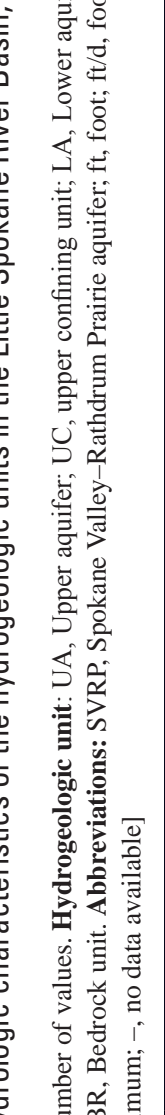 & 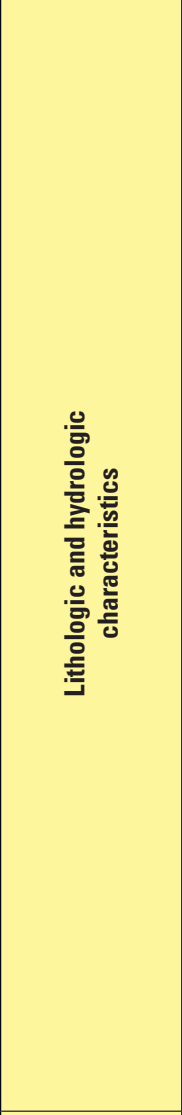 & 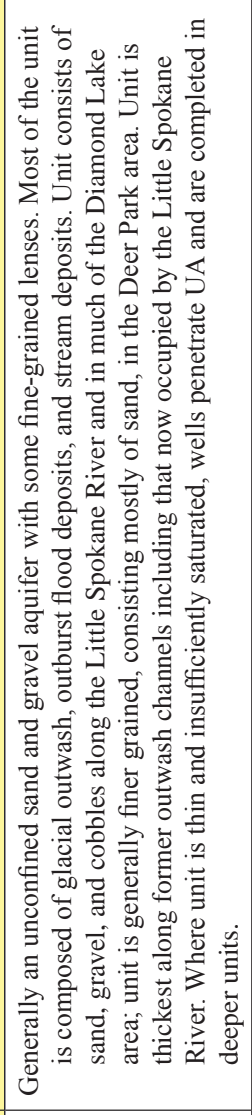 & 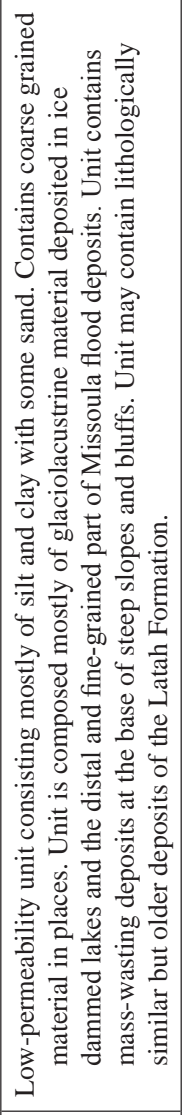 & 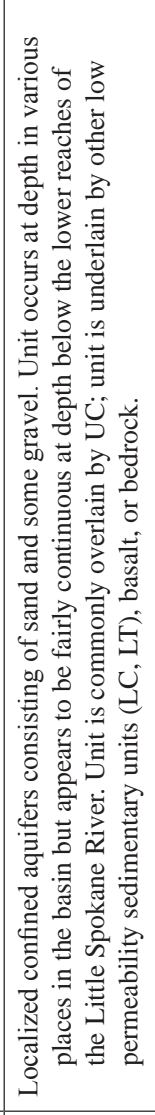 & 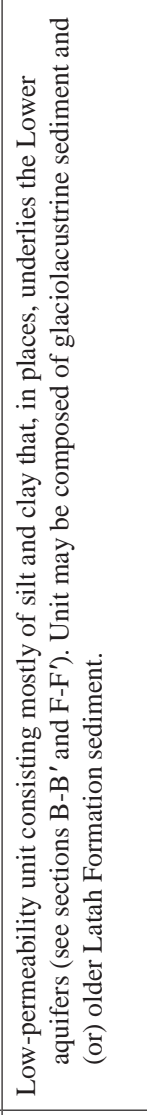 & 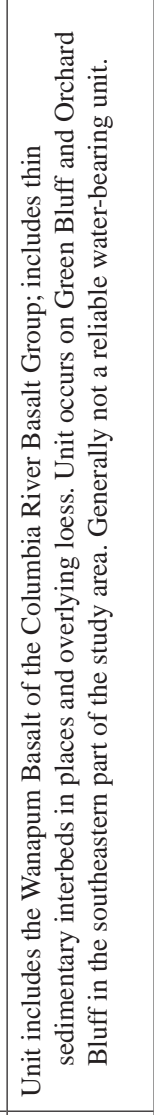 & 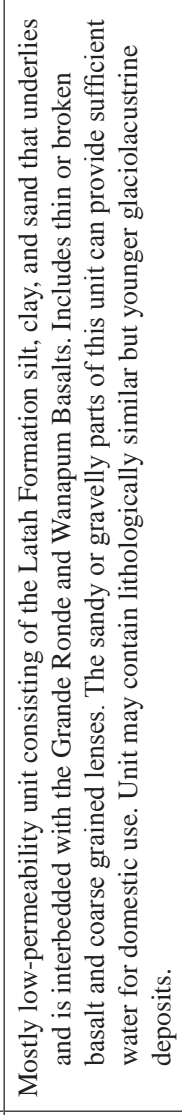 & 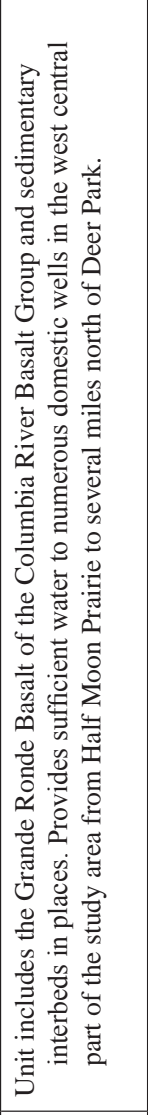 & 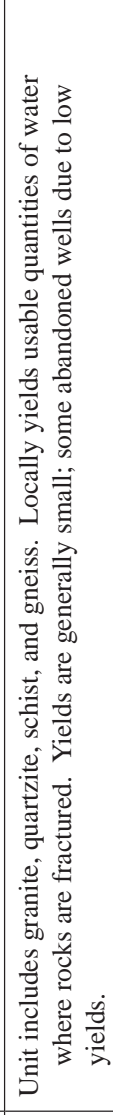 \\
\hline 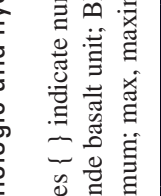 & 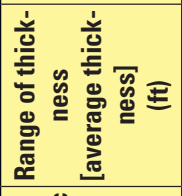 & 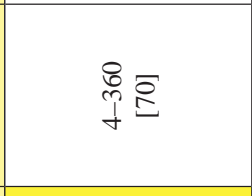 & 守宫 & 员 & 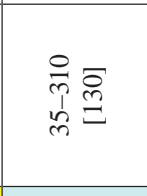 & $\underset{9}{g}$ & 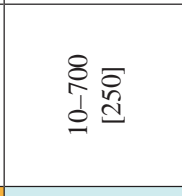 & 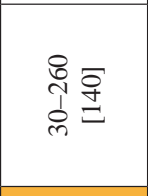 & ž \\
\hline 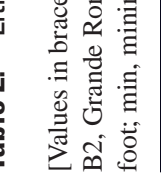 & 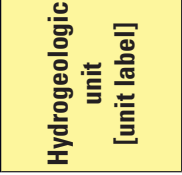 & 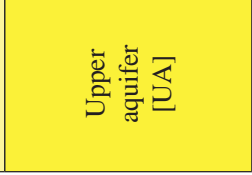 & 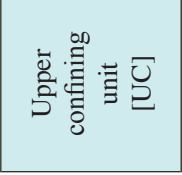 & 氙氙宓 & 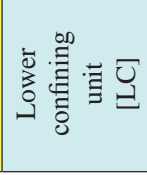 & 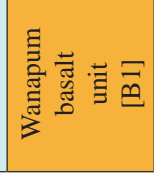 & $\Xi$ & 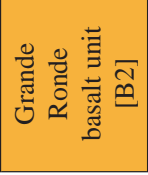 & 递自蛋 \\
\hline
\end{tabular}




\section{Bedrock Unit}

The Bedrock unit underlies the entire basin and occurs at land surface on about 44 percent of the basin's surface area, including most of the higher altitudes areas (pl. 2). Rock types included in this unit are granite, quartzite, schist, and gneiss; these rocks yield usable quantities of water where rocks are fractured. Although this unit generally yields only small quantities of water, it is the only available source of water where overlying saturated sediments are absent. Roughly one-third of the project wells (141 wells) are completed in the Bedrock unit (pl. 2). The depths of the project wells completed in the Bedrock unit range from 52 to $800 \mathrm{ft}$, with a median depth of $320 \mathrm{ft}$. The estimated horizontal hydraulic conductivity ranges from 0.01 to 5,000 ft/d, with a median hydraulic conductivity of $1.4 \mathrm{ft} / \mathrm{d}$ (table 2). The driller-reported yields for Bedrock unit wells ranged from 0 (those noted as 'dry') to $60 \mathrm{gal} / \mathrm{min}$, with a median yield of $4.3 \mathrm{gal} / \mathrm{min}$ (table 2). Several of the project wells completed in the Bedrock unit are unused due to insufficient yields.

The approximate altitude of the top of the bedrock, or pre-Tertiary basement, is shown in figure 5. This contour map is based on information from the geologic map, well logs for project wells, the hydrogeologic sections, and a bedrock elevation map developed by Boese (1996) for the southern part of the basin. Contours for the buried bedrock surface were manually drawn in 200-ft intervals and lie within the extent of the Little Spokane River Basin. Along the bedrock's outcrop area, subsurface contours were tied to DEM-derived land-surface contours, also in 200-ft intervals. The altitude of the bedrock is about 2,200 ft near Diamond Lake, about 1,200 ft beneath Peone Prairie, and about 1,600 ft near the Little Spokane River at Dartford (USGS Station No. 12431000; fig. 1).

\section{Basin Fill}

The long and varied geologic history of the Little Spokane River Basin has led to varying thickness of basin fill overlying bedrock. To estimate and illustrate the thickness of basin fill, which includes all of the hydrogeologic units described in this report-except the Bedrock unit-a 10-m Digital Elevation Model of land surface was used along with the altitude of bedrock to subtract the first from the latter in order to get approximate thickness of basin fill. Basin fill is greatest in Peone Prairie, Half Moon Prairie, Orchard Bluff, and Green Bluff (igss. 1 and $\underline{6}$ ).

\section{Upper Aquifer}

The Upper aquifer is composed mostly of sand and gravel, with some fine-grained lenses, and includes material deposited by glacial meltwater, glacial outburst floods, and streams. The Upper aquifer consists of sand, gravel, and cobbles along the Little Spokane River and in much of the Diamond Lake area. The aquifer is generally finer grained, consisting mostly of sand, in the Deer Park area, and in areas farther from main outwash channels. Where the unit is thin and insufficiently saturated, wells penetrate the Upper aquifer and are completed in deeper units (hydrogeologic sections, pl. 2).

The Upper aquifer occurs on about 32 percent of the surface area of the basin (pl. 2) and varies in thickness from 4 to $360 \mathrm{ft}$, with an average thickness of $70 \mathrm{ft}$ (table 2). The unit is thickest along former outwash channels, including the channel now occupied by the Little Spokane River, and in the Diamond Lake area (fig. 7).

Fifty-seven of the project wells are completed in the unit; the locations of which are shown on plate 2. The depths of the project wells completed in this aquifer range from 29 to $243 \mathrm{ft}$, with a median depth of $88 \mathrm{ft}$. The estimated horizontal hydraulic conductivity ranges from 4.4 to $410,000 \mathrm{ft} / \mathrm{d}$, with a median hydraulic conductivity of $900 \mathrm{ft} / \mathrm{d}$ (table 2). Landau (1991) and Boese (1996) reported hydraulic conductivity values of about 500-600 ft/d for the Upper aquifer. Median values of hydraulic conductivity for similar aquifers in neighboring Colville and Chamokane valleys were 84 and $540 \mathrm{ft} / \mathrm{d}$, respectively (Kahle and others, 2003 and 2010). The driller-reported yields for the Upper aquifer wells ranged from 1.0 to 1,300 gal/min, with a median yield of $20 \mathrm{gal} / \mathrm{min}$ (table 2). Data were available for only one specific capacity estimate-300 (gal/min)/ft (table 2). For the most part, the aquifer is under unconfined or water table conditions, except where less permeable material may cause confined conditions locally.

\section{Upper Confining Unit}

The Upper confining unit is a low-permeability unit consisting mostly of silt and clay with some sand; coarse-grained lenses occur locally (pl. 2, sections $A-A^{\prime}$ and $\left.E-E^{\prime}\right)$. The unit is composed mostly of glaciolacustrine material deposited in ice-dammed lakes and the distal and fine-grained part of Missoula flood deposits. In places, the unit contains mass-wasting deposits at the base of steep slopes, and lithologically similar but older deposits of the Latah Formation. The Upper confining unit occurs on about 20 percent of the surface area of the basin (pl. 2) and varies in thickness from 5 to $400 \mathrm{ft}$, with an average thickness of $100 \mathrm{ft}$ (table 2). The lateral extent of the unit is difficult to determine due to similar lithologic properties with the Latah unit and Lower confining unit (pl. 2, sections $B-B^{\prime}$ and $C-C^{\prime}$ ). 


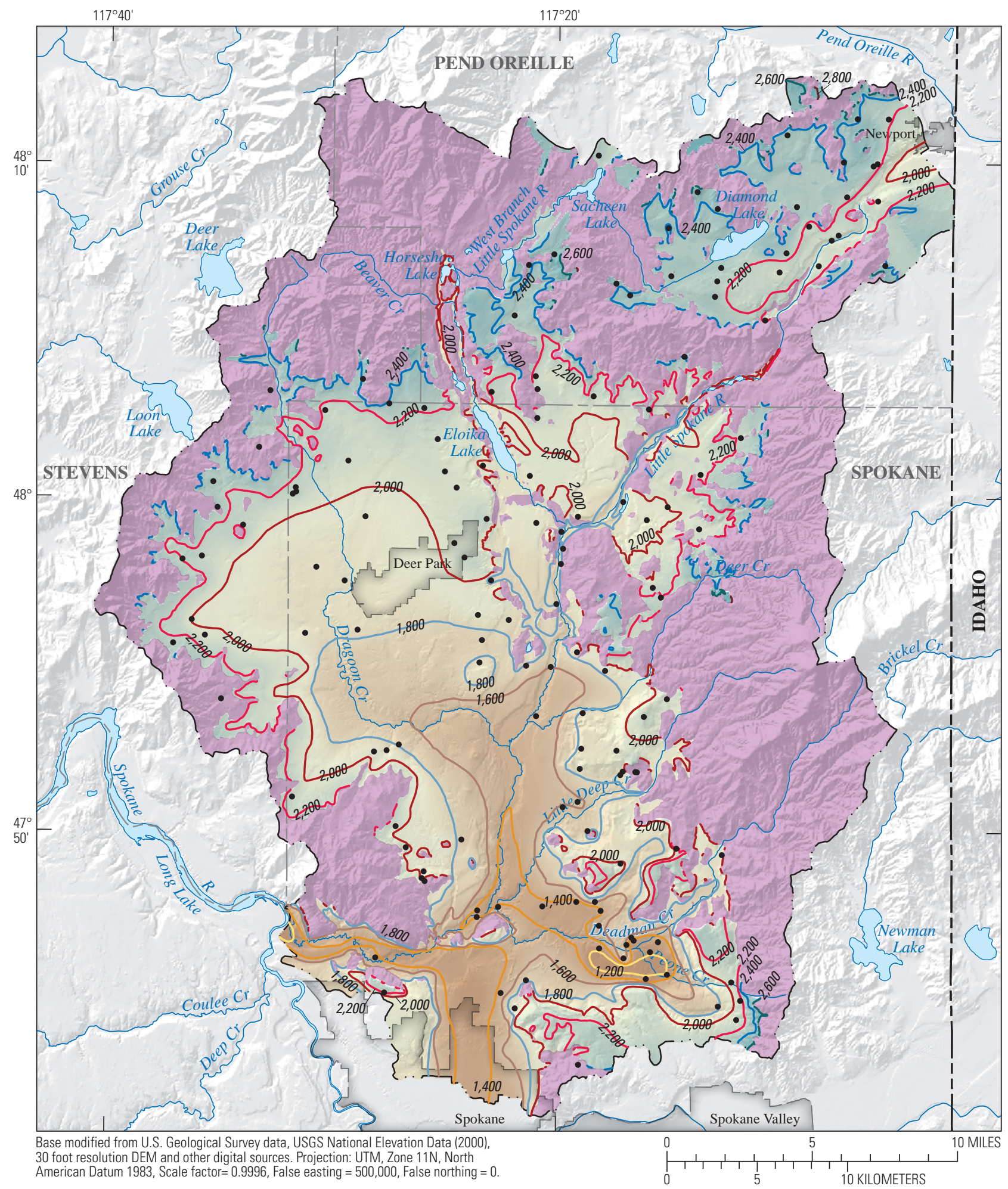

\section{EXPLANATION}
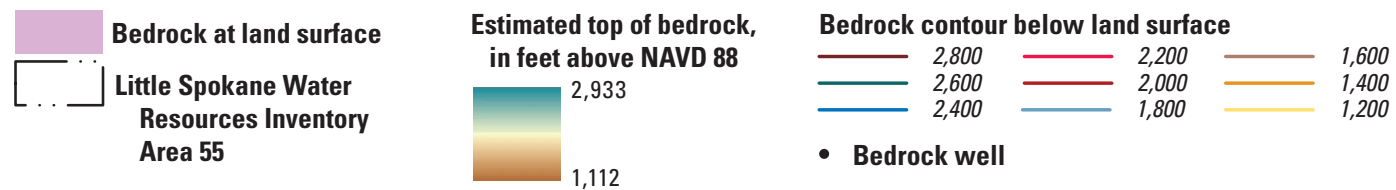

Figure 5. Estimated altitude of the top of the bedrock in the Little Spokane River Basin, Spokane, Stevens, and Pend Oreille Counties, Washington. 


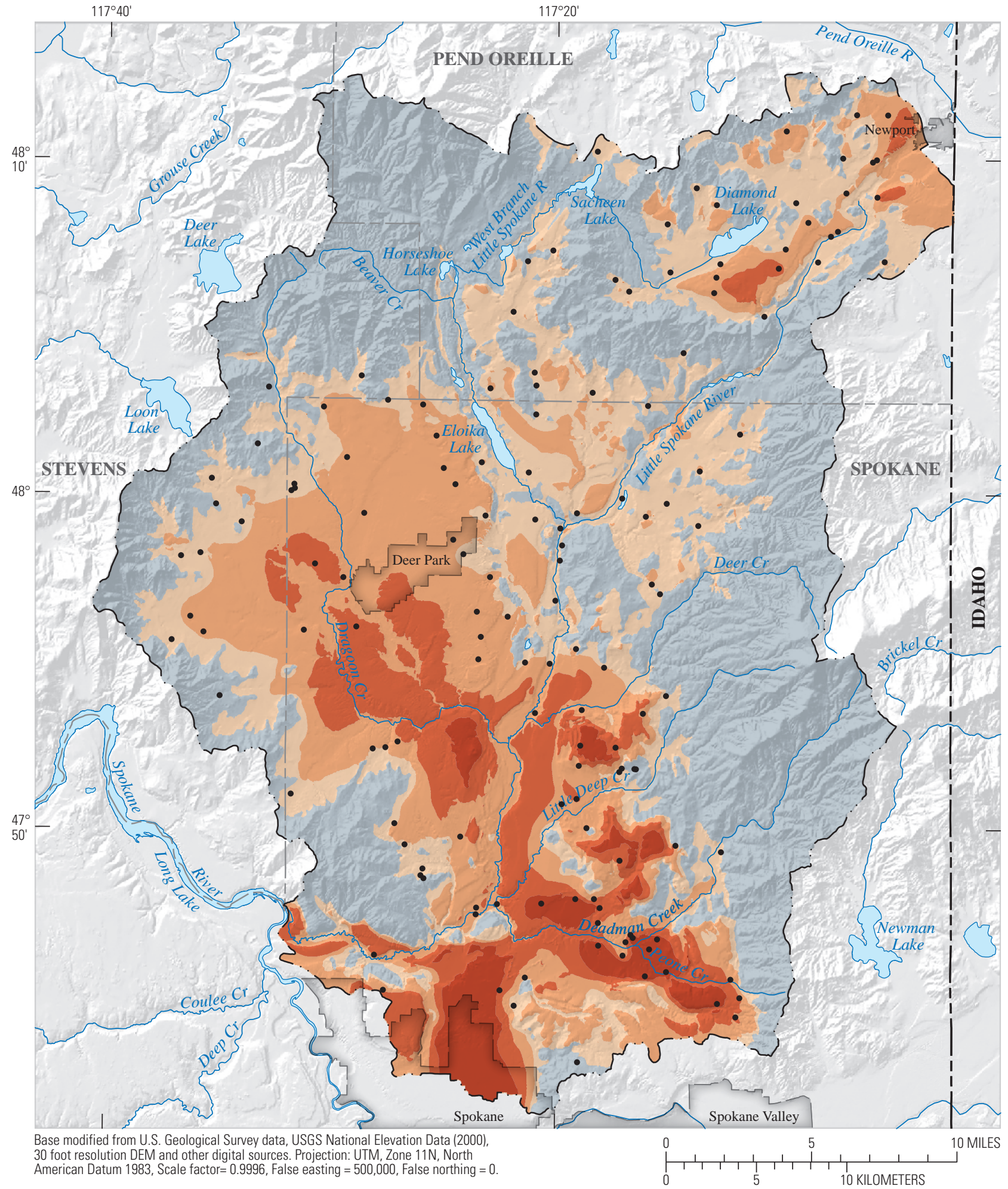

EXPLANATION

\section{Bedrock at land surface \\ [.. Little Spokane Water Resources Inventory Area 55}

- Bedrock well
Extent and thickness of basin fill, in feet

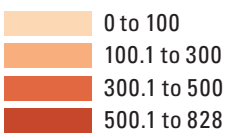

Figure 6. Thickness of basin fill over bedrock in the Little Spokane River Basin, Spokane, Stevens, and Pend Oreille Counties, Washington. 


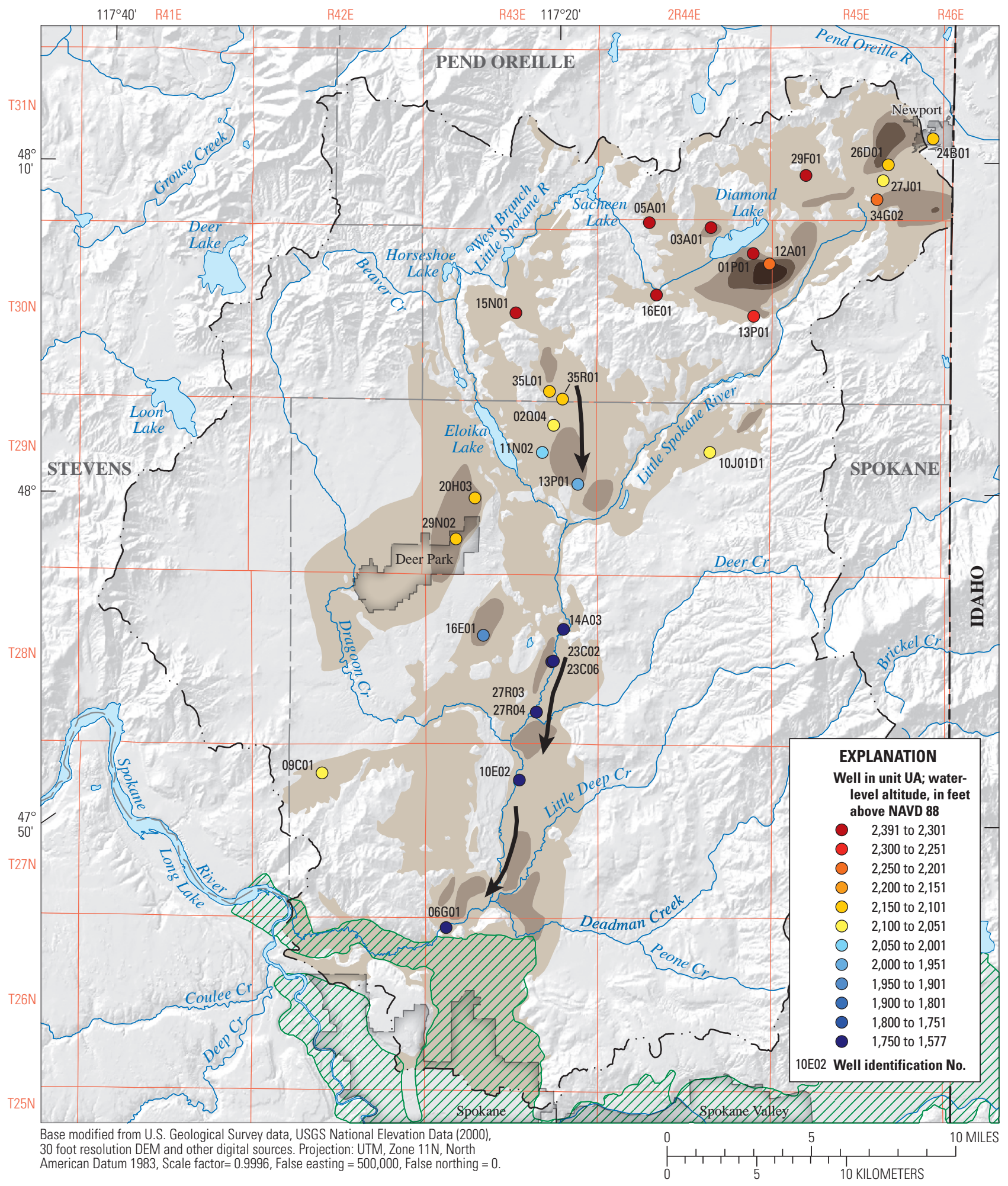

\section{EXPLANATION}

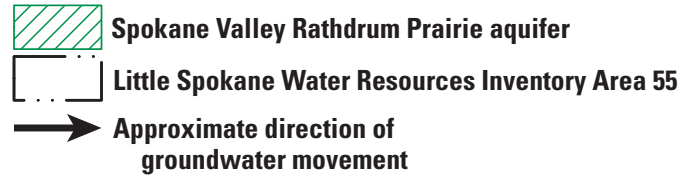

Extent and thickness of UA, in feet

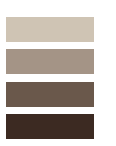

Less than 100

101 to 200

201 to 300

Greater than 300

Figure 7. Thickness and areal extent, and water-level altitudes and inferred directions of groundwater flow of the Upper aquifer (UA) in the Little Spokane River Basin, Spokane, Stevens, and Pend Oreille Counties, Washington. 
Thirty-six of the project wells are completed in the Upper confining unit (pl. 2). The depths of the project wells completed in this unit range from 18 to $470 \mathrm{ft}$, with a median depth of $95 \mathrm{ft}$. The estimated horizontal hydraulic conductivity ranges from 0.5 to $5,600 \mathrm{ft} / \mathrm{d}$, with a median hydraulic conductivity of $8.2 \mathrm{ft} / \mathrm{d}$ (table 2). The median value of hydraulic conductivity for a confining unit of the same origin (glacial lake sediment) in neighboring Chamokane valley was $10 \mathrm{ft} / \mathrm{d}$, (Kahle and others, 2010). The driller reported yields for the Upper confining unit ranged from 2.5 to $75 \mathrm{gal} / \mathrm{min}$, with a median yield of $15 \mathrm{gal} / \mathrm{min}$ (table 2). Data are available for only one specific capacity estimate2.4 (gal/min)/ft (table 2).

\section{Lower Aquifers}

This unit consists of localized confined aquifers consisting of sand and some gravel that occurs at depth in various places in the basin but appears to be fairly continuous at depth below the lower reaches of the Little Spokane River (section $F-F^{\prime}$, pl. 2; fig. 8). The unit is overlain by the Upper confining unit and underlain by other low-permeability sedimentary units (Lower confining unit, Latah unit), basalt, or bedrock.

Thirty-six of the project wells are completed in the Lower aquifers (pl. 2). The depths of the project wells completed in this unit range from 102 to $435 \mathrm{ft}$, with a median depth of $178 \mathrm{ft}$. Based on data from the project wells, the thickness of the unit ranges from 8 to $150 \mathrm{ft}$, with an average thickness of $50 \mathrm{ft}$. The estimated horizontal hydraulic conductivity ranges from 8.2 to $8,700 \mathrm{ft} / \mathrm{d}$, with a median hydraulic conductivity of $340 \mathrm{ft} / \mathrm{d}$ (table 2). Landau (1991) and Boese (1996) reported hydraulic conductivity values of about 100-200 ft/d for the Lower aquifers. Median values of hydraulic conductivity for similar aquifers in neighboring Colville and Chamokane valleys were 50 and $20 \mathrm{ft} / \mathrm{d}$, respectively (Kahle and others, 2003 and 2010). The driller-reported yields for wells in the Lower aquifers ranged from 7.5 to $5,000 \mathrm{gal} / \mathrm{min}$, with a median yield of $26 \mathrm{gal} / \mathrm{min}$ (table 2). Specific capacity estimates ranged from 2.5 to 280 (gal/min)/ft, with a median of 100 (gal/min)/ft (table 2).

\section{Lower Confining Unit}

The Lower confining unit is a low-permeability unit consisting mostly of silt and clay that, in places, underlies the Lower aquifers (pl. 2, see sections $B-B^{\prime}$ and $F-F^{\prime}$ ). The unit may be composed of glaciolacustrine sediment and (or) older Latah Formation sediment. The thickness of the unit ranges from 35 to $310 \mathrm{ft}$, with an average thickness of $130 \mathrm{ft}$. Although several wells penetrate the Lower confining unit, only one of the project wells, 27N/43E-35E02, is open to it; the location of which is shown on plate 2 (section $F-F^{\prime}$ ). The depth of well 27N/43E-35E02 is $570 \mathrm{ft}$; the estimated hydraulic conductivity is $0.2 \mathrm{ft} / \mathrm{d}$, and the driller-reported yield is $6 \mathrm{gal} / \mathrm{min}$.

\section{Wanapum Basalt Unit}

The Wanapum basalt unit includes the Wanapum Basalt of the Columbia River Basalt Group, thin sedimentary interbeds, and in places, overlying loess. The unit occurs as isolated remnants on Green Bluff, Orchard Bluff, Peone Prairie, and Fivemile Prairie. Ader (1996) reported that the Green Bluff basalt aquifer is spatially isolated from sources of regional groundwater recharge and that water-level declines (as of 1992) in the aquifer were due to losses (pumping from wells and spring discharge) exceeding recharge to the aquifer.

Based on data from project wells, the unit ranges in thickness from 7 to $140 \mathrm{ft}$, with an average thickness of $60 \mathrm{ft}$. Only two of the project wells, 26N/43E-23C03 and 28N/44E-07L01 are completed in the Wanapum basalt unit (pl. 2). The depths of the wells are 144 and $73 \mathrm{ft}$, respectively. Well 26N/43E-23C03 has an estimated hydraulic conductivity of $2.4 \mathrm{ft} / \mathrm{d}$ and driller-reported yield of $19 \mathrm{gal} / \mathrm{min}$. For comparison, the median horizontal hydraulic conductivity for the Columbia River basalts (Saddle Mountains, Wanapum, and Grande Ronde units combined) was $70 \mathrm{ft} / \mathrm{d}$ based on data from 573 wells (Kahle and others, 2011).

\section{Latah Unit}

The Latah unit is a mostly low-permeability unit consisting of the Latah Formation silt, clay, and sand that underlies and is interbedded with the Grande Ronde and Wanapum Basalts. The unit includes thin or broken basalt and coarse-grained lenses in places. The unit may also contain lithologically similar but younger glaciolacustrine deposits. The sandy zones of this unit can provide sufficient water for domestic use. Based on data from project wells, the unit ranges in thickness from 10 to $700 \mathrm{ft}$, with an average thickness of $250 \mathrm{ft}$; it is important to note, however, that generally only the coarser zones of this unit provide sufficient water for modest use.

Numerous project wells were open to the Latah unit as illustrated on sections $A-A^{\prime}$ through $E-E^{\prime}$ (pl. 2). The Latah unit is commonly hundreds of feet thick in the southern part of the basin beneath the basalt bluffs and Peone Prairie. On Green Bluff, in well 27N/44E-20K02, $595 \mathrm{ft}$ of clay and silt was drilled through (pl. 2, section $A-A^{\prime}$ ); on Orchard Bluff, in well 28N/43E-36P02, $511 \mathrm{ft}$ of clay was drilled through (pl. 2, section $\left.C-C^{\prime}\right)$. The Latah unit thins to the north and is about $100 \mathrm{ft}$ thick near Deer Park (pl. 2, section $E-E^{\prime}$ ).

Thirty-four of the project wells are completed in the Latah unit (pl. 2). The depths of the project wells completed in this unit range from 79 to $660 \mathrm{ft}$, with a median depth of $292 \mathrm{ft}$. The estimated horizontal hydraulic conductivity ranges from 0.19 to $15 \mathrm{ft} / \mathrm{d}$, with a median hydraulic conductivity of $0.56 \mathrm{ft} / \mathrm{d}$ (table 2). The driller reported yields for the Latah unit wells ranged from 3.0 to $100 \mathrm{gal} / \mathrm{min}$, with a median yield of $20 \mathrm{gal} / \mathrm{min}$ (table 2). 


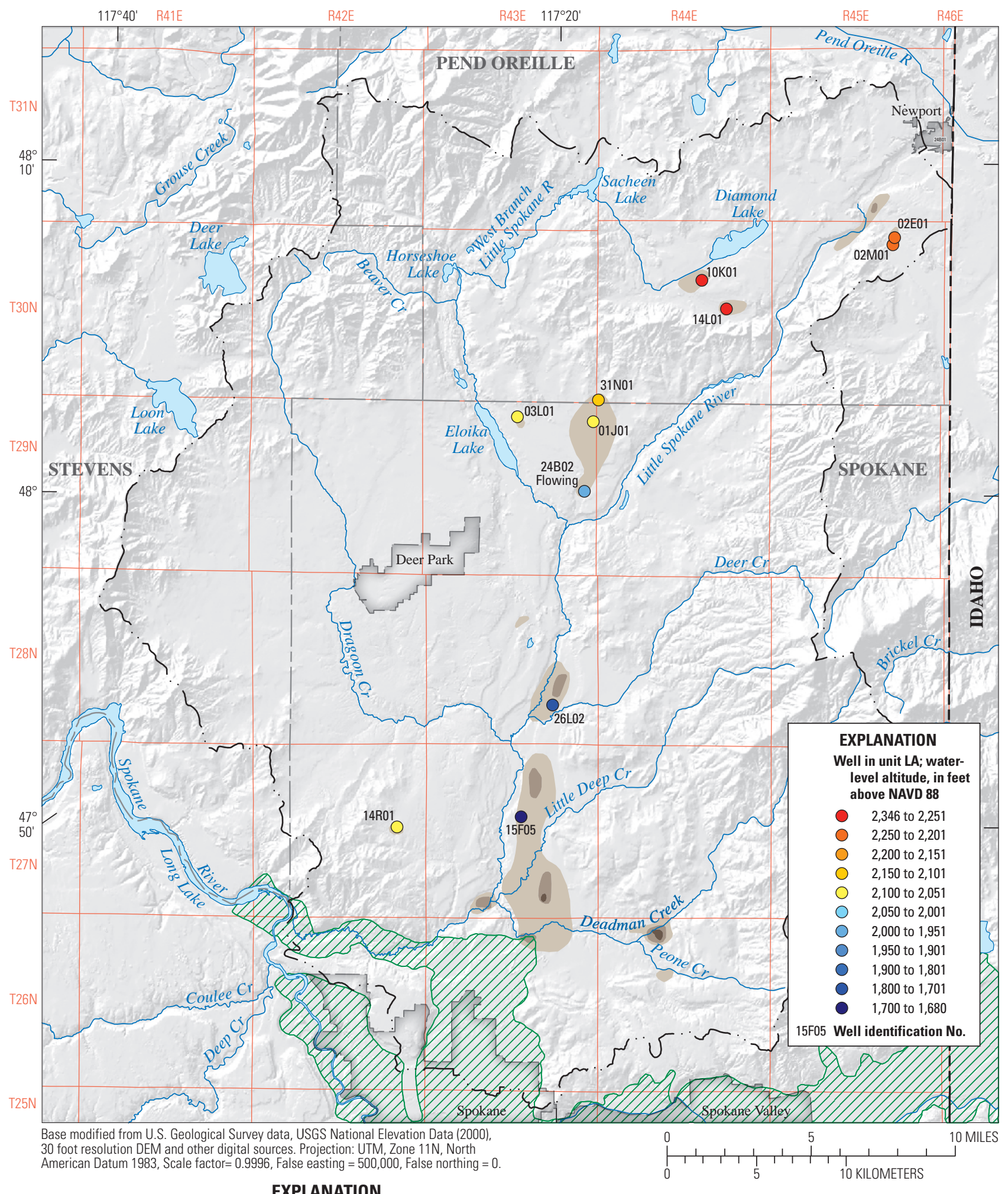

EXPLANATION

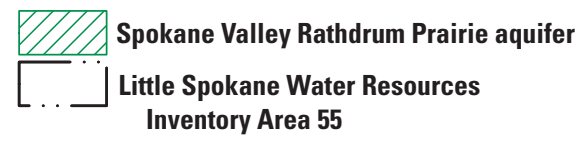

Extent and thickness of

$L A$, in feet

Less than 50

51 to 100

Greater than 100

Figure 8. Thickness and areal extent, and water-level altitudes of the Lower aquifers (LA) in the Little Spokane River Basin, Spokane, Stevens, and Pend Oreille Counties, Washington. 


\section{Grande Ronde Basalt Unit}

The Grande Ronde unit includes the Grande Ronde Basalt of the Columbia River Basalt Group and sedimentary interbeds, in places. This unit provides sufficient water to numerous domestic wells in the west-central part of the study area from Half Moon Prairie to several miles north of Deer Park (pl. 2, section $D-D^{\prime}$ ). The approximate extent and thickness of the Grande Ronde unit is shown in figure 9.

Thirty-five of the project wells are completed in the Grande Ronde basalt unit (pl. 2). Based on data from the project wells, the thickness of the unit ranges from 30 to $260 \mathrm{ft}$, with an average thickness of $140 \mathrm{ft}$ (table 2). The depths of the project wells completed in this unit range from 66 to $460 \mathrm{ft}$, with a median depth of $180 \mathrm{ft}$. The estimated horizontal hydraulic conductivity ranges from 0.03 to $13 \mathrm{ft} / \mathrm{d}$, with a median hydraulic conductivity of $2.9 \mathrm{ft} / \mathrm{d}$ (table 2). The driller-reported yields for the Grande Ronde unit ranged from 0.25 to $200 \mathrm{gal} / \mathrm{min}$, with a median yield of $27 \mathrm{gal} / \mathrm{min}$ (table 2). Data are available for only one specific capacity estimate-0.7 (gal/min)/ft (table 2).

\section{Occurrence and Movement of Groundwater}

A general description of the occurrence and movement of groundwater in the Little Spokane River Basin is provided below. It is based largely on the previously described hydrogeologic framework and on water-level measurements made during this investigation from November through December 2011.

\section{Groundwater Occurrence}

Groundwater in the unconsolidated deposits occurs in the pore spaces of the sediment where the sediment is saturated. In the Upper and Lower aquifers, the saturated sediment (sand, gravel) can transmit significant quantities of water, whereas in the Upper and Lower confining units and the Latah unit, the saturated sediment (clay, silt) generally does not transmit significant quantities of water except where sand and gravel lenses occur. Groundwater in the Wanapum and Grande Ronde basalt units occurs in joints, vesicles, fractures, and in the pore spaces of sedimentary interbeds. In the Bedrock unit, groundwater occurs within weathered or fractured zones, and depending on the permeability of the weathered zones and degree of connectedness of the fractures, can transmit usable (for domestic purposes), but generally small, quantities of water. It is important to note that not all units are fully saturated throughout their extent, and in the case of the basin fill units, many are 'bypassed' during drilling, and wells are completed in bedrock.

\section{Groundwater Movement}

Groundwater flow generally is from areas of recharge to areas of discharge, in the direction of decreasing waterlevel altitudes. Recharge from downward percolation of rain and snowmelt can occur at land surface throughout much of the basin, but may be greatest in higher altitude areas where precipitation is greatest and in areas where coarse deposits occur at land surface. Direct precipitation recharges the Upper aquifer over its extent, and streamflow may recharge the aquifer if losing stream reaches directly overlie the aquifer. Groundwater and surface-water relations are uncertain, however, and were not within the scope of this investigation. Significant recharge also may occur along the perimeter of the Upper aquifer, where it is in contact with coarse-grained lenses or landslide deposits within the Upper confining unit. Relatively small amounts of recharge may occur where the Upper aquifer is in contact with springs discharging from productive zones in the basalt or fractured zones within the bedrock. Recharge to the Lower aquifers probably occurs along the valley walls where talus slopes and landslide deposits along basalt bluffs or glacial outwash fans overlie and interfinger with the otherwise continuous confining material. Vertical downward flow through coarse areas of confining units also recharges the Lower aquifers, in places.

Discharge from the groundwater system in the Little Spokane River Basin occurs as pumping from wells, discharge from flowing wells, discharge at springs and seeps, and discharge to the Little Spokane River and its tributaries if groundwater heads are greater than stream stage. Chung (1975) reported that the main stem of the Little Spokane River receives a large amount of groundwater discharge from springs and subsurface seepage, especially along the stream reach between $3 \mathrm{mi}$ north of Chattaroy to $4 \mathrm{mi}$ downstream of Dartford.

Water-level altitudes for the Upper aquifer, Lower aquifers, and Grande Ronde basalt unit are included in figures 7- , respectively, along with generalized directions of groundwater movement. Directions of vertical flow were inferred from water-level altitudes in the Upper aquifer and the Lower aquifers where the units overlie one another. Water-level altitudes in closely spaced wells were reviewed to assess if vertical gradients could be determined. In wells 27N/43E-10B02 and -10B03 near the Colbert Landfill (pl. 1), the difference in water levels was almost $100 \mathrm{ft}$, with a downward gradient from the Upper aquifer to the underlying Lower aquifers. 


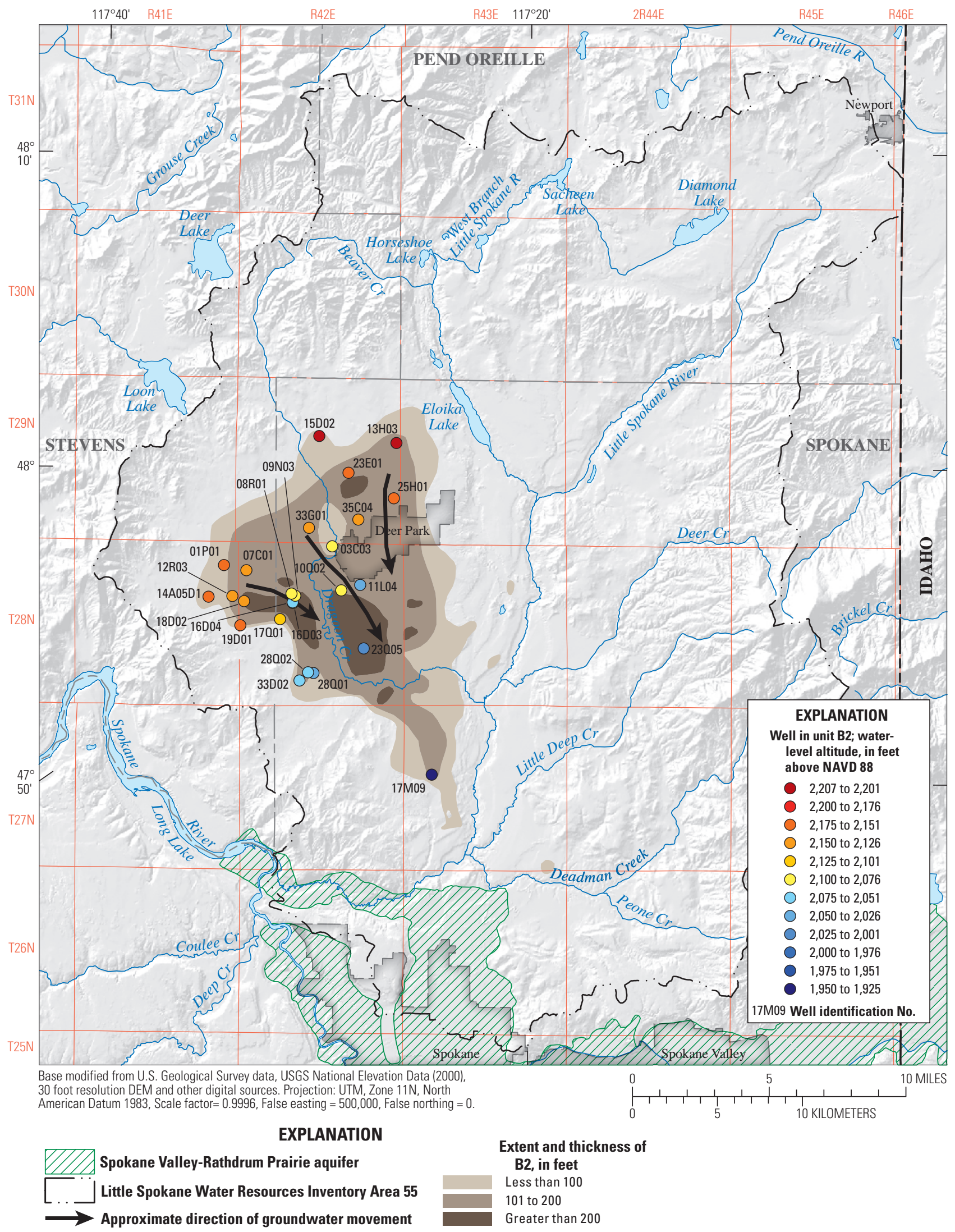

Figure 9. Thickness and extent, and water-level altitudes and inferred directions of groundwater flow of the Grande Ronde basalt unit (B2) in the Little Spokane River Basin, Spokane, Stevens, and Pend Oreille Counties, Washington. 
Generalized water-level altitudes of the entire Little Spokane River Basin groundwater system, including all water levels measured during November-December 2011, are shown in figure 10. Although the general direction of regional groundwater movement can be inferred from these maps of water-level altitudes, it is important to note that these water-level maps are general in nature and indicate regional groundwater conditions and directions of flow. Small-scale local flow patterns may vary greatly, but were not within the scope of this study to define and map. Previous analysis of local groundwater flow patterns is available for some of the subareas within the Little Spokane River Basin in reports discussed in section, Previous Investigations.

Groundwater movement in the Little Spokane River Basin generally mimics the surface-water drainage pattern and topography of the basin. Groundwater flow moves from the topographically high tributary-basin areas toward the topographically lower valley floors (ig. 10). Over the entire basin, water-level altitudes range from more than 2,700 ft to about 1,580 ft near the Little Spokane River at Dartford (USGS streamgage 12431000). Groundwater flow directions near Newport are less certain, but available data indicate a groundwater divide west of Newport with water on one side moving southwest into the Little Spokane River Basin, and water on the other side moving northeast into the Pend Oreille River Basin.

\section{Boundary Conditions}

The groundwater system of the Little Spokane River Basin is bounded laterally and at depth by dense crystalline bedrock. Although the bedrock can supply water from weathered and fractured zones, the unit is expected to be significantly less permeable with depth. In the upper unconfined aquifer, the water table represents an upper boundary. The Lower aquifers are bound by overlying low-permeability sediment and underlying low-permeability sediment, basalt, or bedrock. The rivers and lakes in the basin also act as local boundaries, as zones of discharge or recharge to or from the groundwater system. The lower discharge point of the ground- and surface-water system of the Little Spokane River Basin likely coincides with the location of the USGS Dartford streamgage (12431000) where bedrock crops out at land surface.

\section{Long-Term Water-Level Data}

Although it was outside the scope of this investigation to analyze long-term water-level data, this study provided an opportunity to review 32 long-term water level measurement sites in the Little Spokane River Basin. Future water-use planning and forecasting efforts will rely in part on the use of available long-term data and the understanding of long-term water level patterns. Each site listed in table 3 and shown in figure 11 was field visited to determine the condition of the well, obtain accurate location information, and measure depth to water if possible. Dates of measurements and the name of the agency responsible for those measurements are indicated in table 3 . As of 2012, there are 10 continuous monitoring sites in the basin (fig. 11), which use pressure transducers and data loggers to record the depth to water in each well on a continuous basis. Six wells were destroyed and were no longer measurable (table 3). The wells with the longest period of record (1978-2012) are 28N/43E-16E01 and 29N/42E-33G01 (fig. 11, table 3). 


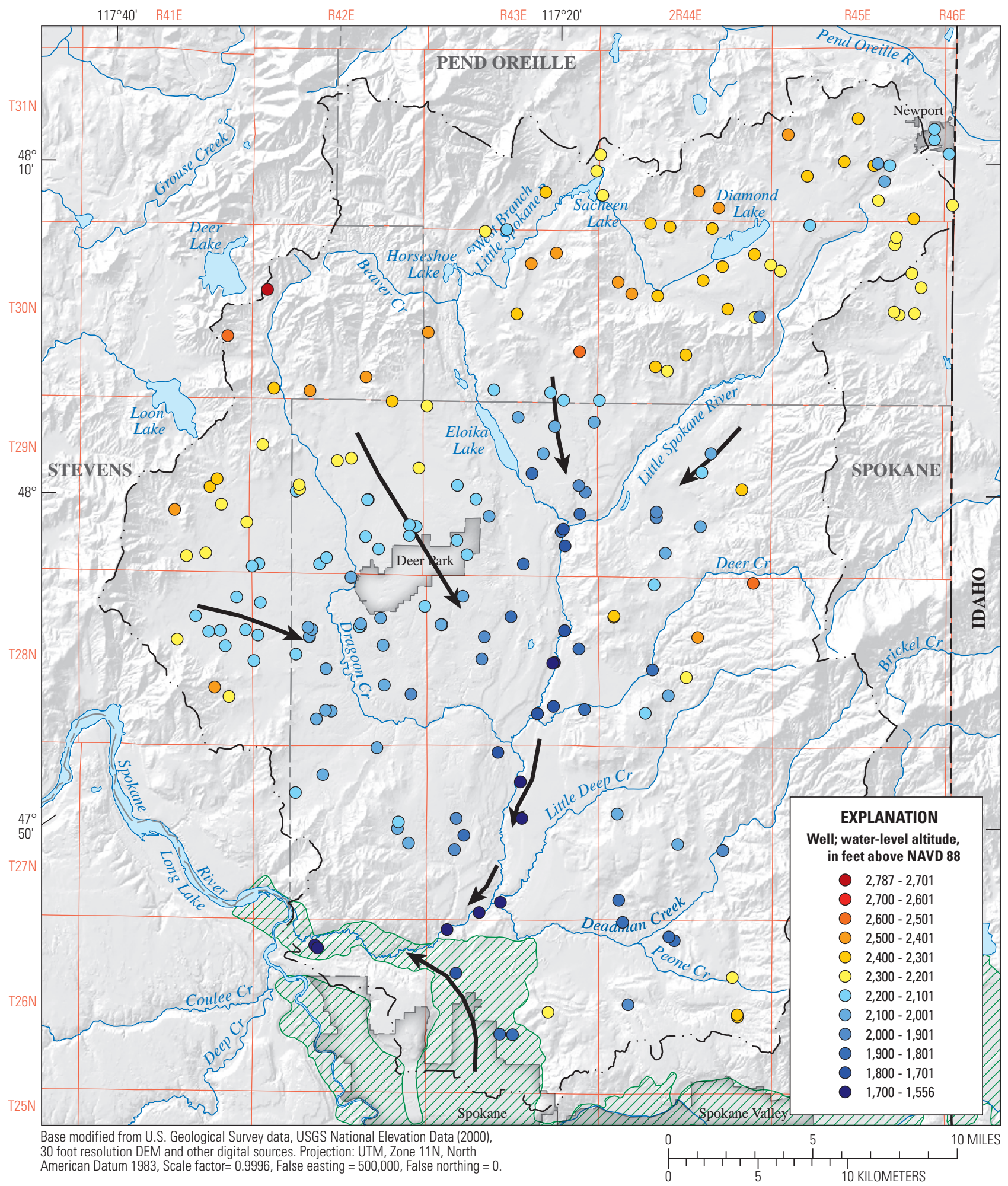

\section{EXPLANATION}

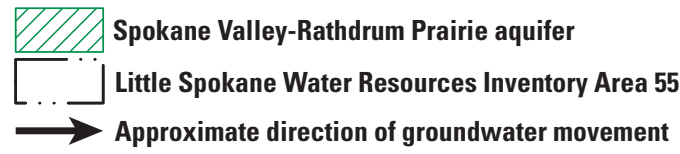

Figure 10. Water-level altitudes and inferred directions of groundwater flow in the Little Spokane River Basin, Spokane, Stevens, and Pend Oreille Counties, Washington. 


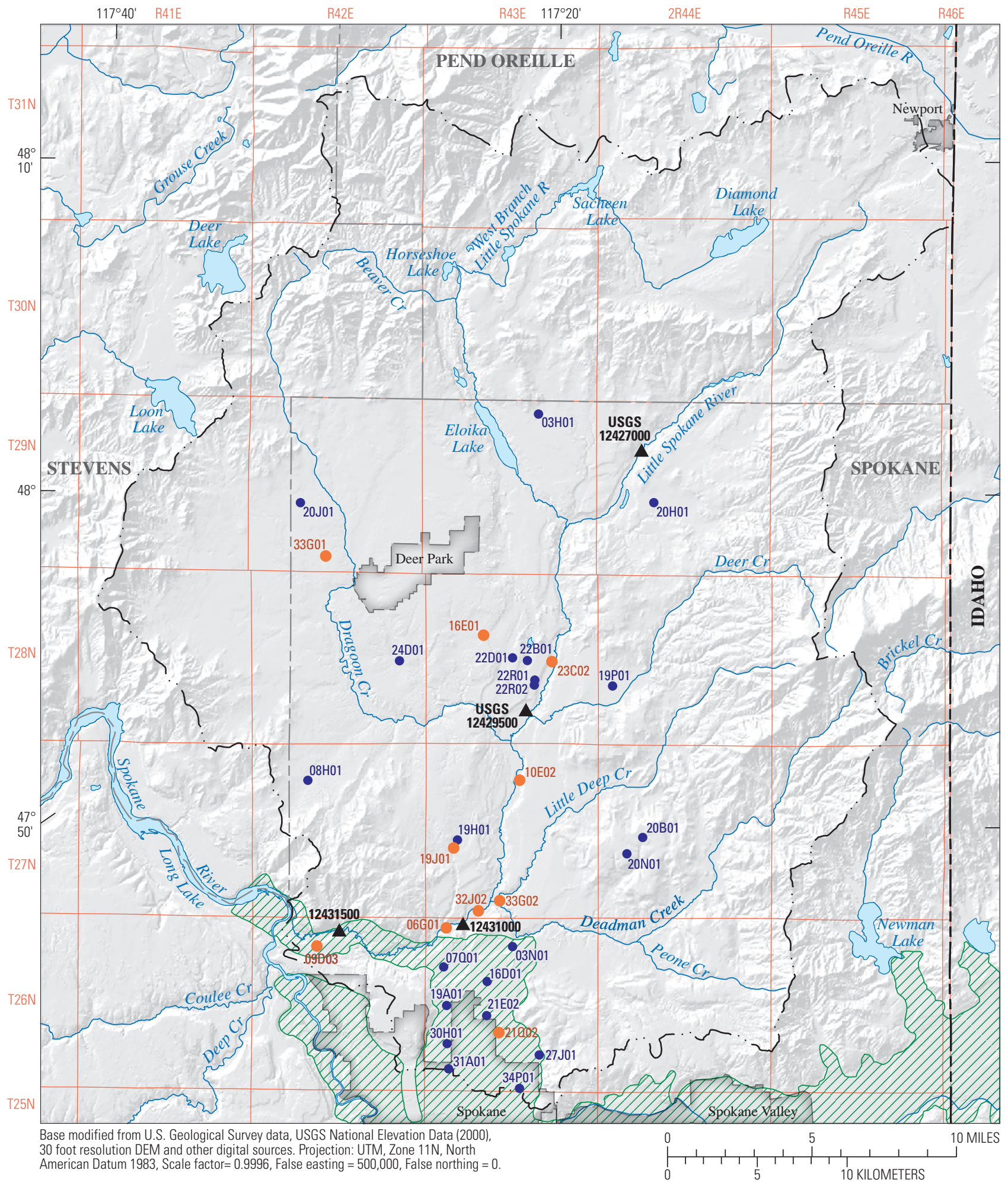

EXPLANATION
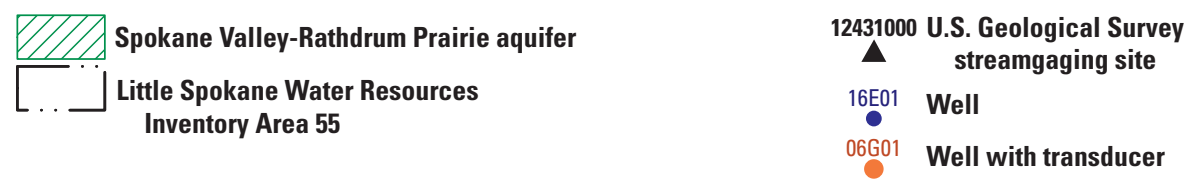

Figure 11. Locations of wells with long-term water level measurements in the Little Spokane River Basin, Spokane, Stevens, and Pend Oreille Counties, Washington. 


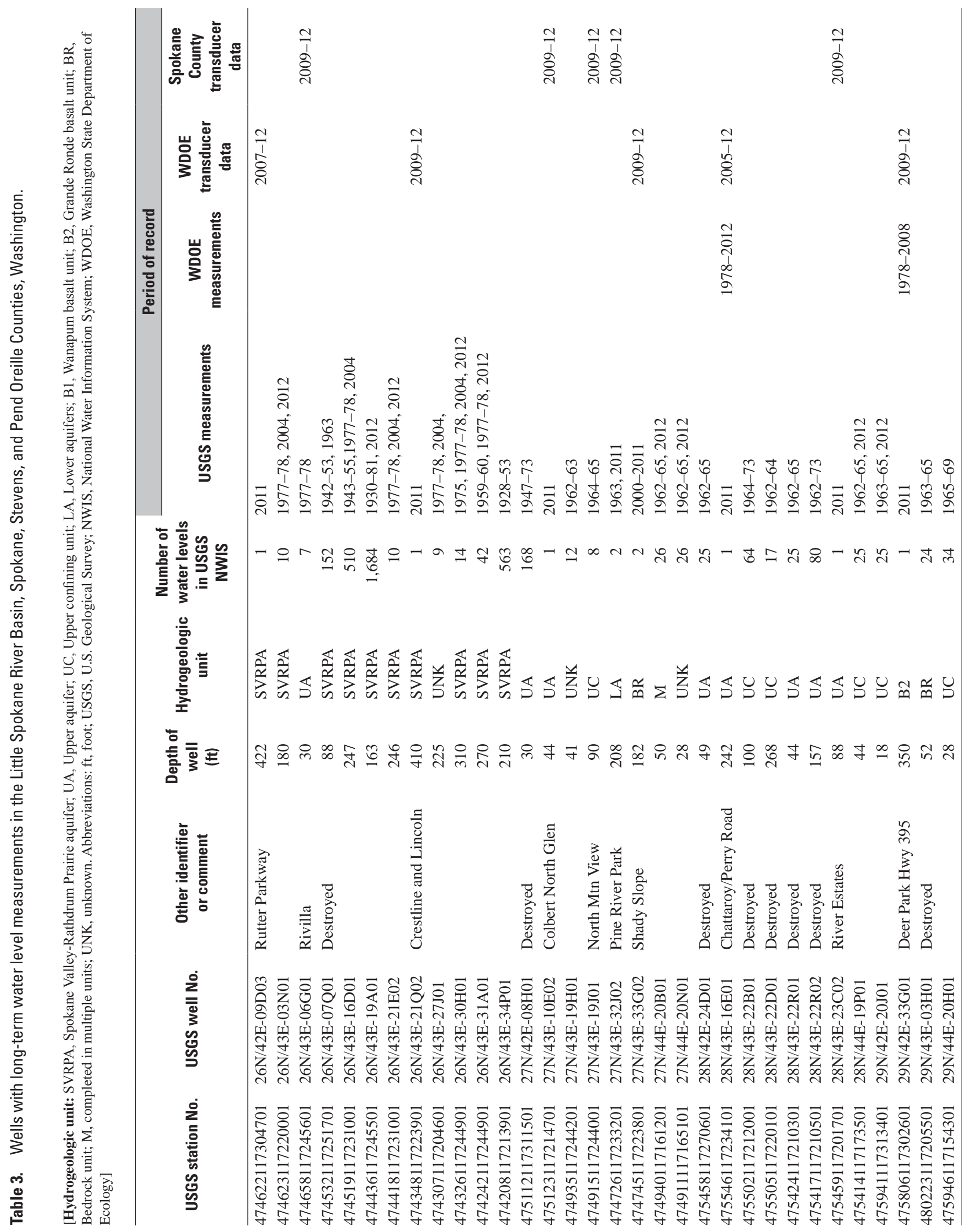




\section{Data Needs}

During the course of this investigation, several data needs were identified that, if filled, would provide a more complete understanding of the hydrogeologic framework of the Little Spokane River Basin. Completion of these tasks could aid in the eventual development of a groundwater surface-water flow model to estimates effects of groundwater use on streamflow and provide managers with a tool to evaluate various groundwater-use scenarios in the basin. Data needs for future research identified during this study are listed below, in no particular order of importance.

- A comparison of the boundary of the Little Spokane Water Resources Inventory Area (WRIA) 55 with the boundary of the Little Spokane River Basin as delineated in the National Watershed Boundary Dataset (U.S. Department of Agriculture, 2012), and an evaluation of possible groundwater and surface-water inputs from the larger area that is not included in WRIA 55 (fig. 12).

- An enhanced definition of the inferred groundwater divide near Newport would provide a better understanding of the boundary conditions at the northeastern extent of the basin.
- A review of existing water-level and streamflow monitoring networks for adequacy of data collection would assure a robust data set for future modeling efforts.

- Measurement of stream discharge throughout the basin during low-flow conditions would help identify gaining and losing stream reaches, and further the understanding of groundwater and surface-water interactions in the basin.

- A compilation and review of available estimates of water use, including Spokane County (2010b), in the basin and further refinements or updates, also will be needed for future modeling and analysis.

- Development of a groundwater budget of the basin would provide water users with a better understanding of this important resource.

- Acquire deep borehole information in areas where they are currently not available, particularly near the outlet of the basin east of Dart Hill. 


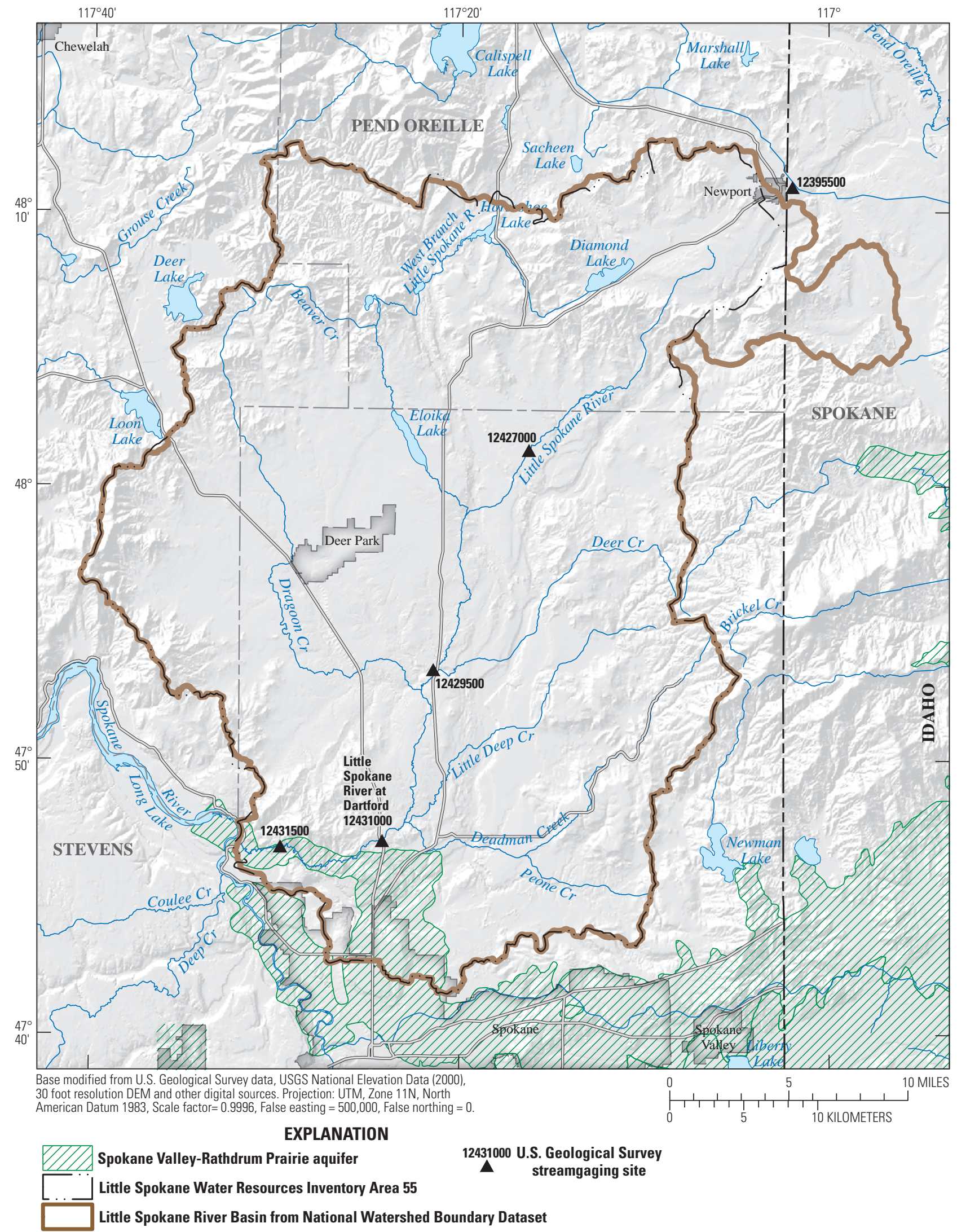

Figure 12. Water Resource Inventory Area 55 in the Little Spokane River Basin, Spokane, Stevens, and Pend Oreille Counties, Washington. (HUC, hydrologic unit code.) 


\section{Summary}

The Little Spokane River Basin includes an area of 679 square miles in northeastern Washington State covering parts of Spokane, Stevens, and Pend Oreille Counties. Streams originate in the northern part of the basin and contribute flow to the Little Spokane River which flows about 49 miles from just south of Newport, Washington, to its confluence with the Spokane River, about 5 miles northwest of the City of Spokane. Precipitation in the Little Spokane River Basin is relatively low, particularly during summer and early autumn. The basin relies on spring snowmelt from the higher elevation areas of the basin and groundwater discharge to the river to maintain streamflows during the drier months.

In 1976, a water resources program for the Little Spokane River was adopted into rule, setting instream flows for the river and closing its tributaries to further uses. Groundwater is an important resource for domestic, commercial, and agricultural use in the Little Spokane River Basin, and groundwater discharge helps maintain streamflow in area streams. The quantity of usable groundwater, and the potential effects of changes in climate or human activities on groundwater resources, as well as potential affects to streamflow, is poorly understood.

An assessment of the hydrogeologic framework of the entire basin was conducted, as a basis for developing an eventual groundwater-flow model that could in turn be used to quantify the effects of groundwater use on the groundwater and surface-water system. Existing geologic and hydrogeologic information was obtained and used to evaluate the hydrogeologic framework of the Little Spokane River Basin. Between November and December 2011, 317 wells throughout the study area were field located to acquire lithologic data and to measure the depth to water in wells; water levels were measurable in 220 wells.

The pre-Tertiary geology includes mostly Precambrian sedimentary rocks that have been metamorphosed and disrupted in places by igneous intrusions. The Tertiary geology includes the remnant Columbia River basalts and interbedded lacustrine deposits of the Latah Formation. The Quaternary geology includes lake, stream, glacial, and catastrophic flood deposits of varying grain size that overlie the older rocks. A digital geologic map compiled for the entire study area includes 11 geologic units-recent non-glacial sediment, mass-wasting deposits, eolian deposits, fine-grained glacial deposits, coarse-grained glacial deposits, glacial till, Wanapum Basalt, Grande Ronde Basalt, Latah Formation, intrusive igneous rocks, and metamorphic rocks.

Based on lithology, areal extent, and general wateryielding properties, eight hydrogeologic units were identified in the study area-Upper aquifer, Upper confining unit, Lower aquifers, Lower confining unit, Wanapum basalt unit, Latah unit, Grande Ronde basalt unit, and Bedrock unit. The
Upper confining unit, Lower confining unit, and the Latah unit are lithologically similar and difficult to differentiate. Conceptually, the hydrogeologic system of the Little Spokane River Basin includes a series of sedimentary deposits and basalt layers, together referred to as basin fill, overlying a 'basin' of crystalline bedrock. The basin fill is composed mostly of low permeability, fine-grained material overlain or interbedded with coarse-grained material (sand and gravel) or basalt.

The Bedrock unit underlies the entire basin, occurs at land surface on about 44 percent of the surface area of the basin and includes granite, quartzite, schist, and gneiss. Although this unit generally yields only small quantities of water from fractured and weathered zones, it is the only available source of water where overlying sediments are absent or insufficiently saturated; 141 of the project wells are completed in this unit. The estimated horizontal hydraulic conductivity ranges from 0.01 to 5,000 feet per day (ft/d), with a median hydraulic conductivity of $1.4 \mathrm{ft} / \mathrm{d}$. The driller reported yields for Bedrock unit wells ranged from 0 (those noted as 'dry') to 60 gallons per minute (gal $/ \mathrm{min}$ ), with a median yield of $4.3 \mathrm{gal} / \mathrm{min}$. A contour map of the approximate altitude of the top of the bedrock indicates that the altitude of the buried bedrock surface ranges from about 2,200 feet to about 1,200 feet. Basin fill is thickest where remnant basalt and Latah Formation overlay bedrock.

The Upper aquifer is composed mostly of sand and gravel with some fine-grained lenses and includes material deposited by glacial meltwater, and glacial outburst floods and streams. The unit varies in thickness from 4 to 360 feet, with an average thickness of 70 feet, and is thickest along former outwash channels, including the channel now occupied by the Little Spokane River, as well as in the Diamond Lake area. The aquifer generally is finer grained in areas farther from main outwash channels. Where the unit is thin and insufficiently saturated, wells penetrate the Upper aquifer and are completed in deeper units. Fifty-seven of the project wells are completed in the unit; the estimated horizontal hydraulic conductivity ranges from 4.4 to $410,000 \mathrm{ft} / \mathrm{d}$, with a median hydraulic conductivity of $900 \mathrm{ft} / \mathrm{d}$. The driller-reported yields for the Upper aquifer wells ranged from 1.0 to $1,300 \mathrm{gal} / \mathrm{min}$, with a median yield of $20 \mathrm{gal} / \mathrm{min}$.

The Upper confining unit is a low-permeability unit consisting mostly of silt and clay with some sand; coarse-grained lenses occur locally. The unit is composed mostly of glaciolacustrine material deposited in ice-dammed lakes, and the distal and fine-grained glacial flood deposits. In places, the unit contains mass-wasting deposits at the base of steep slopes, and lithologically similar but older deposits of the Latah Formation. The Upper confining unit varies in thickness from 5 to 400 feet, with an average thickness of 100 feet. The lateral extent of the unit is difficult to determine due to similarities in lithologic properties between 
the Latah unit and Lower confining unit. Thirty-six of the project wells are completed in the Upper confining unit. The estimated horizontal hydraulic conductivity ranges from 0.5 to $5,600 \mathrm{ft} / \mathrm{d}$, with a median hydraulic conductivity of $8.2 \mathrm{ft} / \mathrm{d}$; driller-reported yields ranged from 2.5 to $75 \mathrm{gal} / \mathrm{min}$, with a median yield of $15 \mathrm{gal} / \mathrm{min}$.

The Lower aquifers unit is composed of localized confined aquifers consisting of sand and some gravel that occurs at depth in various places in the basin but appears to be fairly continuous at depth below the lower reaches of the Little Spokane River. Thirty-six of the project wells are completed in this unit. The thickness of the unit ranges from 8 to 150 feet, with an average thickness of 50 feet.

The Lower confining unit is a low-permeability unit consisting mostly of silt and clay that, in places, underlies the Lower aquifers. The unit may be composed of glaciolacustrine sediment and (or) older Latah Formation sediment. The thickness of the unit ranges from 35 to 310 feet, with an average thickness of 130 feet.

The Wanapum basalt unit includes the Wanapum Basalt of the Columbia River Basalt Group, thin sedimentary interbeds, and, in places, overlying loess. The unit occurs as isolated remnants on the basalt bluffs in the study area. The unit ranges in thickness from 7 to 140 feet, with an average thickness of 60 feet. Only two of the project wells are completed in the Wanapum basalt unit.

The Latah unit is a mostly low-permeability unit consisting of the Latah Formation silt, clay, and sand that underlies and is interbedded with the Grande Ronde and Wanapum Basalts. The unit includes thin or broken basalt and coarse-grained lenses in places, and also may contain lithologically similar but younger glaciolacustrine deposits. The sandy zones of this unit can provide sufficient water for domestic use. Thirty-four of the project wells are completed in this unit. The Latah unit ranges in thickness from 10 to 700 feet, with an average thickness of 250 feet. The estimated horizontal hydraulic conductivity ranges from 0.19 to $15 \mathrm{ft} / \mathrm{d}$, with a median hydraulic conductivity of $0.56 \mathrm{ft} / \mathrm{d}$; driller-reported yields for the unit wells ranged from 3.0 to $100 \mathrm{gal} / \mathrm{min}$, with a median yield of $20 \mathrm{gal} / \mathrm{min}$.

The Grande Ronde unit includes the Grande Ronde Basalt of the Columbia River Basalt Group and sedimentary interbeds, in places. This unit provides sufficient water to numerous domestic wells in the west-central part of the study area from Half Moon Prairie to several miles north of Deer Park. Thirty-five of the project wells are completed in the unit. Unit thickness ranges from 30 to 260 feet, with an average thickness of 140 feet. The estimated horizontal hydraulic conductivity ranges from 0.03 to $13 \mathrm{ft} / \mathrm{d}$, with a median hydraulic conductivity of $2.9 \mathrm{ft} / \mathrm{d}$; driller reported yields ranged from 0.25 to $200 \mathrm{gal} / \mathrm{min}$, with a median yield of $27 \mathrm{gal} / \mathrm{min}$.

Groundwater movement in the Little Spokane River Basin generally mimics the surface-water drainage pattern of the basin, moving from the topographically high tributary-basin areas toward the topographically lower valley floors. Over the entire basin, water-level altitudes range from more than 2,700 feet to about 1,580 feet near the Little Spokane River at Dartford (USGS Station No. 12431000). Groundwater flow directions near Newport are less certain, but available data indicate a possible groundwater divide west of Newport with water on one side moving southwest into the Little Spokane River Basin and water on the other side moving northeast toward the Pend Oreille River Basin.

The groundwater system of the Little Spokane River Basin is bounded laterally and at depth by dense crystalline bedrock. The rivers and lakes in the basin also act as local boundaries, either as zones of discharge or recharge to or from the groundwater system. The lower discharge point of the groundwater and surface-water system of the Little Spokane River Basin likely coincides with the location of the USGS Dartford streamgage (12431000) where bedrock crops out at land surface.

The data needs that were identified during this investigation include better definition of the hydrologic boundaries at the northeast extent of the basin and at the outlet of the basin, a review of existing water-level and streamflow monitoring networks, and an analysis of groundwater and surface water interactions. Finally, a compilation and refinement of available estimates of water use, and the development of a groundwater budget could allow a better understanding of the movement and availability of groundwater in the basin.

\section{Acknowledgments}

The USGS gratefully acknowledges the landowners in the Little Spokane River Basin who allowed access to their land and wells and shared their knowledge about the water resources of the area.

\section{References Cited}

Ader, M.J., 1996, Hydrogeology of the Green Bluff plateau, Spokane County, Washington: Washington State Department of Ecology Open File Technical Report 96-3, 1 v., 28 p.

Anderson, A.L., 1927, Some Miocene and Pleistocene drainage changes in Northern Idaho: Moscow, University of Idaho, Idaho Bureau of Mines and Geology Pamphlet 18, $29 \mathrm{p}$.

Atwater, B.F., 1986, Pleistocene glacial-lake deposits of the Sanpoil River Valley, northeastern Washington: U.S. Geological Survey Bulletin 1661, 39 p. 
Bartolino, J.R., 2007, Assessment of areal recharge to the Spokane Valley-Rathdrum Prairie aquifer, Spokane County, Washington, and Bonner and Kootenai Counties, Idaho: U.S. Geological Survey Scientific Investigations Report 2007-5038, 38 p. (Also available at http://pubs.usgs.gov/ $\underline{\text { sir/2007/5038/.) }}$

Bear, Jacob, 1979, Hydraulics of groundwater: New York, McGraw-Hill, 569 p.

Bjornstad, Bruce, and Kiver, Eugene, 2012, On the trail of the Ice Age floods the northern reaches: Sandpoint, Idaho, Keokee Books, 432 p.

Boese, R.M., 1996, Aquifer delineation and baseline groundwater quality investigation of a portion of north Spokane County, Washington: Cheney, Eastern Washington University Master of Science Thesis, 223 p.

Boleneus, D.E., and Derkey, R.E., 1996, Geohydrology of Peone Prairie, Spokane County, Washington: Washington Geology, v. 24, no. 1, p. 30-39. (Also available at http://www.dnr.wa.gov/Publications/ger washington geology 1996 v24 no1.pdf.)

Burns, E.R., Morgan, D.S., Peavler, R.S., and Kahle, S.C., 2011, Three-dimensional model of the geologic framework for the Columbia Plateau Regional Aquifer System, Idaho, Oregon, and Washington: U.S. Geological Survey Scientific Investigations Report 2010-5246, 44 p. (Also available at http://pubs.usgs.gov/sir/2010/5246).

Campbell, A.M., 2005, Ground-water levels in the Spokane Valley-Rathdrum Prairie aquifer, Spokane County, Washington, and Bonner and Kootenai Counties, Idaho, September 2004: U.S. Geological Survey Scientific Investigations Map 2905, 1 sheet. (Also available at http:// pubs.usgs.gov/sim/2005/2905/.)

Carnahan, B., Luther, H.A., and Wilkes, J.O., 1969, Applied numerical methods: New York, John Wiley and Sons, Inc., $604 \mathrm{p}$.

Carrara, P.E., Kiver, E.P., and Stradling, D.F., 1995, Surficial geologic map of the Chewelah $30^{\prime} \times 60^{\prime}$ quadrangle, Washington and Idaho: U.S. Geological Survey Miscellaneous Investigations Series Map I-2472, 1 sheet, scale 1:100,000.

Carrara, P.E., Kiver, E.P., and Stradling, D.F., 1996, The southern limit of Cordilleran ice in the Colville and Pend Oreille valleys of northeastern Washington during the late Wisconsin glaciation: Canadian Journal of Earth Sciences, v. 33, no. 5, p. 769-778.

Chung, S.K., 1975, Water resources management programLittle Spokane River Basin, WRIA 55: Olympia, Wash., Department of Ecology Policy Development Section, Water Resources Division, 83 p.
Cline, D.R., 1969, Groundwater resources and related geology, north central Spokane and southeastern Stevens Counties, Washington: Washington Department of Water Resources Water Supply Bulletin 27, 195 p., 2 pls.

Conners, J.A., 1976, Quaternary history of northern Idaho and adjacent areas: Moscow, Idaho, University of Idaho, Ph.D. dissertation, $504 \mathrm{p}$.

Dames and Moore, Inc., and Cosmopolitan Engineering Group, 1995, Draft initial watershed assessment Water Resources Inventory Area 55, Little Spokane River watershed: Dames and Moore, Inc., and Cosmopolitan Engineering Group Open-File Technical Report 95-15, 33 p.

Drost, B.W., 2005, Quality-assurance plan for ground-water activities, U.S. Geological Survey, Washington Water Science Center: U.S. Geological Survey Open-File Report 2005-1126, 27 p. (Also available at http://pubs.usgs.gov/ of/2005/1126/.)

EMCON, 1992, Deer Park ground water characterization study, hydrogeologic summary report, v. 1: Bothell, Wash., EMCON Northwest, Inc., project 0622-001.02, 83 p.

Ferris, J.G., Knowles, D.B., Brown, R.H., and Stallman, R.W., 1962, Theory of aquifer tests: U.S. Geological Survey Water-Supply Paper 1536-E, 174 p.

Freeze, R.A., and Cherry, J.A., 1979, Groundwater: Englewood Cliffs, New Jersey, Prentice-Hall, 604 p.

Golder Associates, Inc., 2003, Little Spokane (WRIA 55) and Middle Spokane (WRIA 57) watershed planning phase IILevel 1 assessment, data compilation and analysis: Seattle, Golder Associates, Inc., prepared under grant no. 9800300 from the Washington Department of Ecology, variously paginated.

Golder Associates, Inc., 2004, Final report to the Little and Middle Spokane watershed WRIA 55 and 57 planning unit, level 2 technical assessment-Watershed simulation model: Seattle, Golder Associates, Inc., prepared under grant no. 9800300, from the Washington Department of Ecology, 51 p., 4 appendixes.

Google ${ }^{\mathrm{TM} E a r t h}, 2011$, Satellite imagery, maps, and terrain: Google Earth website, accessed November 2011, at http:// earth.google.com/index.html.

Hsieh, P.A., Barber, M.E., Contor, B.A., Hossain, Md.A., Johnson, G.S., Jones, J.L., and Wylie, A.H., 2007, Groundwater flow model for the Spokane Valley-Rathdrum Prairie Aquifer, Spokane County, Washington, and Bonner and Kootenai Counties, Idaho: U.S. Geological Survey Scientific Investigations Report 2007-5044, 78 p. (Also available at http://pubs.usgs.gov/sir/2007/5044/.) 
Kahle, S.C., and Bartolino, J., 2007, Hydrogeologic framework and water budget of the Spokane ValleyRathdrum Prairie Aquifer, Spokane County, Washington and Bonner and Kootenai Counties, Idaho: U.S. Geological Survey Scientific Investigations Report 2007-5041, 48 p. (Also available at http://pubs.usgs.gov/sir/2007/5041/.)

Kahle, S.C., Caldwell, R.R., and Bartolino, J.R., 2005, Compilation of geologic, hydrologic, and ground-water flow modeling information for the Spokane Valley—Rathdrum Prairie Aquifer, Spokane County, Washington, and Bonner and Kootenai Counties, Idaho: U.S. Geological Survey Scientific Investigations Report 2005-5227, 64 p. (Also available at http://pubs.usgs.gov/sir/2005/5227/.)

Kahle, S.C., Longpré, C.I., Smith, R.R., Sumioka, S.S., Watkins, A.M., and Kresch, D.L., 2003, Water resources in the groundwater system in unconsolidated deposits of the Colville River watershed, Stevens County, Washington: U.S. Geological Survey Water-Resources Investigations Report 03-4128, 76 p. (Also available at http://pubs.usgs. gov/wri/wri034128/.)

Kahle, S.C., Morgan, D.S., Welch, W.B., Ely, D.M., Hinkle, S.R., Vaccaro, J.J., and Orzol, L.L., 2011, Hydrogeologic framework and hydrologic budget components of the Columbia Plateau Regional Aquifer System, Washington, Oregon, and Idaho: U.S. Geological Survey Scientific Investigations Report 2011-5124, 66 p. (Also available at http://pubs.usgs.gov/sir/2011/5124/.)

Kahle, S.C., Taylor, W.A., Lin, Sonja, Sumioka, S.S., and Olsen, T.D., 2010, Groundwater and surface-water systems, land use, pumpage, and water budget of the Chamokane Creek basin, Stevens County, Washington: U.S. Geological Survey Scientific Investigations Report 2010-5165, 60 p. (Also available at http://pubs.usgs.gov/sir/2010/5165/.)

Kiver, E.P., and Stradling, D.F., 1982, Quaternary geology of the Spokane area, in Roberts, S., and Fountain, D., eds., 1980 Field Conference Guidebook: Spokane, Wash., Tobacco Root Geological Society, p. 26-44.

Kiver, E.P., and Stradling, D.F., 2001, Ice age floods in the Spokane and Cheney area, Washington-Field trip guide, October 20, 2001: Cheney, Wash., Ice Age Floods Institute, $48 \mathrm{p}$.

Kiver, E.P., Stradling, D.F., and Moody, U.L., 1989, Glacial and multiple flood history of the northern borderlands-Trip B, in Joseph, N.L., and others, eds., Geologic guidebook for Washington and adjacent areas: Washington Division of Geology and Earth Resources Information Circular 86, p. 321-335.
Landau Associates, Inc., and others, 1991, Colbert landfill remedial design/remedial action, Spokane County, Washington, Volume I of III-Final phase I engineering report: Landau Associates, Inc., (under contract to) Spokane County, Washington, $1 \mathrm{v}$.

Lasmanis, R., 1991, The Geology of Washington: Rocks and Minerals, v. 66, no. 4, p. 262-277.

McDonald, E.V., and Busacca, A.J., 1992, Late Quaternary stratigraphy of loess in the Channeled Scabland and Palouse regions of Washington State: Quaternary Research, v. 38, p. $141-156$.

Miller, F.K., 2000, Geologic map of the Chewelah 30' X $60^{\prime}$ quadrangle, Washington and Idaho: U.S. Geological Survey Miscellaneous Field Studies MF-2354, accessed November 2011, at http://pubs.usgs.gov/mf/2001/2354/.

Pend Oreille County Assessor, 2011, Pend Oreille County Real Property Search: Pend Oreille County, database, accessed November 2011 at http://www.pendoreilleco.org/county/ assessor.asp.

Richmond, G.M., Fryxell, R., Neff, G.E., and Weis, P.L., 1965, The Cordilleran ice sheet of the northern Rocky Mountains, and the related Quaternary history of the Columbia Plateau, in Wright, H.E., Jr., and Frey, D.G., eds., The Quaternary of the United States: Princeton, N.J., Princeton University Press, p. 231-242.

Spokane County, 2006, Watershed Management Plan Water Resources Area 55-Little Spokane River and Water Resources Area 57-Middle Spokane River: Little Spokane and Middle Spokane River Planning Unit, 120 p.

Spokane County, 2009, WRIA 55 (Little Spokane River) Groundwater Inventory and Mapping Project, June 2009, prepared for WRIA 55/57 Watershed Implementation Team: Spokane, Wash., Spokane County Water Resources, 16 p.

Spokane County, 2010a, Little Spokane Groundwater Elevation and Stream Flow Monitoring Project, June 30, 2010, prepared for WRIA 55/57 Watershed Implementation Team: Spokane, Wash., Spokane County Water Resources, $52 \mathrm{p}$.

Spokane County, 2010b, Spokane County Residential Water Use Survey, prepared for WRIA 55/57 Watershed Implementation Team and WRIA 56 Watershed Implementation Team: Spokane, Wash., Spokane County Water Resources, variously paged. 
Spokane County, 2011, Little Spokane Groundwater Elevation and Stream Flow Monitoring Project Technical Memorandum-2011 Project Update, June 30, 2011, prepared for WRIA 55/57 Watershed Implementation Team: Spokane, Wash., Spokane County Water Resources, variously paged.

Spokane County Assessor, 2011, Spokane County Parcel Information Search: Spokane County database, accessed November 2011 at http://www.spokanecounty.org/pubpadal/ Search.aspx.

Spokane County Conservation District, 2010, Little Spokane River Stream Gage Report—Deadman Creek, Dragoon Creek, and the West Branch of the Little Spokane River: Spokane, Wash., Spokane County Conservation District, $9 \mathrm{p}$.

Stevens County Assessor, 2011, Parcel Data Base Information System and Assessor's Maps: Stevens County database, accessed November 2011 at http://stevenswa.taxsifter.com/ Search/Results.aspx.

Stoffel, K.L., Joseph, N.L., Waggoner, S.Z., Gulick, C.W., Korosec, M.A., and Bunning, B.B., 1991, Geologic map of Washington northeast quadrant: Washington Division of Geology and Earth Resources, Geologic map GM-39, scale 1:250,000.

U.S. Department of Agriculture, 2012, Natural Resources Conservation Service Watershed Boundary Dataset: U.S. Department of Agriculture, accessed November 1, 2012, at http://www.nrcs.usda.gov/wps/portal/nrcs/detail/national/ technical/nra/dma/?\&cid=nrcs143 021630.

U.S. Forest Service, 2010, Ice Age floods in the Pacific Northwest [poster]: U.S. Forest Service, modified by the Ice Age Flood Institute and Eastern Washington University.

U.S. Geological Survey, 2009, Water resources of the United States, 2009: U.S. Geological Survey Water-Data Report WDR-US-2009. (Also available at http://wdr.water.usgs. gov/wy2009/search.jsp).
Waitt, R.B., Jr., 1980, About forty last-glacial Lake Missoula jökulhlaups through southern Washington: Journal of Geology, v. 88, p. 653-679.

Waitt, R.B., Jr., and Thorson R.M., 1983, The Cordilleran ice sheet in Washington, Idaho, and Montana, in Wright, H.E., and Porter, S.C., eds., Late-Quaternary environments of the United States, v. 1: Minneapolis, University of Minnesota Press, p. 53-70.

Washington State Division of Geology and Earth Resources, 2005, Digital 1:100,000-scale geology of Washington State, ver. 1.0: Washington Division of Geology and Earth Resources database, accessed February 1, 2012, at http:// www.dnr.wa.gov/ResearchScience/Topics/GeosciencesData/ Pages/gis data.aspx.

Washington State Department of Ecology, 1988, Updated Chapter 173-555 WAC Water Resources Program in the Little Spokane River Basin, WRIA 55: Washington State Department of Ecology, 6 p., accessed May 8, 2013, at http://www.ecy.wa.gov/pubs/wac173555.pdf.

Washington State Department of Ecology, 2012, Focus on water availability, Little Spokane watershed: Washington State Department of Ecology, WRIA 55: Washington State Department of Ecology Fact Sheet 11-11-059, 5 p., accessed September 1, 2012, at https://fortress.wa.gov/ecy/ publications/publications/1111059.pdf.

Zientek, M.L., Derkey, P.D., Miller, R.J., Causey, J.D., Bookstrom, A.A., Carlson, M.H., Green, G.N., Frost, T.P., Boleneus, D.E., Evans, K.V., Van Gosen, B.S., Wilson, A.B., Larsen, J.C., Kayser, H.Z., Kelley, W.N., and Assmus, K.C., 2005, Spatial databases for the geology of the Northern Rocky Mountains-Idaho, Montana, and Washington: U.S. Geological Survey Open-File Report 2005-1235, 201 p., at http://pubs.usgs.gov/of/2005/1235/. 


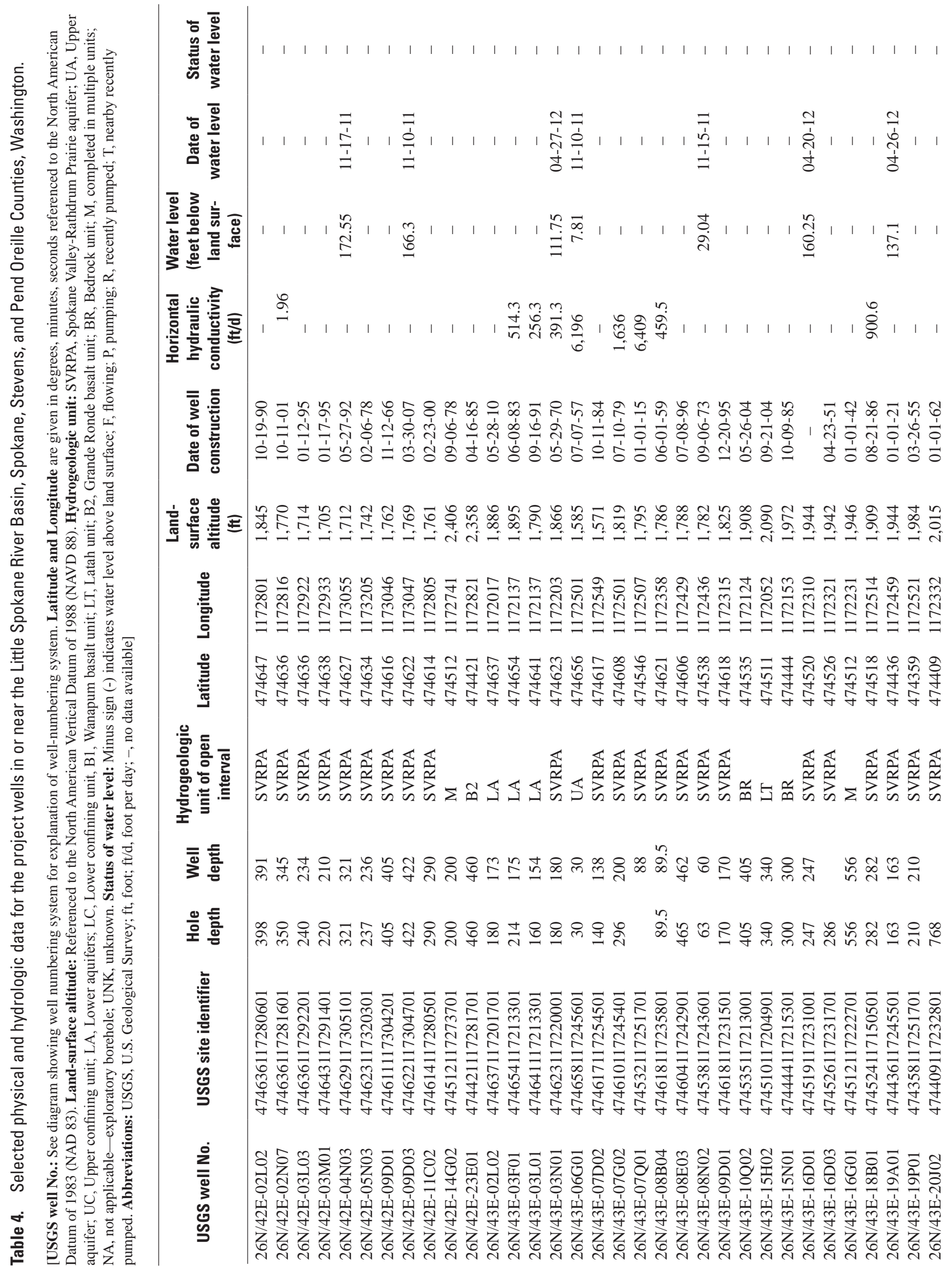



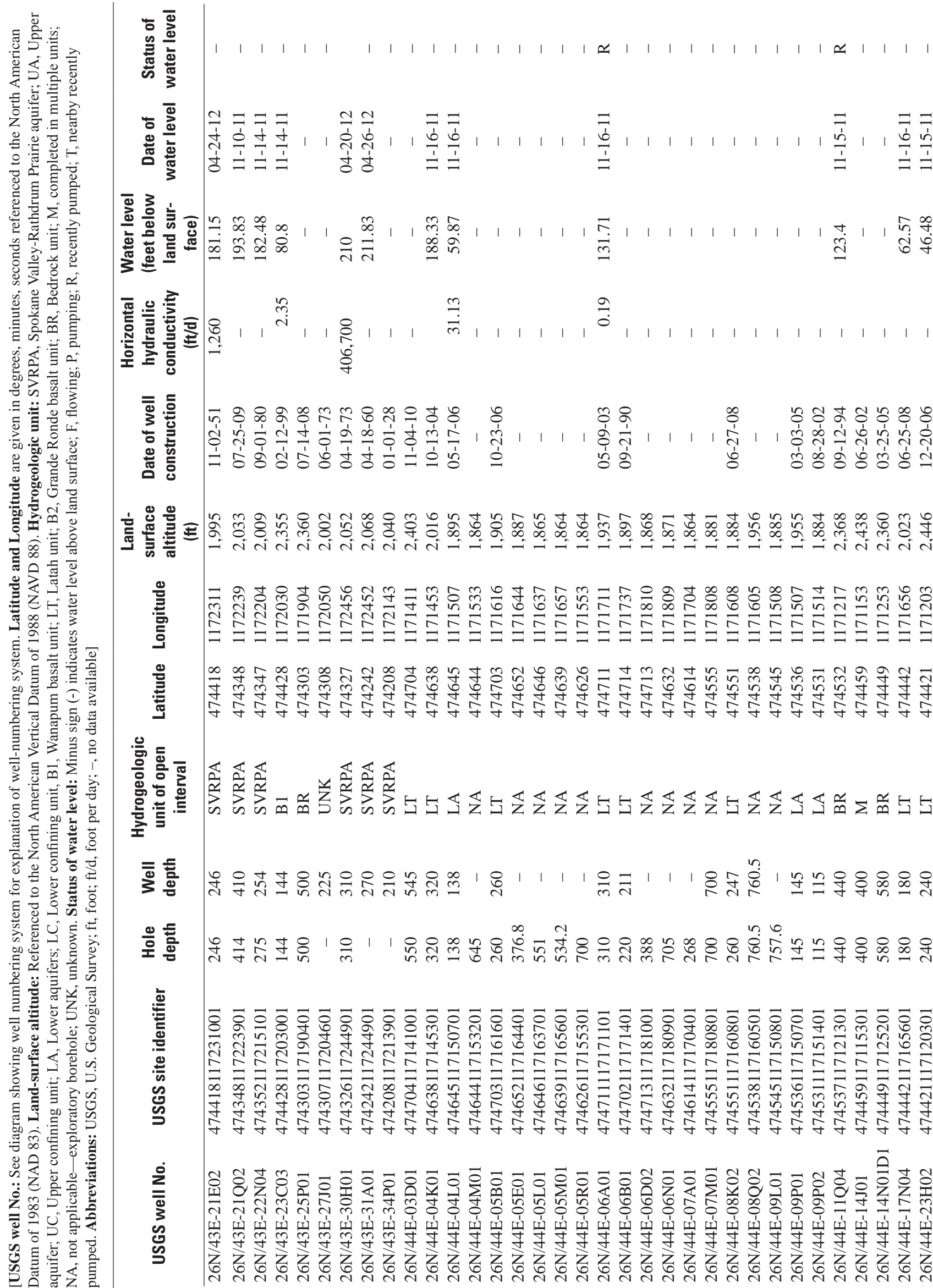

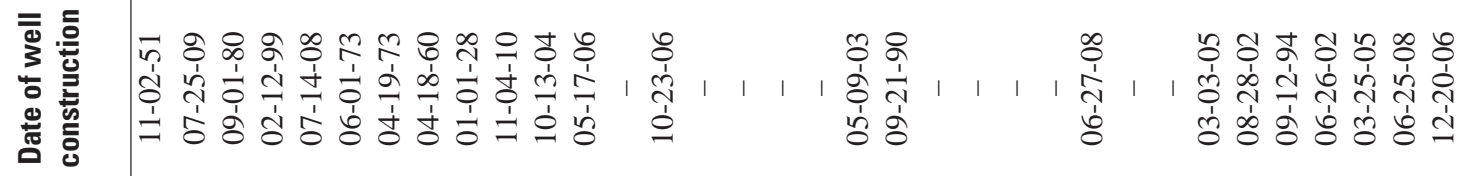

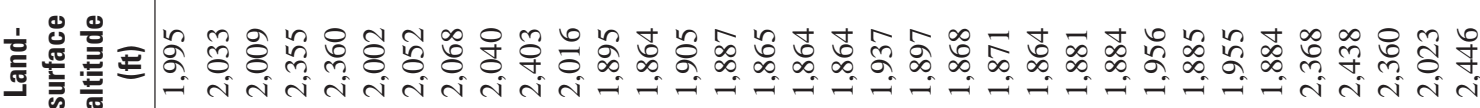

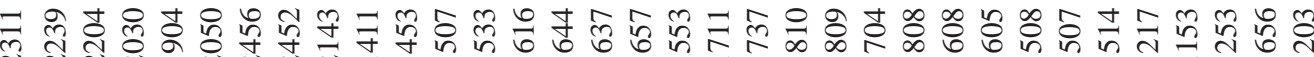

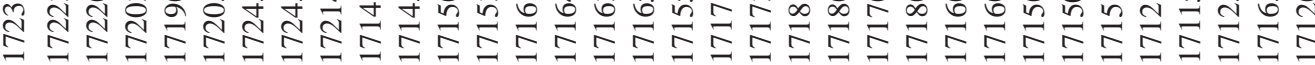
த

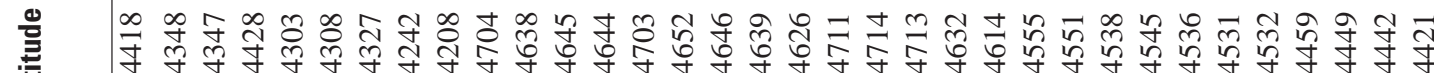

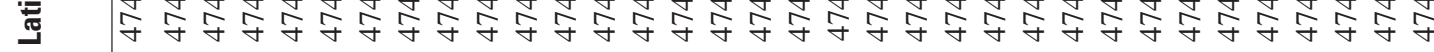

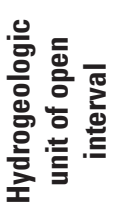

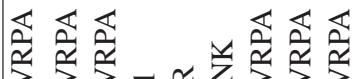

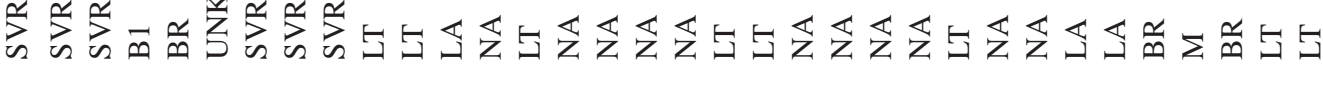

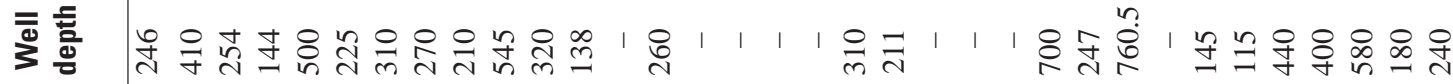

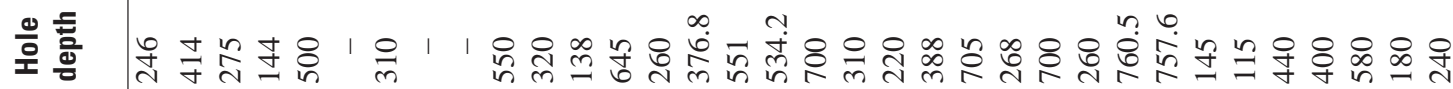

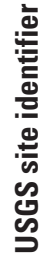

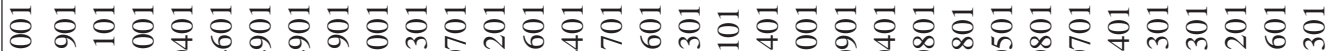

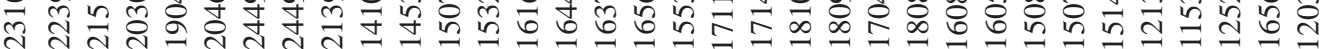

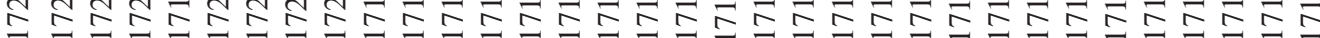

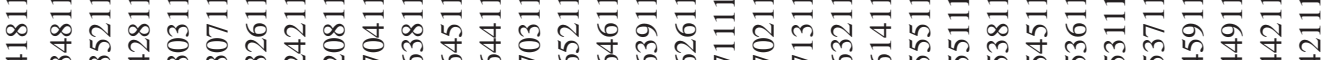

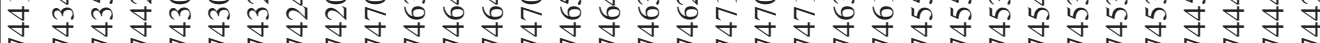

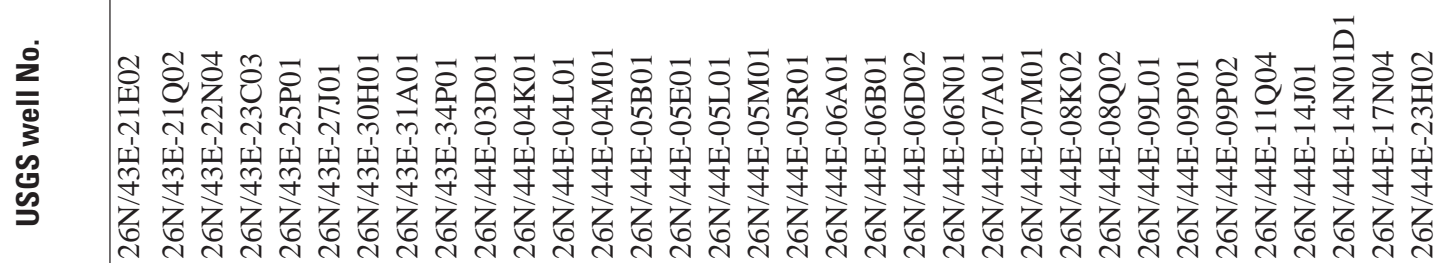




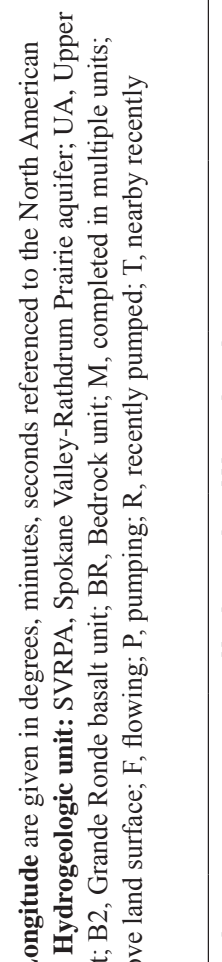

항ㅎㅇ

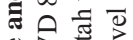

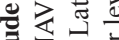

己㐫

$\infty_{\infty}^{\infty}, 3$

घं山्ञ

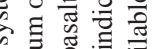

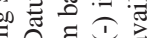

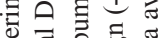

त्व

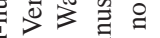

苍焉节密

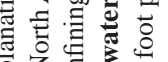

肴

क्षे

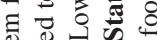

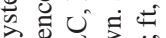

की

恶焉悬

을 要 定 zo

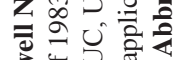
जी:

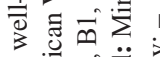

安

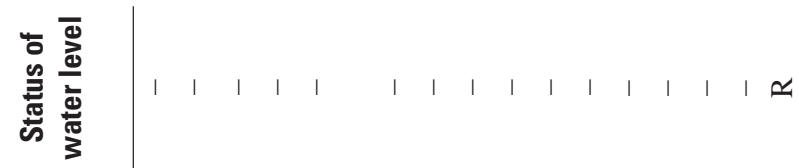

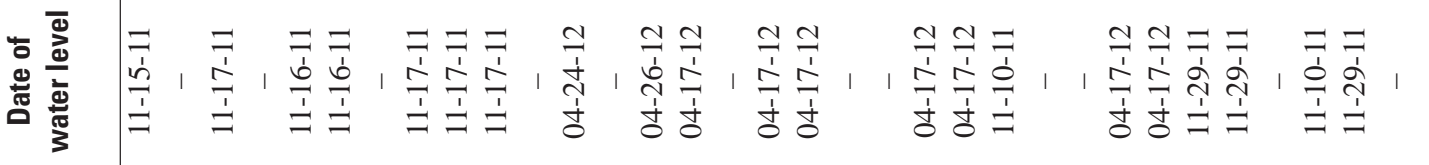

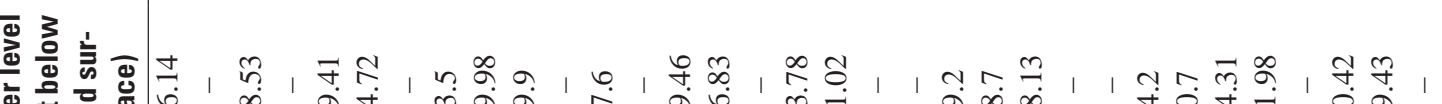

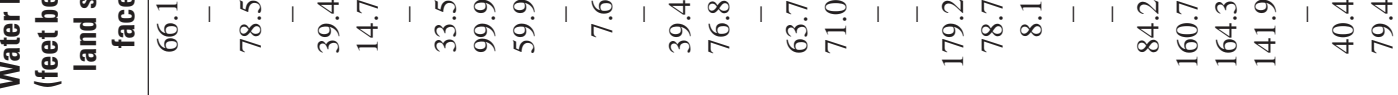

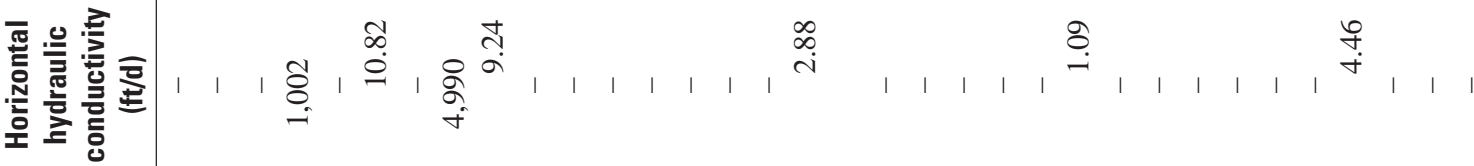

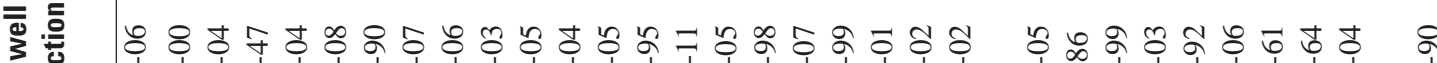

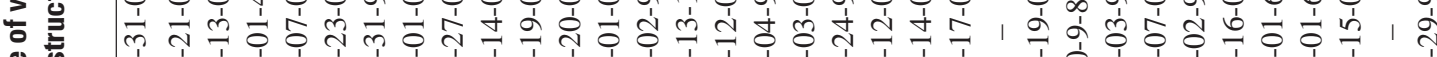

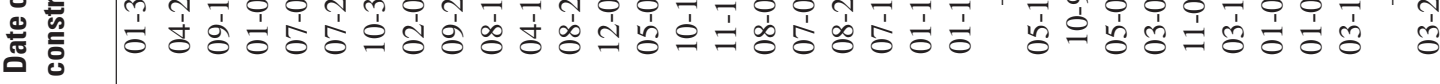

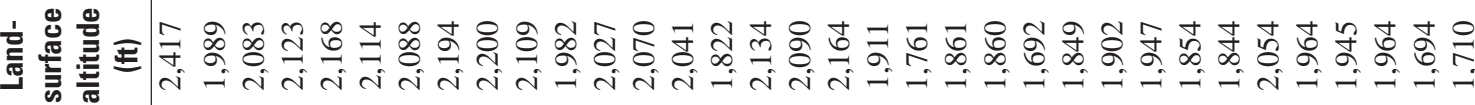

임

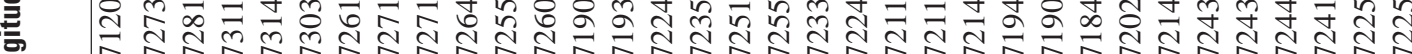

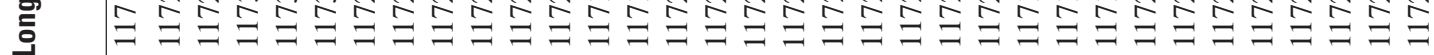

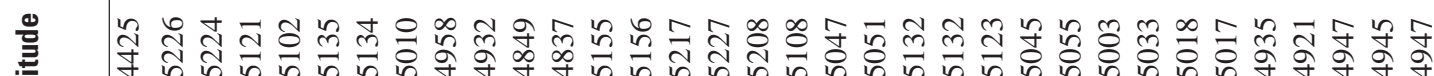

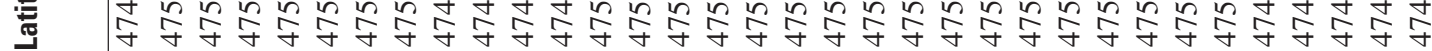
능 $=$

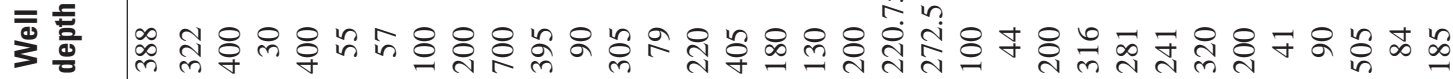

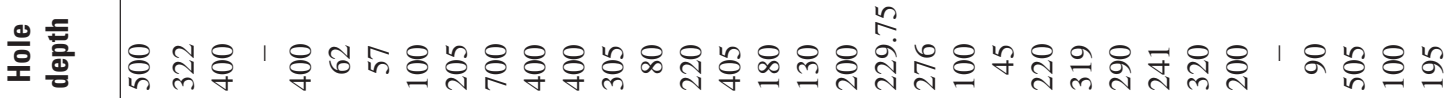
êd

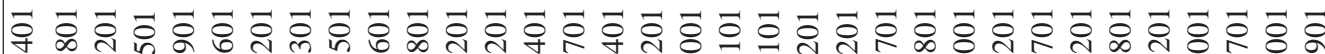

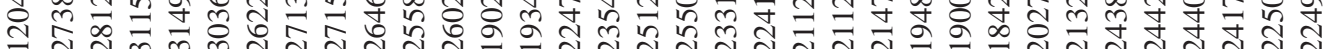

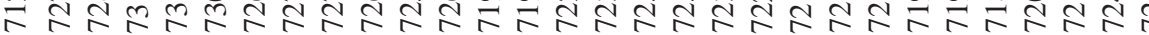

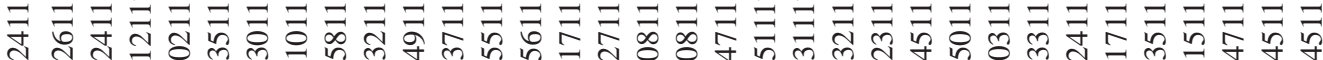

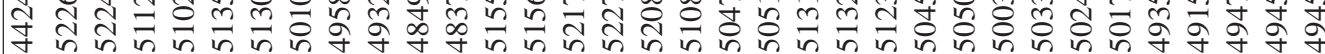

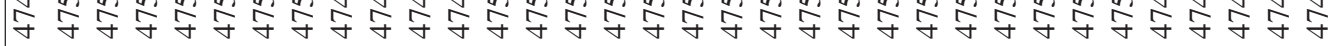

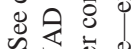
空

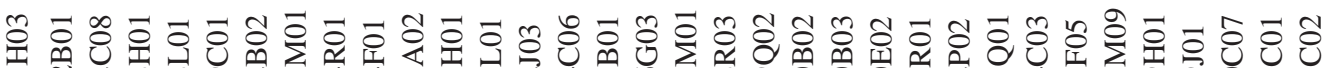
议

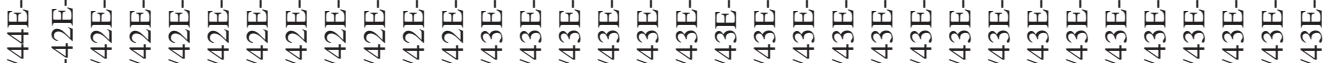

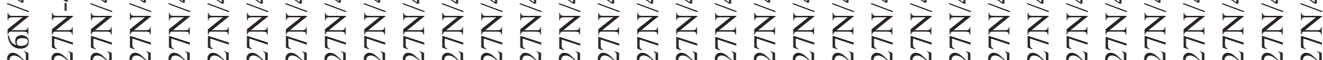



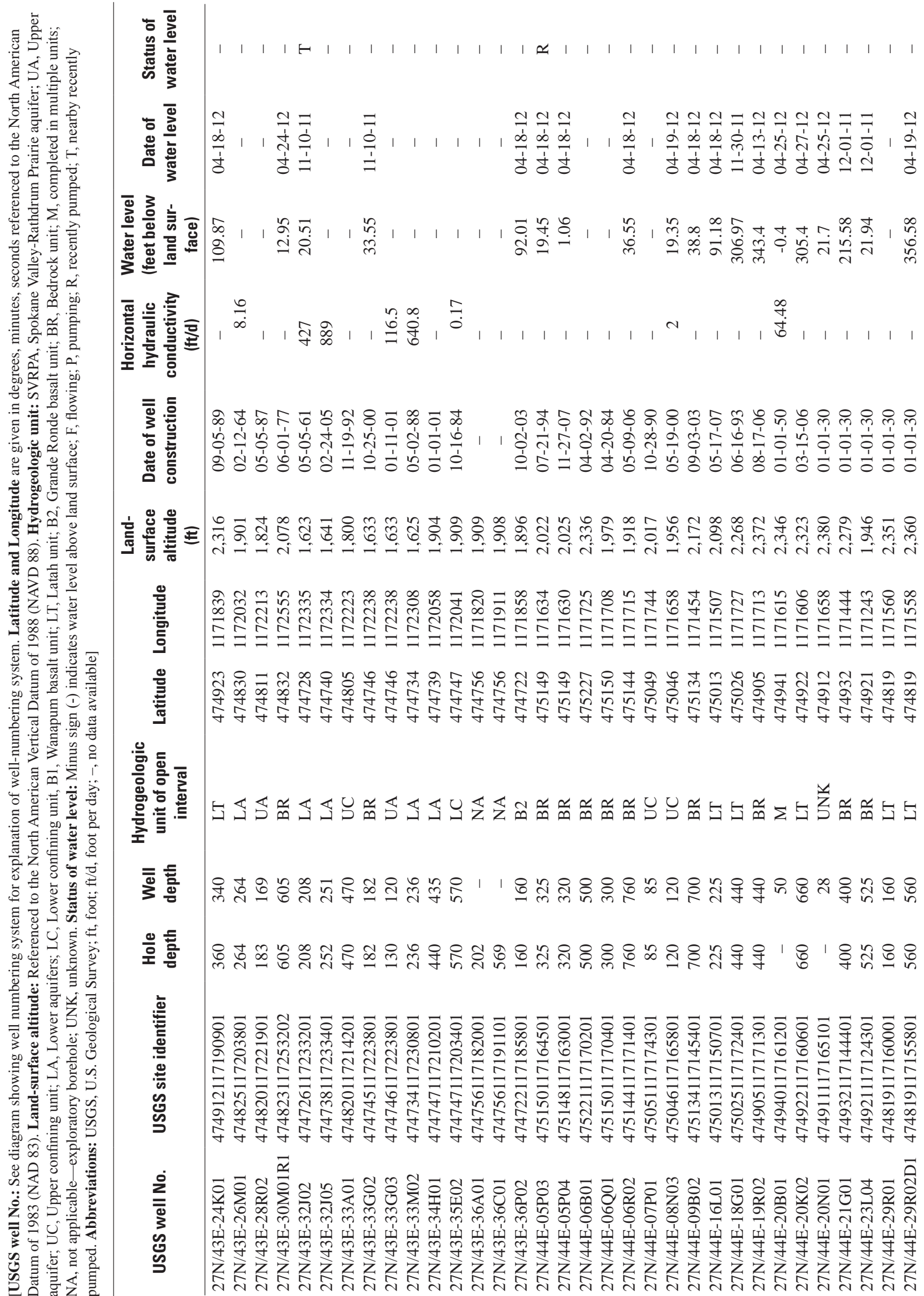

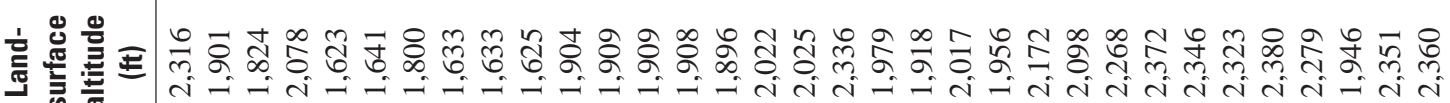

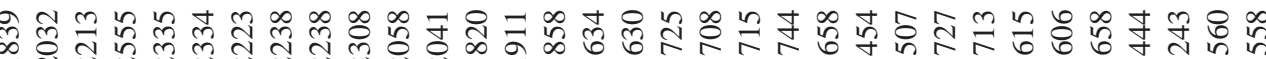

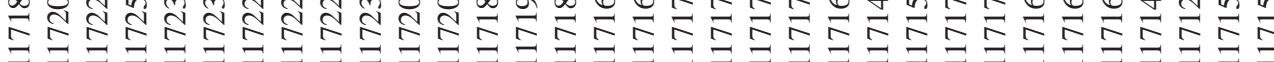

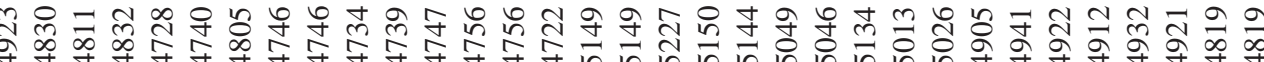

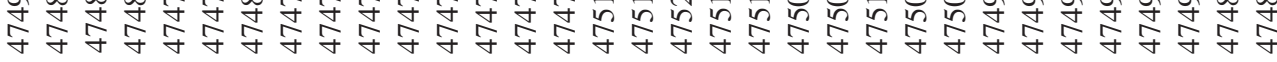

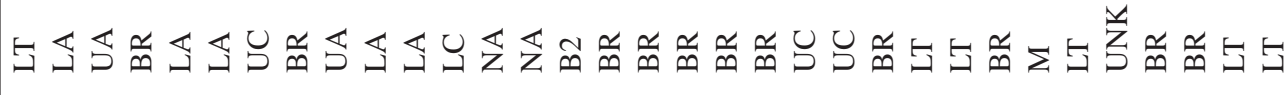

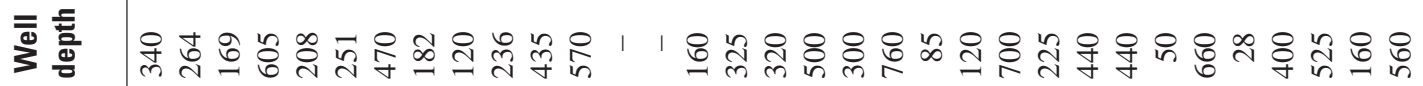

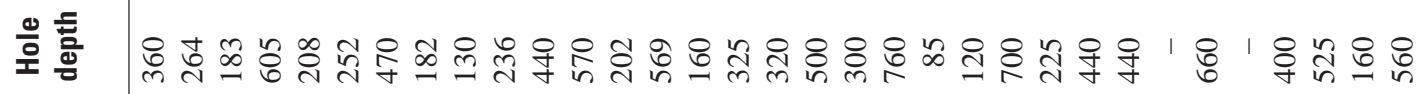

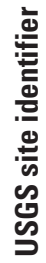

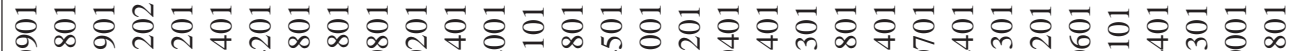

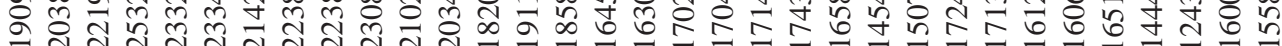

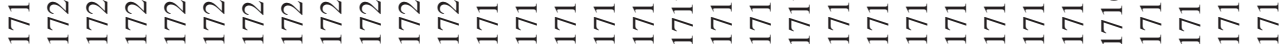

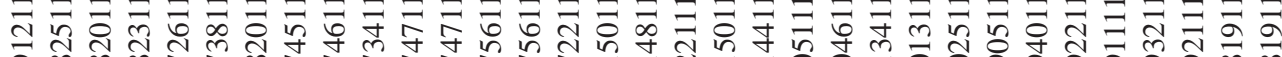

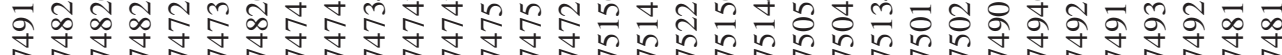

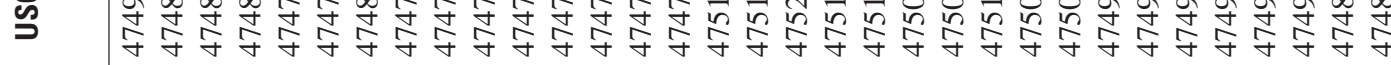

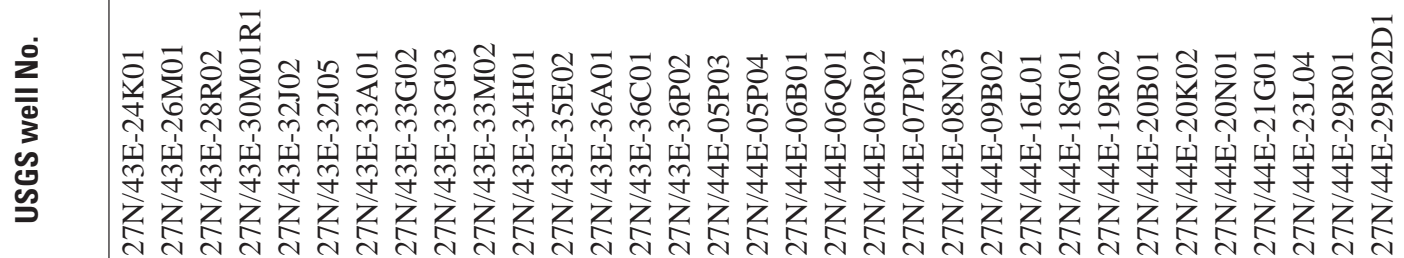



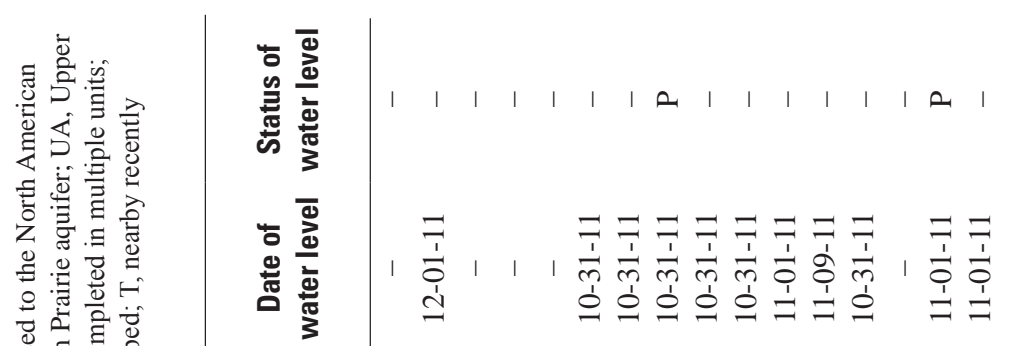

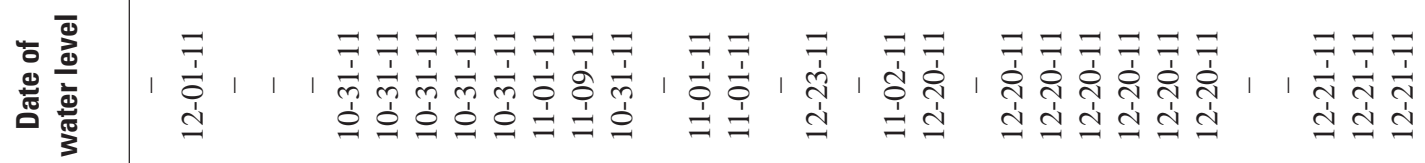

छ ठำ

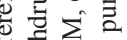

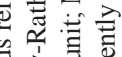

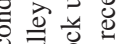

is

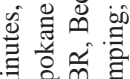

自的恋

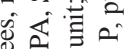

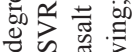

in

专

$\sum_{\mathrm{D}} \mathrm{\Omega}$

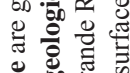

है

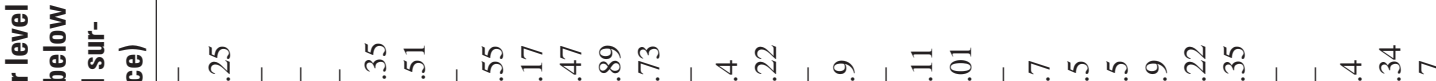

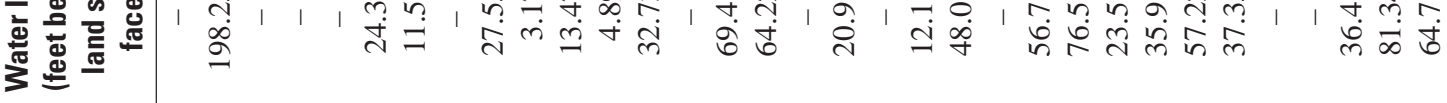
定品

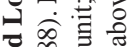

$\rho$ 的

安焉要

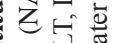

品.

要要

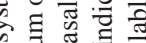

no

完

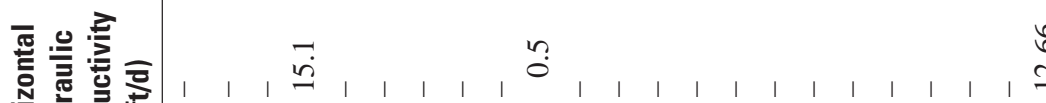

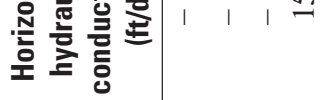

تิ

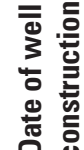

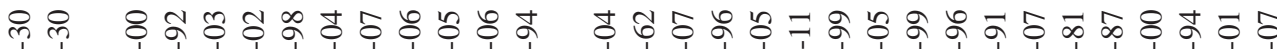

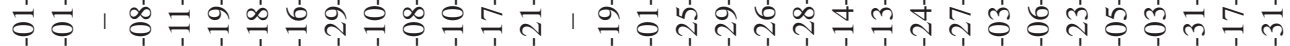

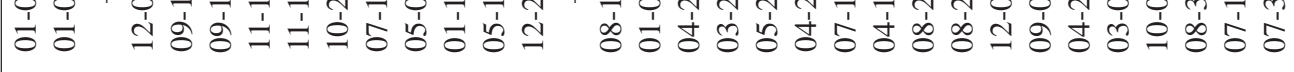

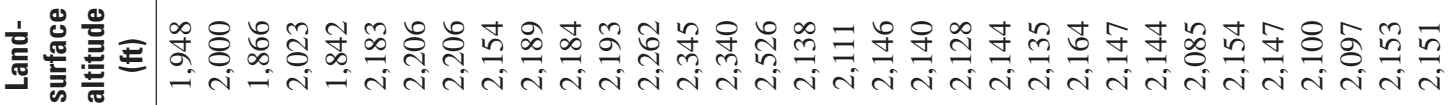

产

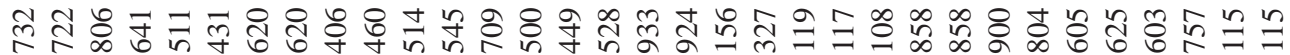

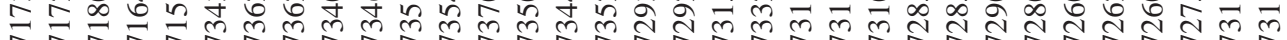

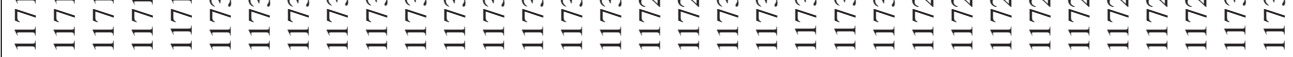

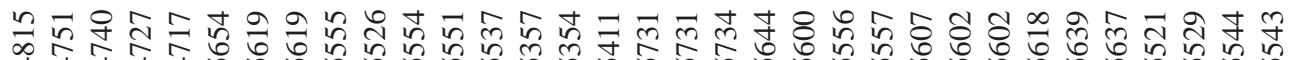

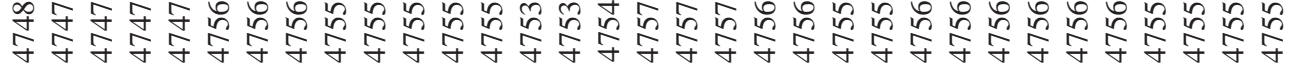

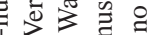

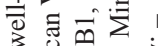

บ보 专

守导萌品 \&

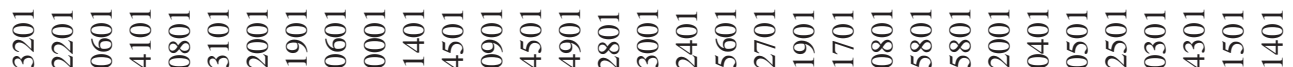
N

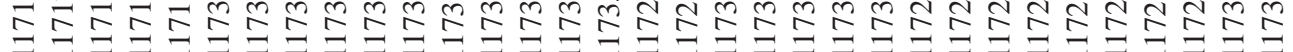

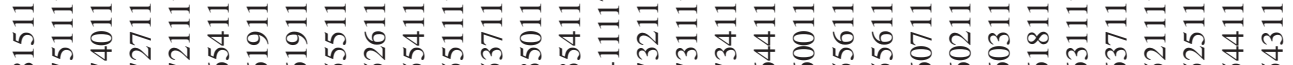

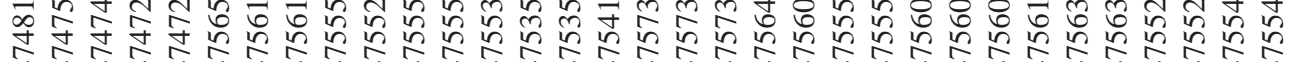

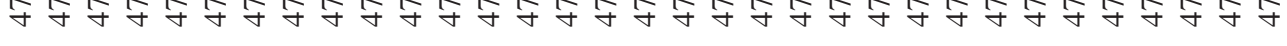

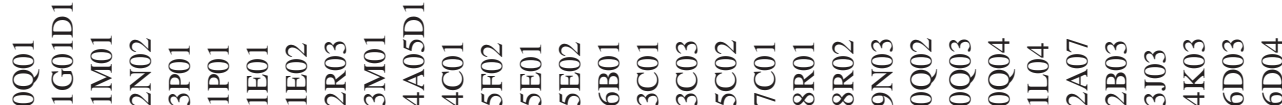

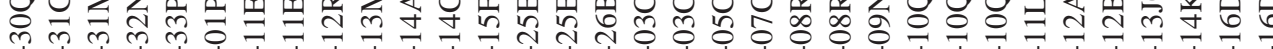

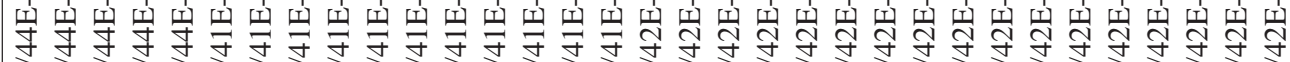

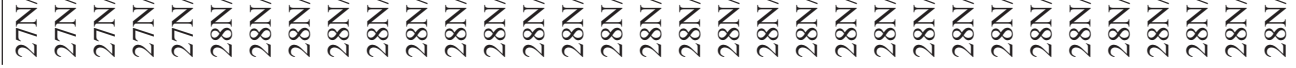



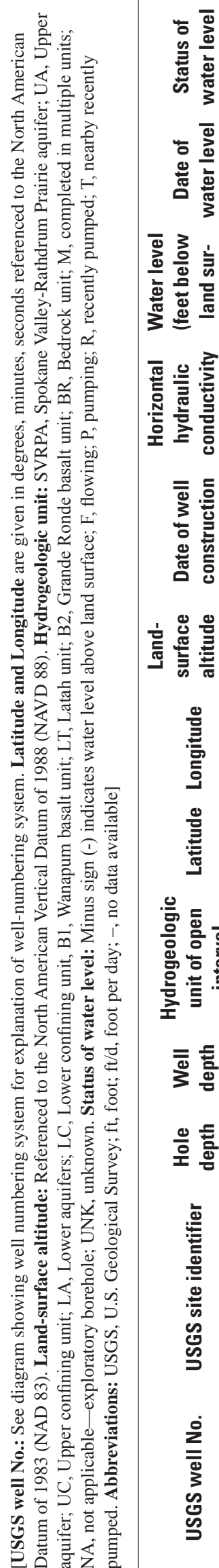

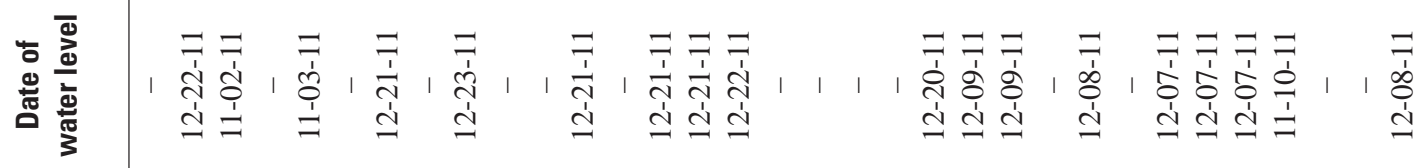

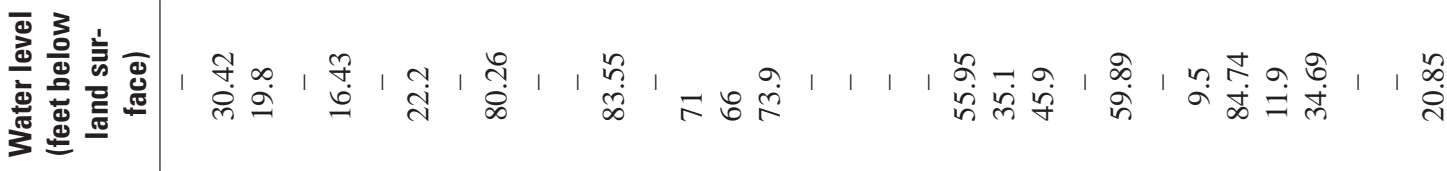

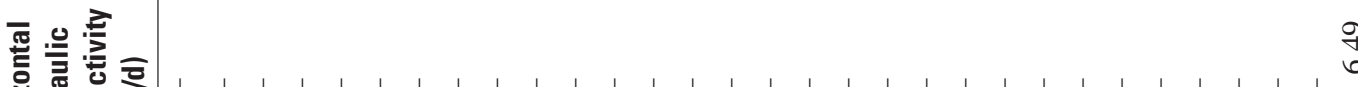

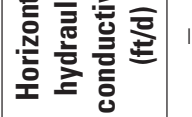
๑่

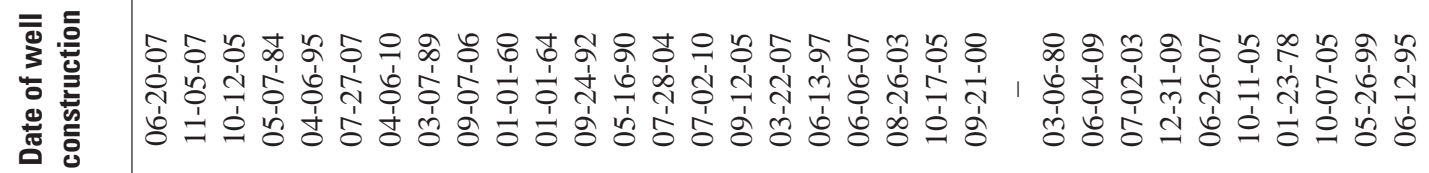

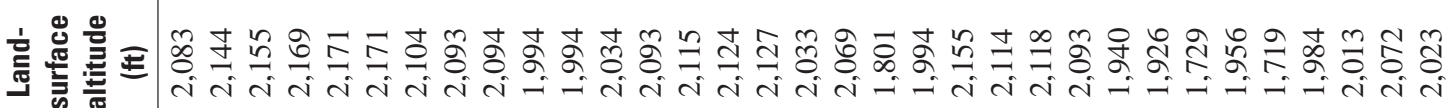

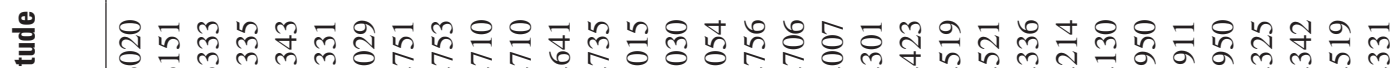
mm mెm

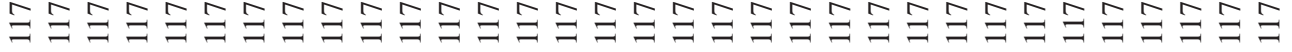
욜

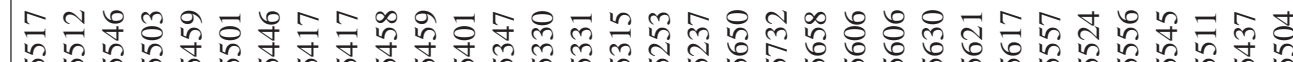

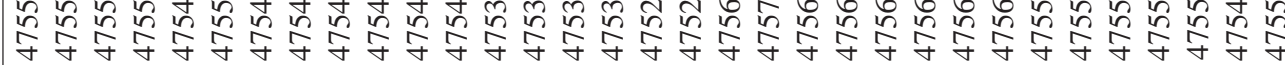

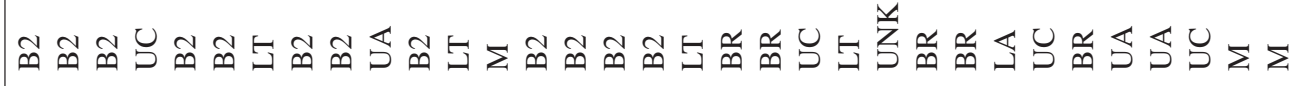

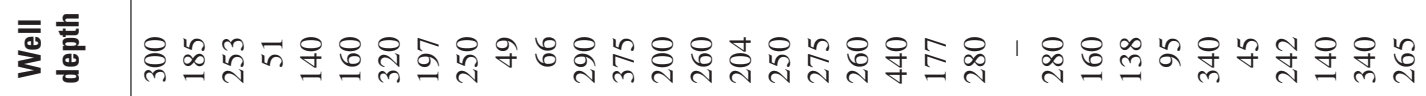

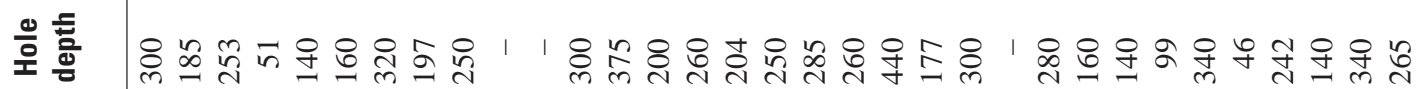
.

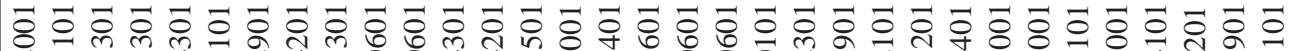
施 m

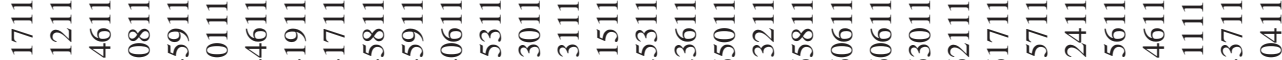

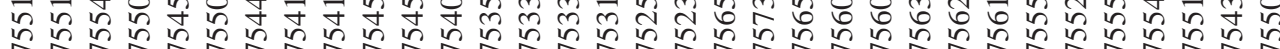

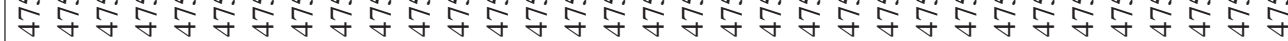

犗

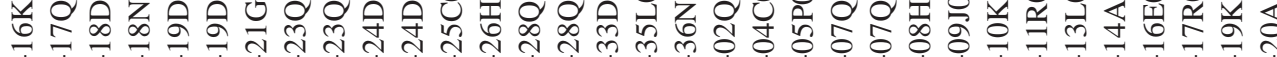

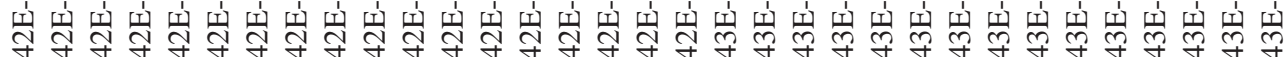

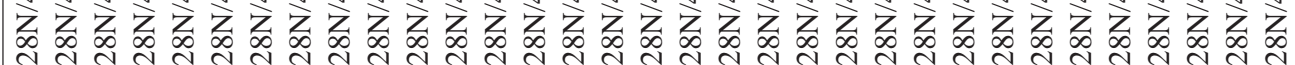




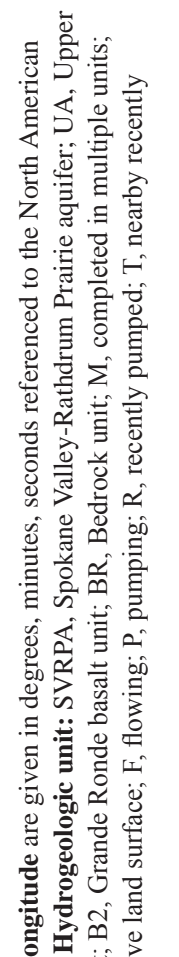

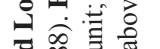

政 $\overline{8}$

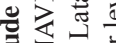

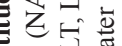

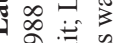

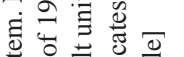

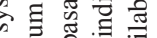

no

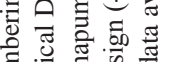

言焉设气 है क्षित

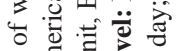

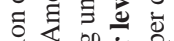

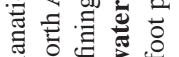

展

$0 \cong$ प⿺

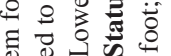

记

牙

象离寻

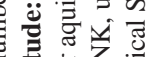

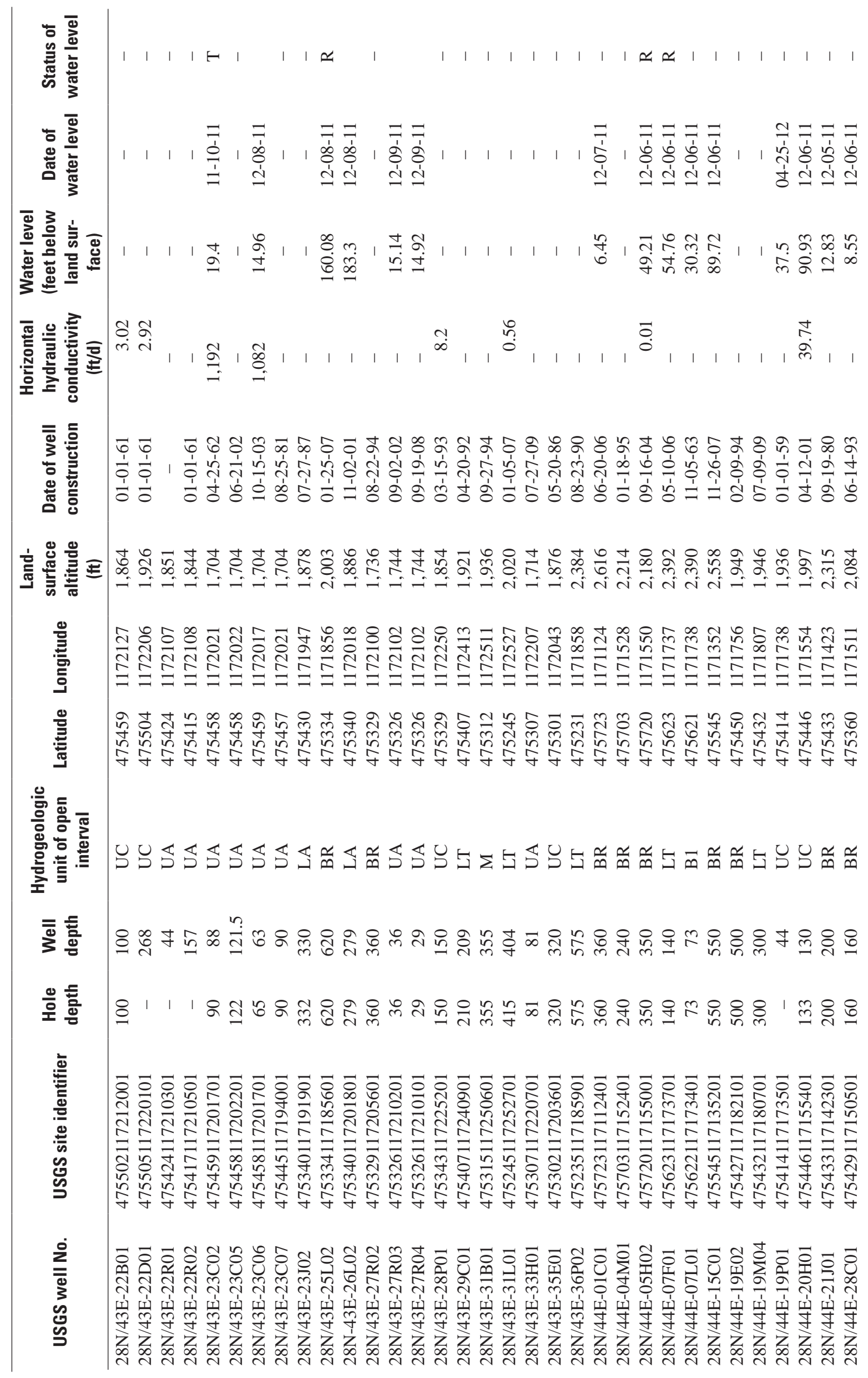



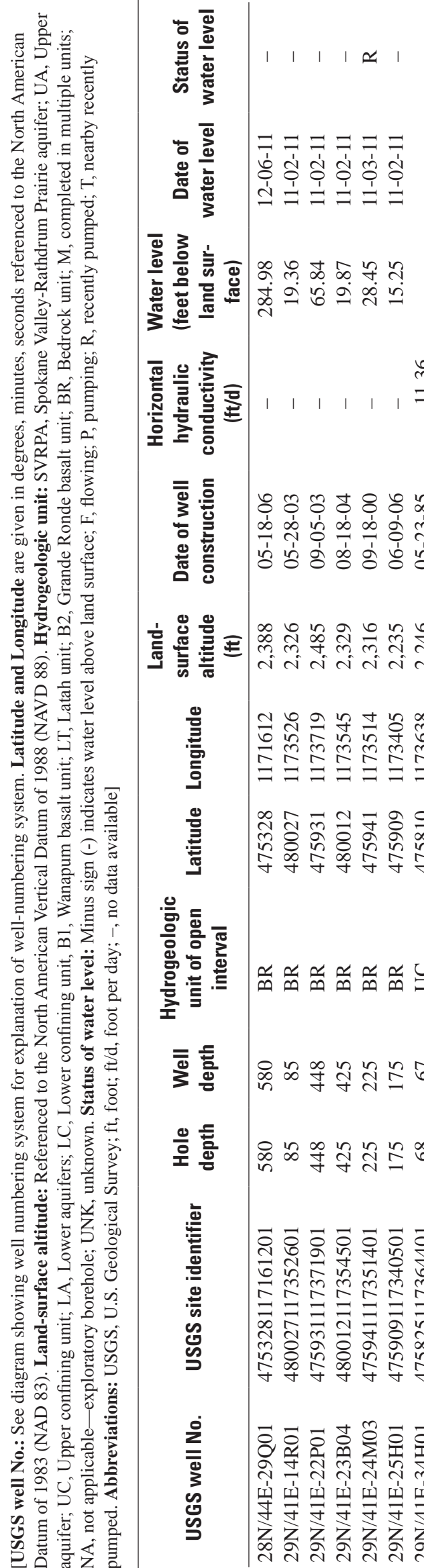

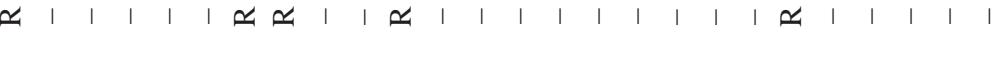

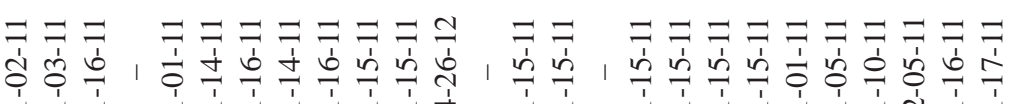

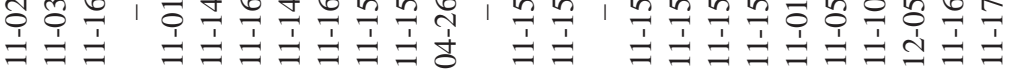

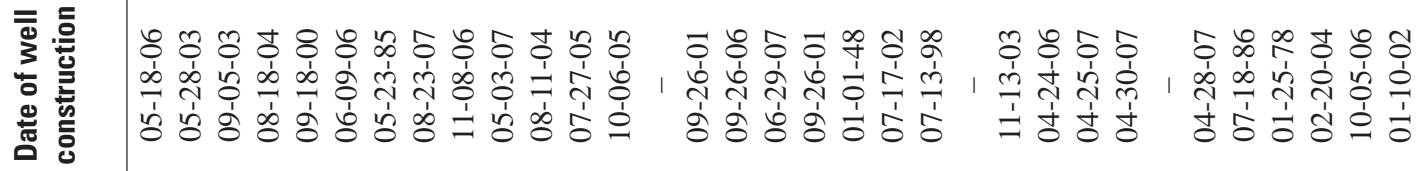

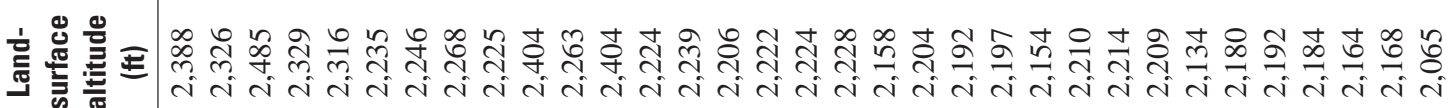

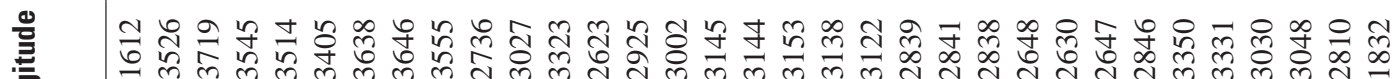
产

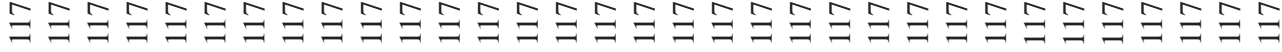
要

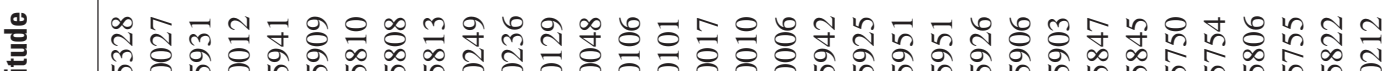

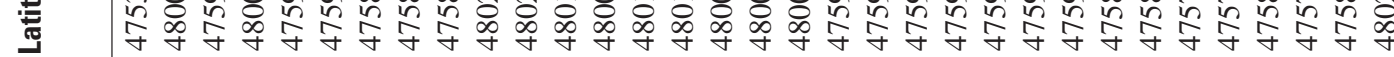

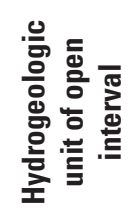

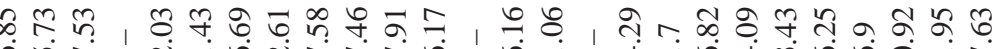

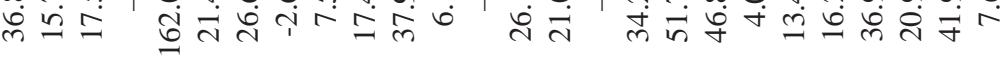
赵

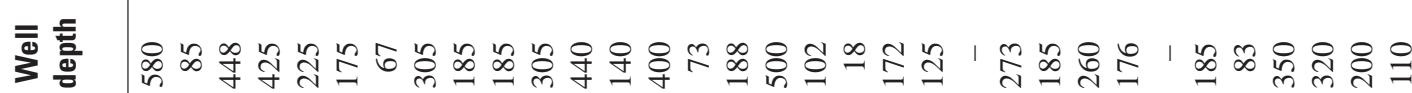

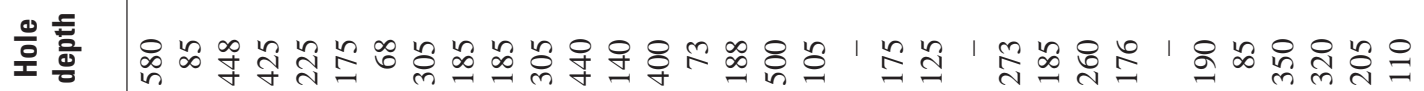

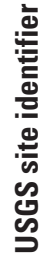

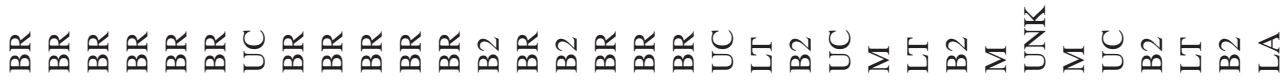

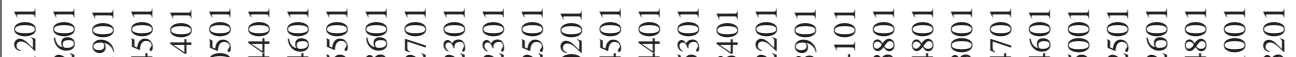

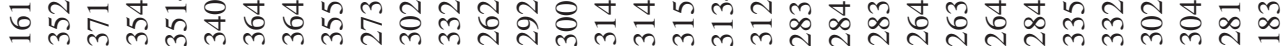

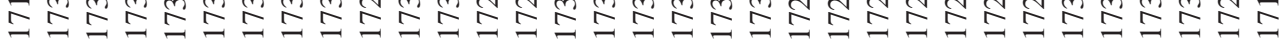

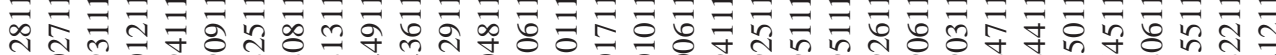

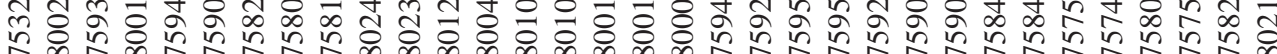

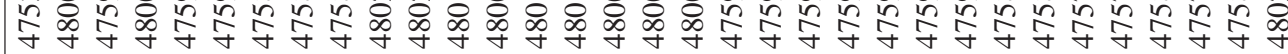

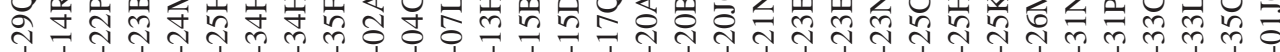

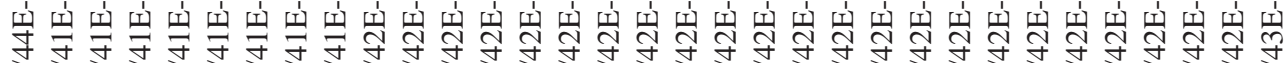

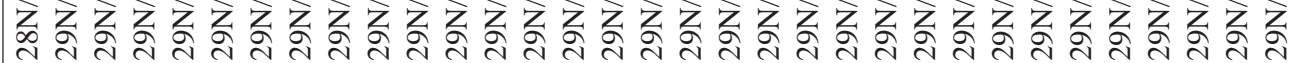




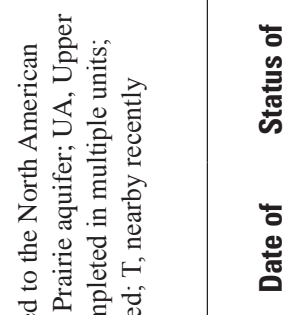

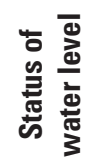

目

焉要方

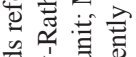

可高要

政

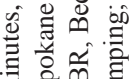

白的言

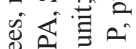

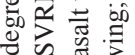

的政

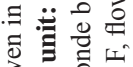

施

\%

ริ

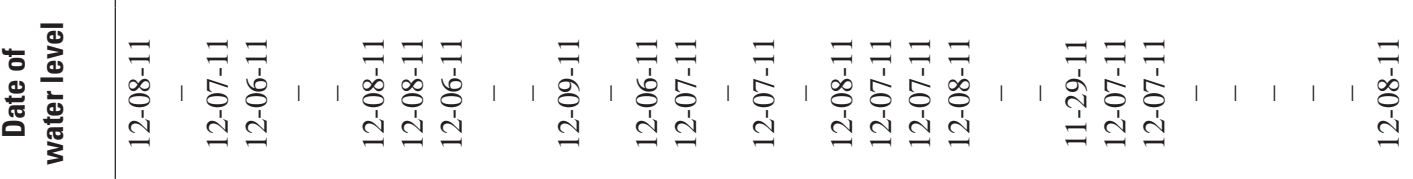

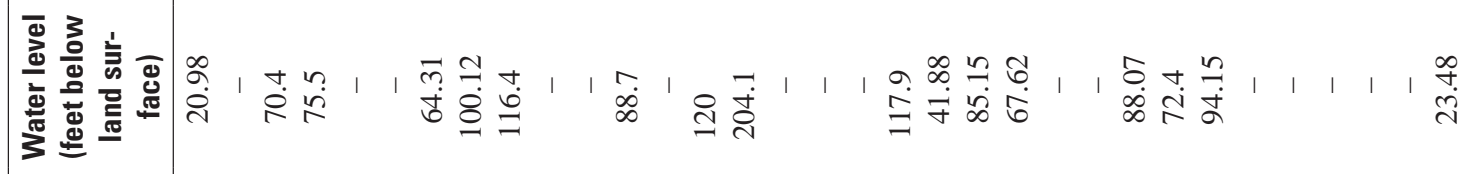

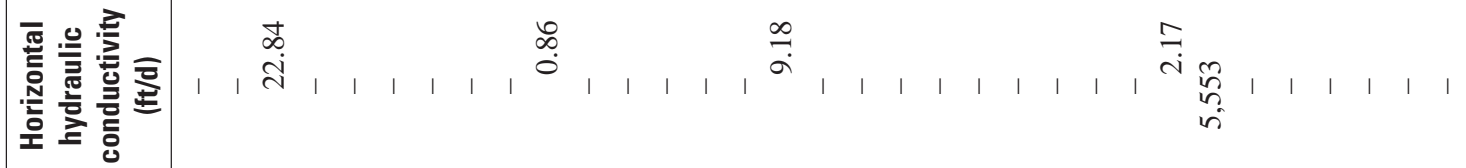

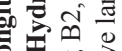

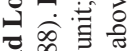

들

원

空

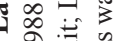

过吉焉

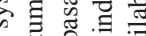

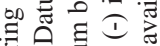

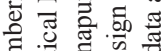

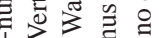

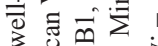

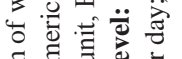

등

要要

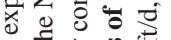

包苍是

要毛向

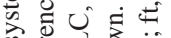

क के

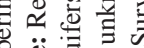

흄 च

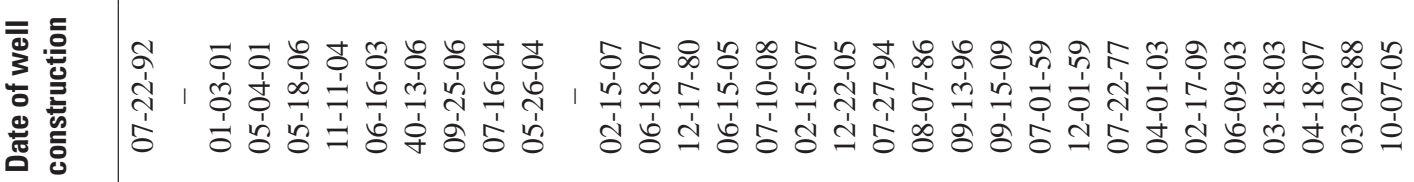

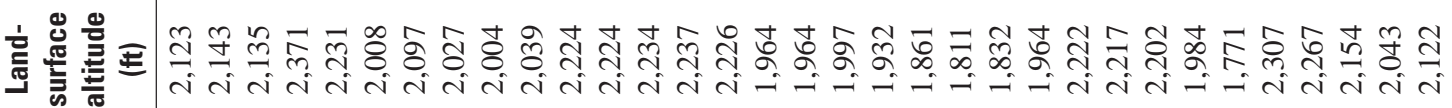

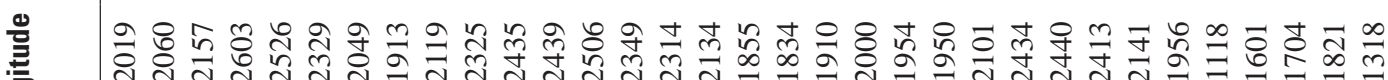

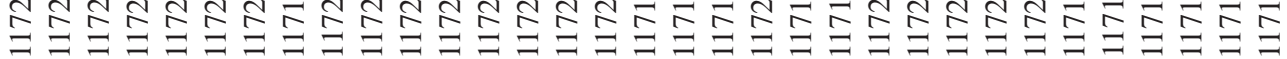

(1)

:

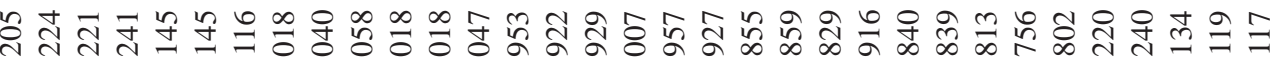

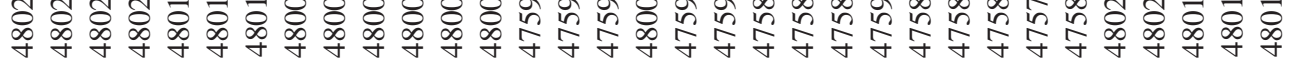

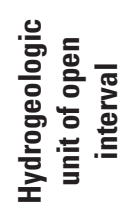

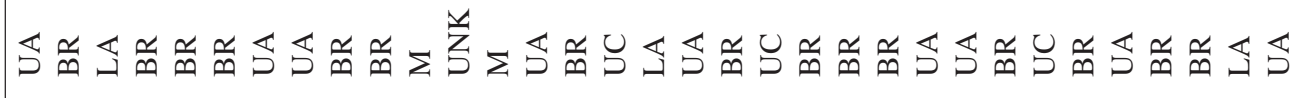

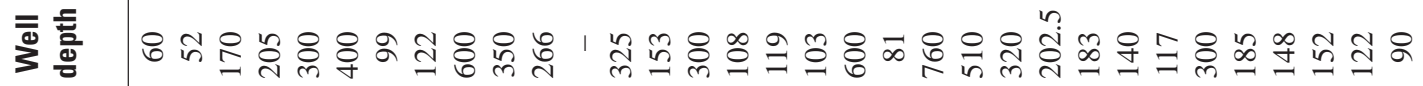

을 홓

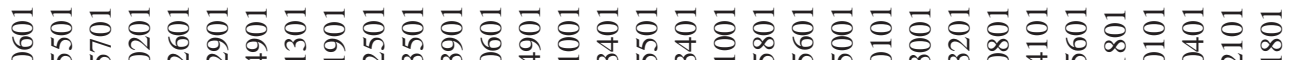

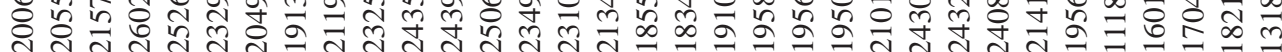

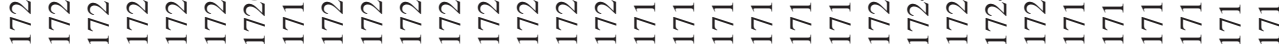

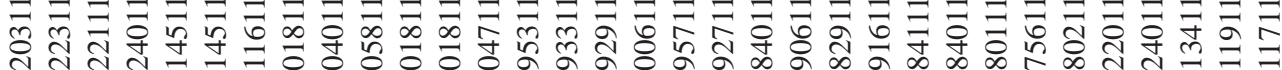

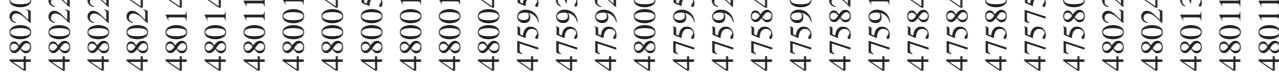



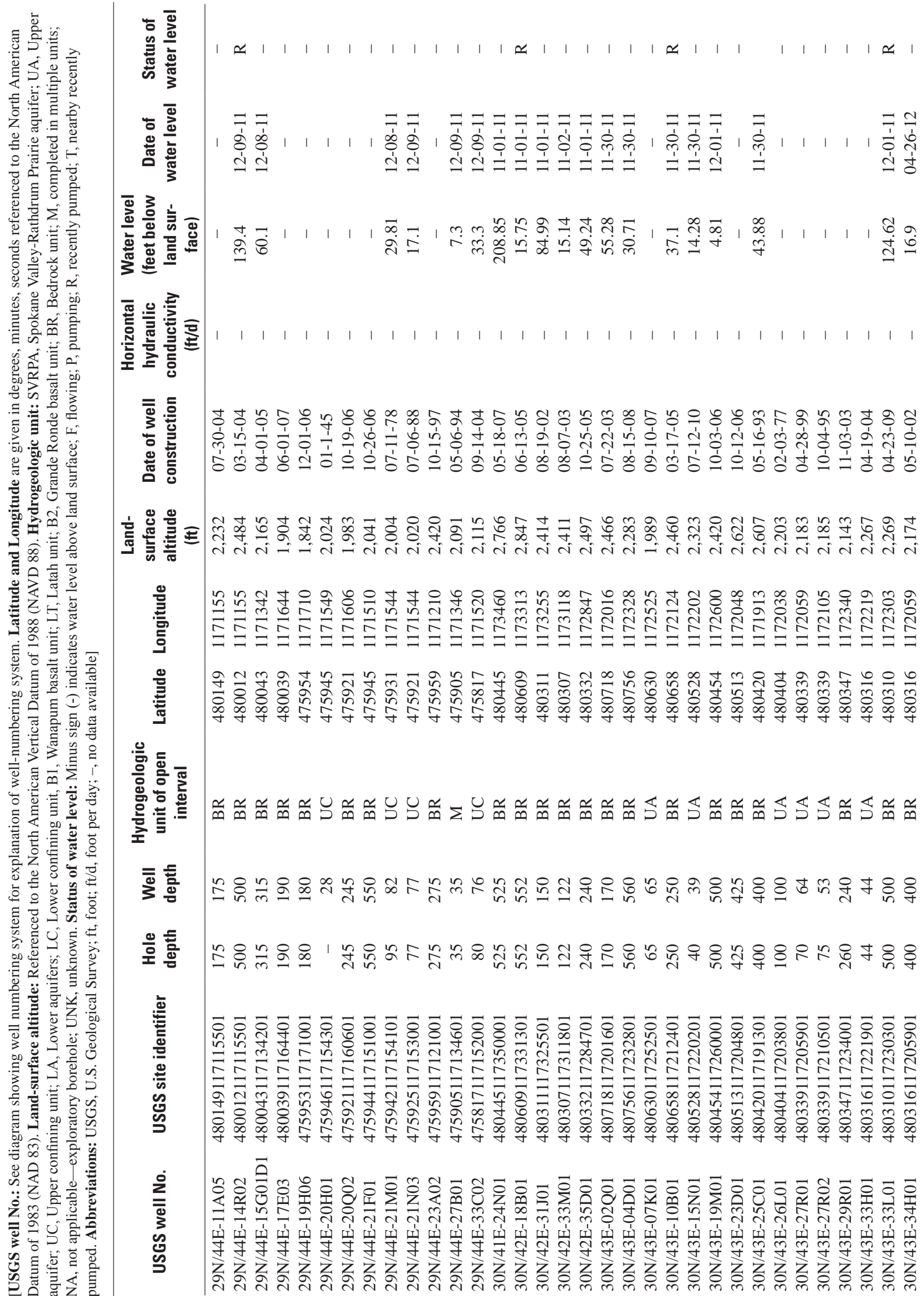


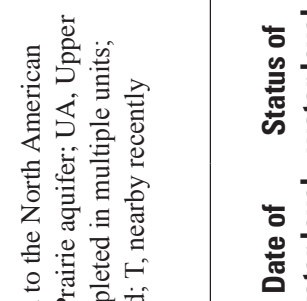

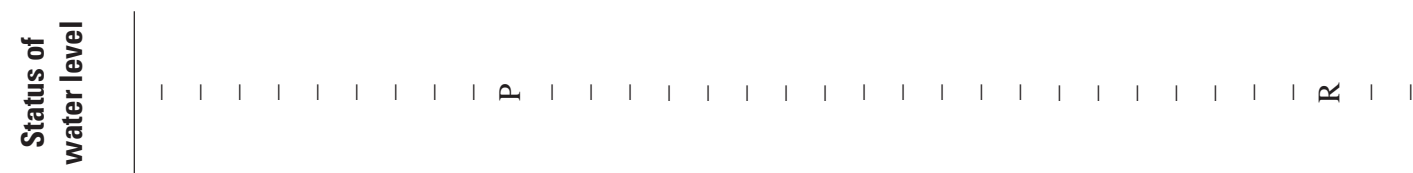

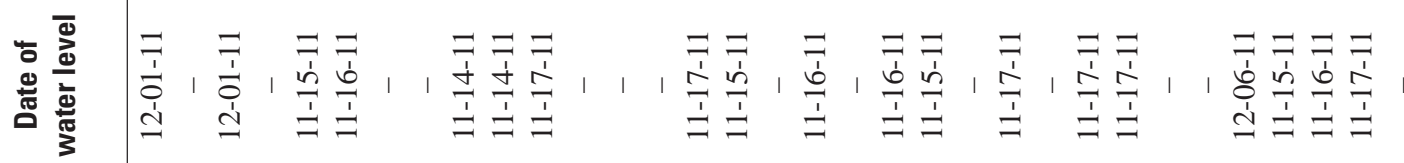

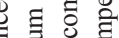

踪衣言

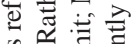

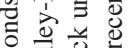

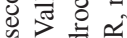

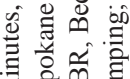

白的言

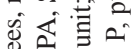

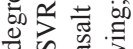

ton

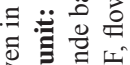

응

\% $\frac{1}{8}$ 巡

을

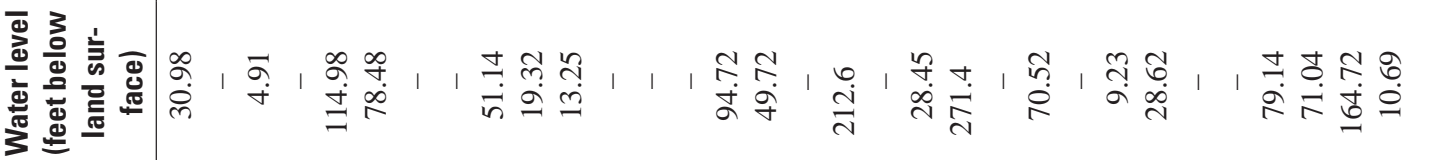

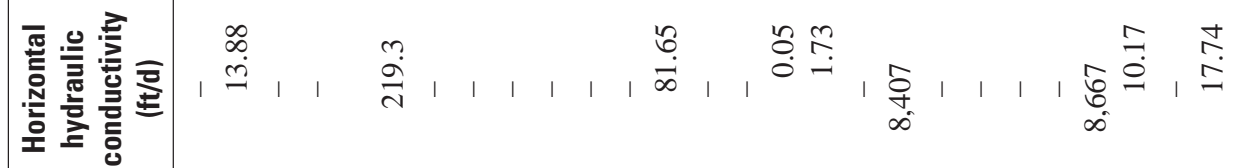

옹

4 昔

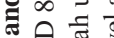

일

已戠

品

要考

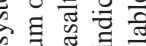

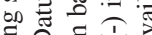

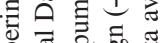

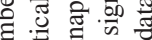

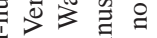

उ

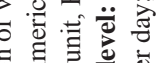

定安

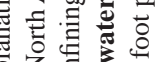

区欠

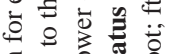

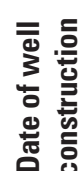

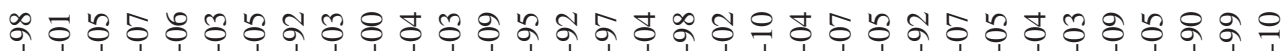

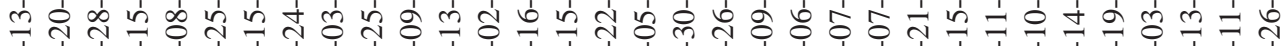

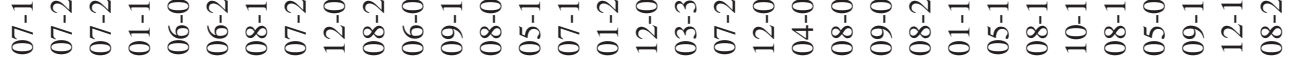

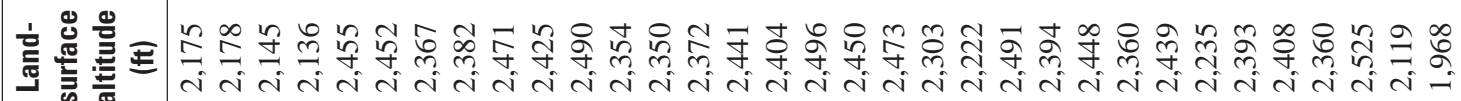

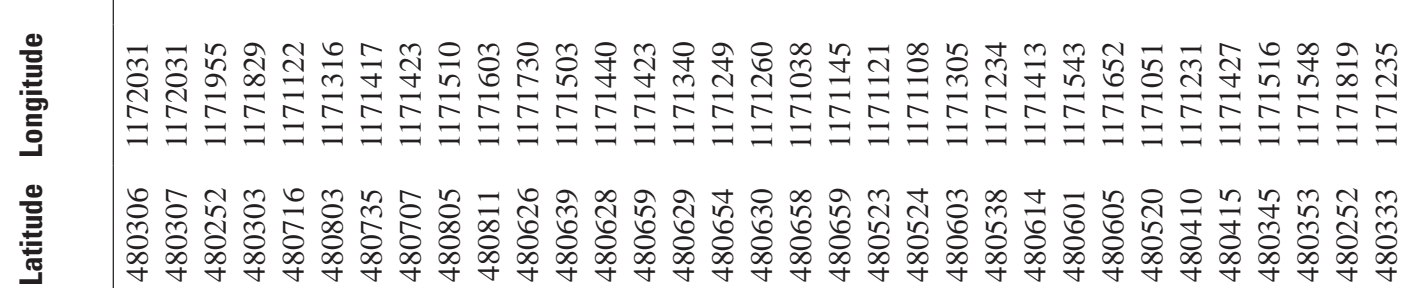

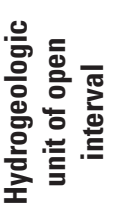

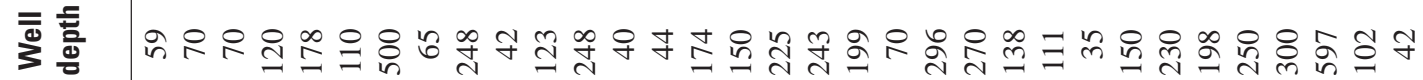

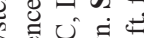

की

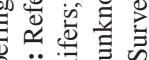

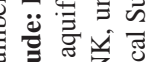

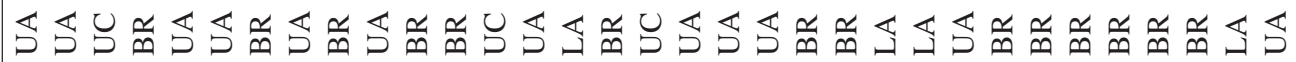

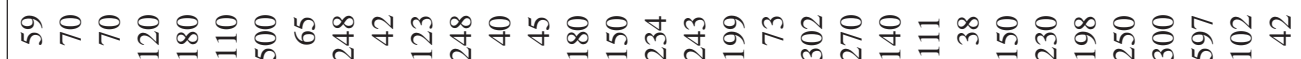

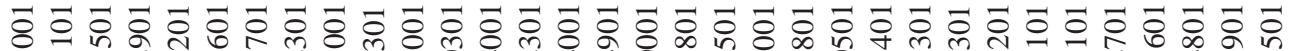

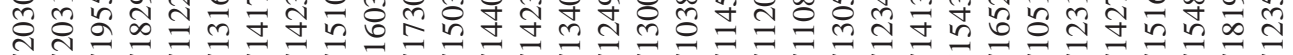

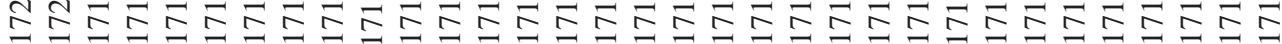

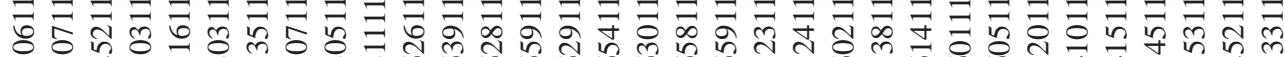

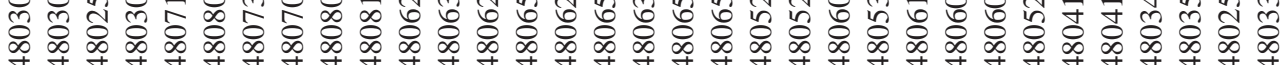

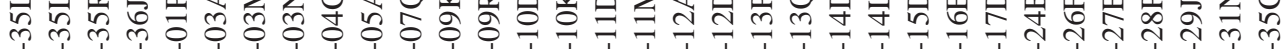

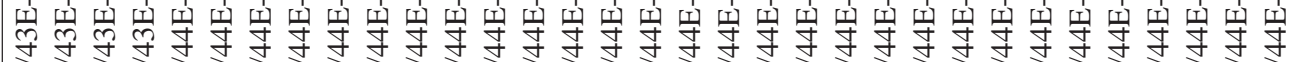

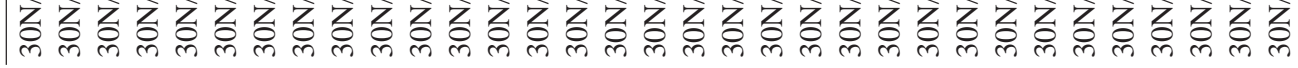



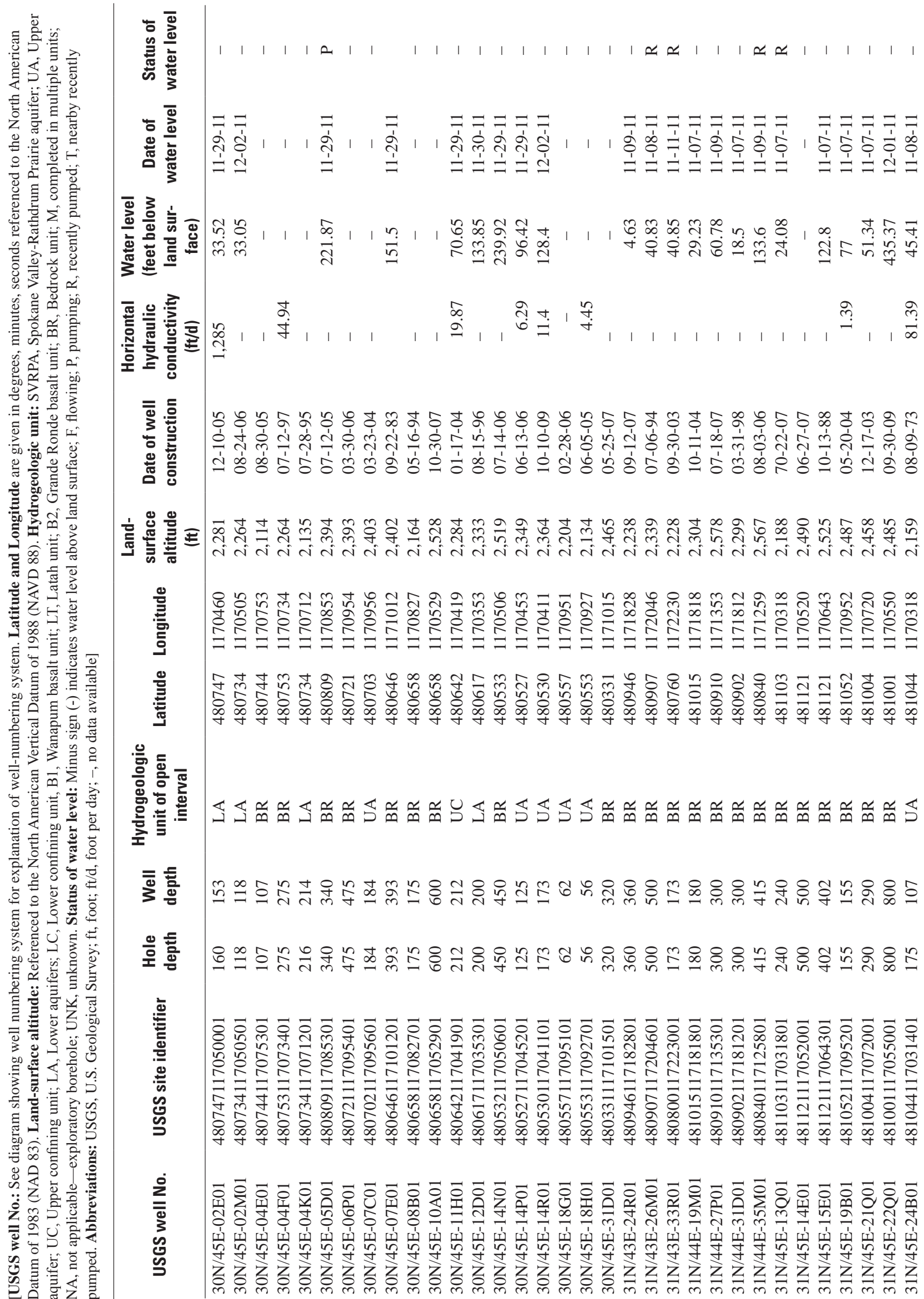

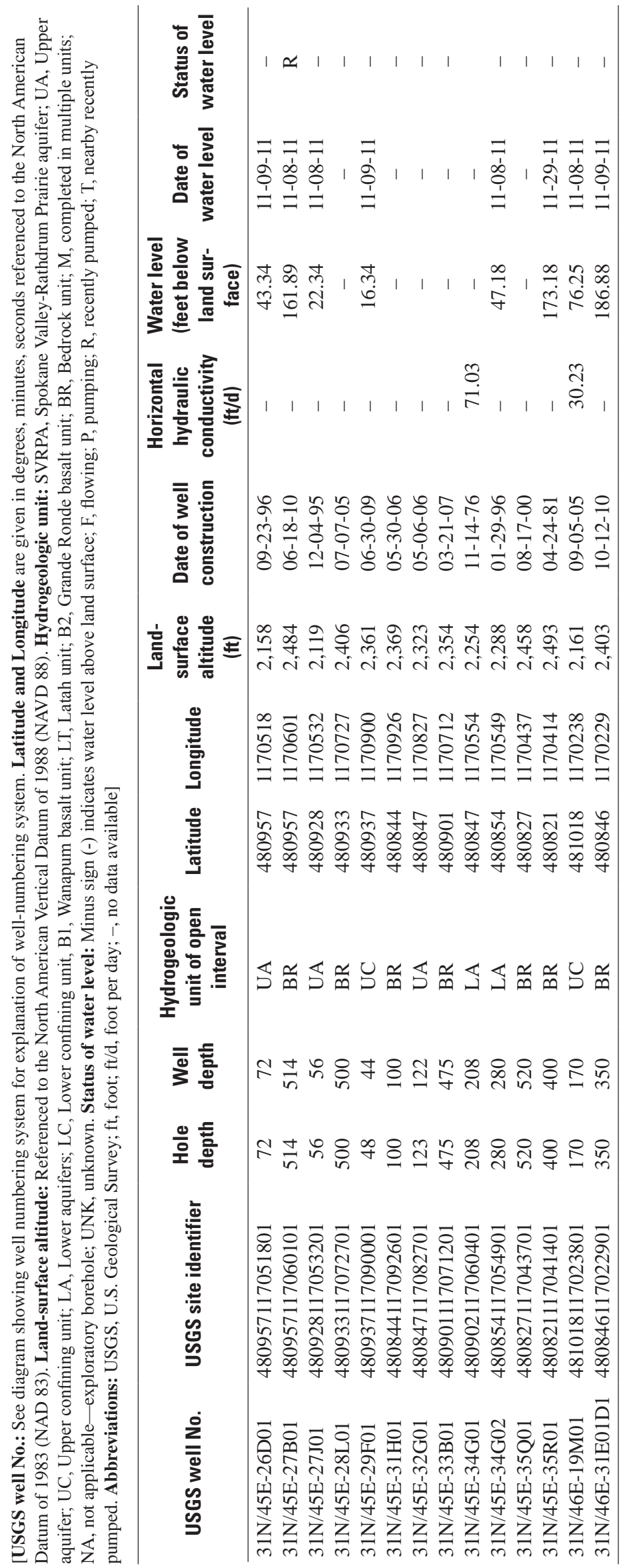


\section{Glossary}

Acre-foot (acre-ft): The volume of water needed to cover an acre of land to a depth of 1 foot (equivalent to 43,560 cubic feet or 325,851 gallons).

Alluvium: General term for sediments of gravel, sand, silt, clay, or other particulate rock material deposited by flowing water, usually in the beds of rivers and streams, on a flood plain, on a delta, or at the base of a mountain.

Aquifer: A geologic formation, group of formations, or part of a formation that contains sufficient saturated permeable material to yield significant quantities of water to springs and wells.

Bedrock: A general term used for solid rock that underlies soils or other unconsolidated material.

Confined aquifer (artesian aquifer): An aquifer that is completely filled with water under pressure and is overlain by material that restricts the movement of water.

Confining layer: A body of impermeable, or distinctly less permeable (see permeability), material that is stratigraphically adjacent to one or more aquifers that restricts the movement of water into and out of the aquifers.

Cubic foot per second ( $\mathbf{f t} / \mathbf{s}$, or cfs): Rate of water discharge representing a volume of 1 cubic foot passing a given point during 1 second, equivalent to approximately 7.48 gallons per second or 448.8 gallons per minute or 0.02832 cubic meter per second. In a stream channel, a discharge of 1 cubic foot per second is equal to the discharge at a rectangular cross section, 1 foot wide and 1 foot deep, flowing at an average velocity of 1 foot per second.

Discharge: The volume of fluid passing a point per unit of time, commonly expressed in cubic feet per second, million gallons per day, gallons per minute, or seconds per minute per day.
Drainage basin: The land area drained by a river or stream.

Drainage divide: The boundary between adjoining drainage basins.

Drawdown: The difference between the water level in a well before pumping and the water level in the well during pumping. Additionally, for flowing wells, the reduction of the pressure head as a result of the discharge of water.

Evaporation: The process by which water is changed to gas or vapor; occurs directly from water surfaces and from the soil.

Fluvial deposit: A sedimentary deposit consisting of material transported by suspension, or laid down by a river or stream.

Gaging station: A particular site on a stream, canal, lake, or reservoir where systematic observations of hydrologic data are obtained.

Glacial: Of or relating to the presence and activities of ice or glaciers.

Glacial drift: A general term for rock material transported by glaciers or icebergs and deposited directly on land or in the sea.

Glacial lake: A lake that derives its water, or much of its water, from the melting of glacial ice; also a lake that occupies a basin produced by glacial erosion.

Glacial outwash: Stratified detritus (chiefly sand and gravel) "washed out" from a glacier by meltwater streams and deposited in front of or beyond the end moraine or the margin of an active glacier.

Granite/Granitic rock: A coarse-grained igneous rock.

Groundwater: In the broadest sense, all subsurface water, commonly that part of the subsurface water in the saturated zone.

Groundwater flow system: The underground pathway by which groundwater moves from areas of recharge to areas of discharge. 
Headwaters: The source and upper part of a stream.

Hydraulic conductivity: The capacity of a rock to transmit water. It is expressed as the volume of water that will move in unit time under a unit hydraulic gradient through a unit area measured at right angles to the direction of flow.

Hydraulic head: The height of the free surface of a body of water above a given point beneath the surface.

Igneous rocks: Rocks that have solidified from molten or partly molten material.

Infiltration: The downward movement of water from the atmosphere into soil or porous rock.

Lacustrine: Pertaining to, produced by, or formed in a lake.

Lake stand: Temporary level of glacial lake lasting over a period of years.

Loess: Fine-grained deposit of wind-blown and wind-deposited silt and fine sand.

Long-term monitoring: The collection

of data over a period of years or

decades to assess changes in selected hydrologic conditions.

Median: The middle or central value in a distribution of data ranked in order of magnitude. The median is also known as the 50th percentile.

Metamorphic rocks: Rocks derived from preexisting rocks by mineralogical, chemical, or structural changes (essentially in a solid state) in response to marked changes in temperature, pressure, shearing stress, and chemical environment at depth in the Earth's crust.

Monitoring: Repeated observation, measurement, or sampling at a site, on a scheduled or event basis, for a particular purpose.

Moraine: A mound, ridge, or other distinct accumulation of unsorted, unstratified glacial drift, predominantly till, deposited chiefly by direct action of glacier ice.

Mouth: The place where a stream discharges to a larger stream, a lake, or the sea.
Permeability: The capacity of a rock for transmitting a fluid; a measure of the relative ease with which a porous medium can transmit a liquid.

Potentiometric surface: An imaginary surface that represents the total head in an aquifer. It represents the height above a datum plane at which the water level stands in tightly cased wells that penetrate the aquifer.

Precipitation: Any or all forms of water particles that fall from the atmosphere, such as rain, snow, hail, and sleet.

Recharge (groundwater): The process involved in the absorption and addition of water to the zone of saturation; also, the amount of water added.

Runoff: That part of precipitation or snowmelt that appears in streams or surfacewater bodies.

Sedimentary rocks: Rocks formed by the consolidation of loose sediment that has accumulated in layers.

Shale: A fine-grained sedimentary rock formed by the consolidation of clay, silt, or mud.

Siltstone: An indurated silt having the texture and composition of shale but lacking its fine lamination.

Spring: Place where a concentrated discharge of groundwater flows at the ground surface.

Streamflow: The discharge of water in a natural channel.

Surface water: An open body of water such as a lake, river, or stream.

Terminal moraine: The end moraine extending across a glacial plain or valley as an arcuate or crescent ridge that marks the farthest advance or maximum extent of a glacier.

Till: Predominantly unsorted and unstratified drift, deposited directly by and underneath a glacier without subsequent reworking by meltwater, and consisting of a heterogeneous mixture of clay, silt, sand, gravel, and boulders. 
Transmissivity: The rate at which water is transmitted through a unit width of an aquifer under a unit hydraulic gradient. It equals the hydraulic conductivity multiplied by the aquifer thickness.

Tributary: A river or stream flowing into a larger river, stream, or lake.

Unconfined aquifer: An aquifer whose upper surface is a water table free to fluctuate under atmospheric pressure.
Unconsolidated deposit: Deposit of loosely bound sediment that typically fills topographically low areas.

Watershed: See drainage basin.

Water table: The top water surface of an unconfined aquifer at atmospheric pressure.

Withdrawal Water removed from the ground or diverted from a surface-water source for use. 
This page intentionally left blank. 
Publishing support provided by the U.S. Geological Survey

Publishing Network, Tacoma Publishing Service Center

For more information concerning the research in this report, contact the

Director, Washington Water Science Center

U.S. Geological Survey

934 Broadway, Suite 300

Tacoma, Washington 98402

http://wa.water.usgs.gov 
